FA
V. cop. 2

Field Columbian Museum

Publication 84.

Anthropological Series.

Vol. VI., No. 1.

\title{
THE ORÁIBI OÁQÖL CEREMONY
}

BY

H. R. Voti.

THE STANLEY MCCORMICK HÓPI EXPEDITION

\author{
George A. Dorsey
}

Curator, Department of Anthropology.

Chicago, U. S. A.

Decernber, 1903 



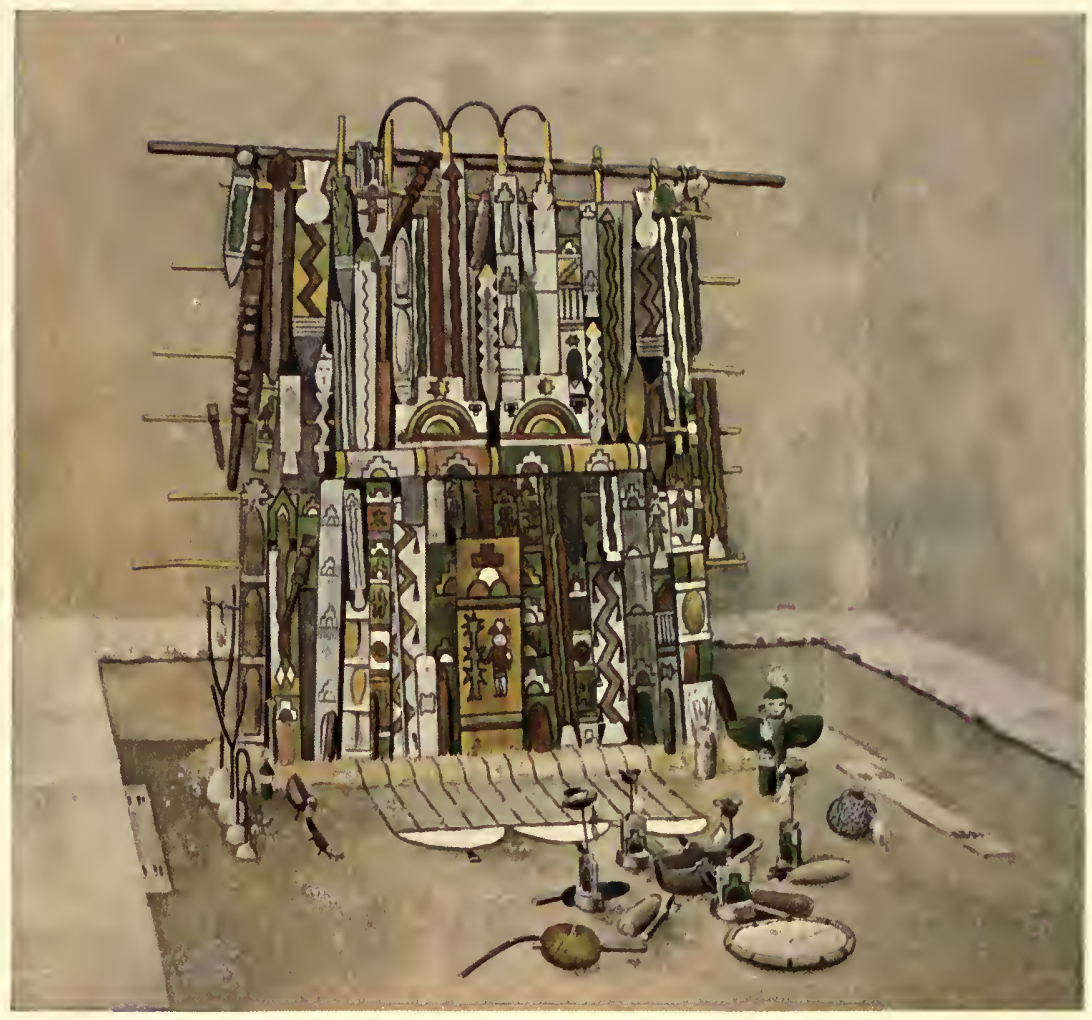




\section{Pl. I. (Frontispiece) the ó́qöl Altar.}

The altar shown in the plate is one that was reproduced by the author for the Field Columbian Museum. Though the Oáqöl altar is undoubtedly the latest altar introduced in Oráibi, it is certainly one of the most elaborate Hópi altars known to the author. It consists of about eighty-three slabs and sticks, which are fastened to a reed framework, and a number of objects that are placed in front of the upright framework. In the center of the latter, on a wide slab, may be seen a drawing of Múyingwa, the God of Germination, who holds in his hand a growing corn-stalk. Over both is a picture of clouds, and beneath the symbol of the rainbow. To the left of this slab stands the short, white one, on which is drawn, on one side, the figure of the sun, on the reverse side that of the moon. On a number of slabs symbols of clouds, lightning, corn-ears, rainbows, etc., are easily recognized.

On the floor are three cloud symbols in black outlines, the semi-circles being filled with corn meal. From them run black lines, representing rain, to the sand ridge. To the right side of this drawing stands, with extended wings, a figurine of Oáqöl-Mana, in front of it one of Oáqöl-Tiyo, a second one like it standing at the left end of the sand ridge. To the left and somewhat behind the Oáqöl-Mana is seen the tiponi of the chief priestess, and in front of it the netted gourd vessel in which she gets the water for the ceremonies. On the left side of the altar stand, in two clay pedestals, crooks, the symbol of life; in two others, forked sticks, to which are fastened little birds. Close to it two wooden birds, one representing a wild duck; the other, some other water-fowl (the báchiro).

In front of the cloud drawing stands the medicine bowl, and around it are six ears of corn, and four wooden cloud symbols on which are mounted small wooden birds (some say they represent butterflies). In the extreme foreground stands a tray with sacred meal. To the left of this may be seen a gourd rattle, and by the side of this, partly hidden from view, the mósilili, a short, bent stick, to which are fastened a few tent shells. 


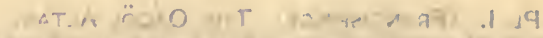

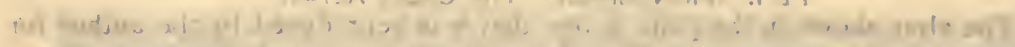

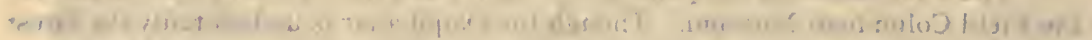

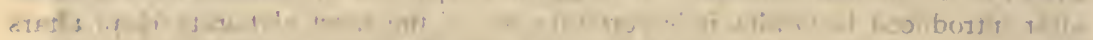

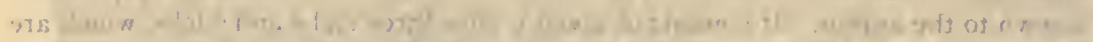

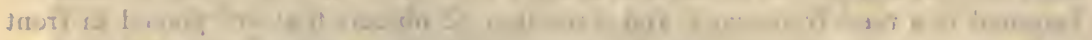

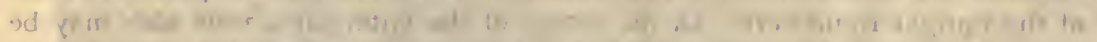

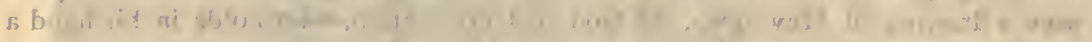

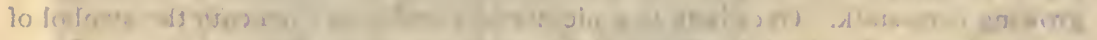

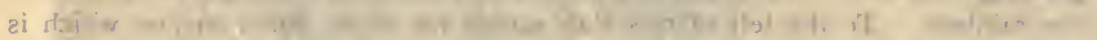

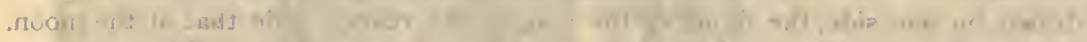

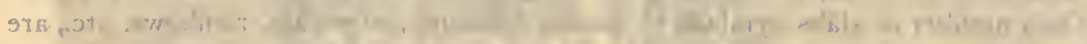

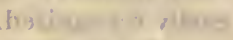

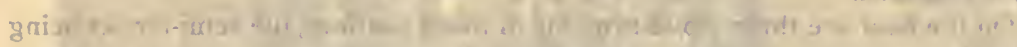

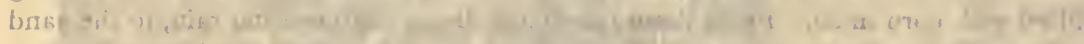

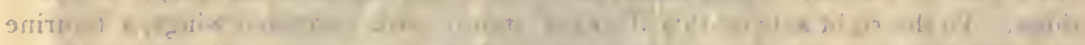

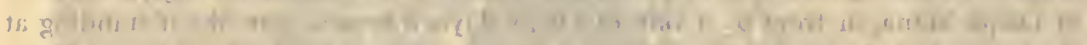
susto

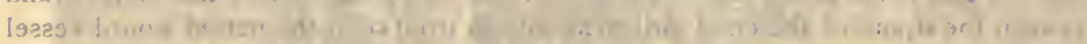

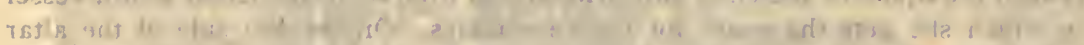

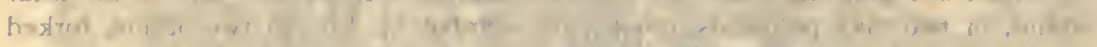

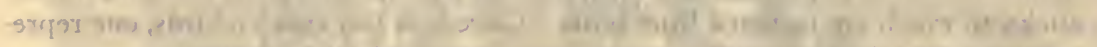

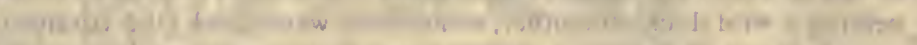

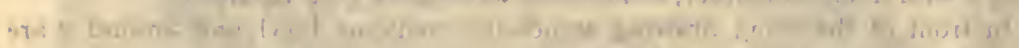

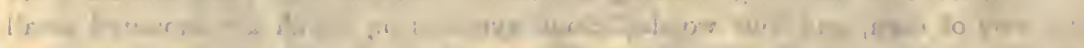

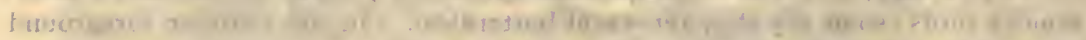

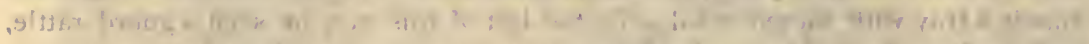

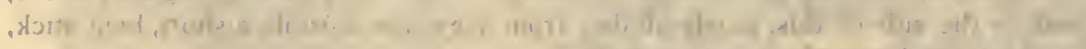

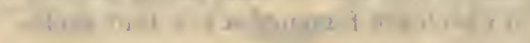




\title{
Field Columbian Museum
}

Publication 84.

Anthropological Series.

VOL. VI., No.I.

\section{THE ORÁIBI OÁQÖL CEREMONY}

BY

\author{
H. R. Voth. \\ THE LIBRARY OF THE \\ FEB 171938 \\ UNIVERSITY OF ILLINOIS
}

THE STANLEY MCCORMICK HÓPI EXPEDITION

George A. Dorsey

Curator, Department of Anthropology.

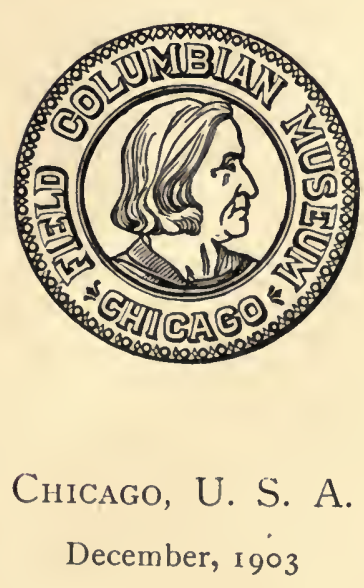





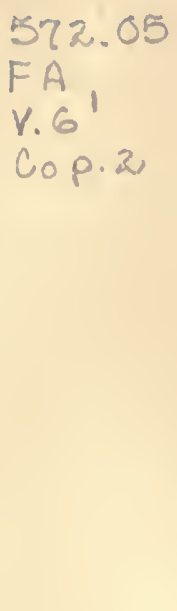

THE ORÁIBI OÁQÖL CEREMONY BY

H. R. Vотн 



\section{CONTENTS.}

Note.

Introduction

Participants and their Clan Relationship

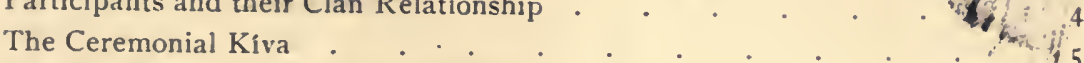

Time and Duration of the Celebration . . . . . . . . . 6

Preliminary Ceremony . . . . . . . . . . . . . . 7

The Nine-Day Ceremony . . . . . . . . . . . . . 9

First Day . . . . . . . . . . . . 9

Second Day . . . . . . . . . . . . 16

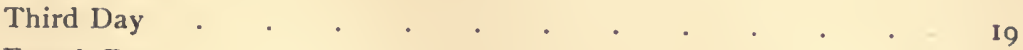

Fourth Day . . . . . . . . . . . . 19

Fifth Day . . . . . . . . . . . . 22

Sixth Day . . . . . . . . . . . 3 I

Seventh Day . . . . . . . . . . . 32

Eighth Day . . . . . . . . . . . 34

Ninth Day . . . . . . . . . . . 38 



\section{NOTE.}

The report herewith presented on the "Oráibi Oáqöl Ceremony," by the Rev. H. R. Voth, is a continuation of a series of papers, the first of which was devoted to the Soyál Ceremony. Researches among the Hópi, with the view of the preparation of these reports, and of enlarging and making more complete the Hópi collections in this Institution, are now being carried on, as they have been in the past, by Mr. Voth, through the generosity of Mr. Stanley McCormick.

George A. Dorsey,

Curator of Anthropology.

Снicago, December 1, 1903. 



\section{LIST́ OF ILLUSTRATIONS.}

Plate.

I. Oáqöl Altar (colored) - _ _ _ _ _ Frontispiece

11. No. I, Masátoiniwa; No. 2, Qöyángösi - 3

III. No. I, The Hawíovi Kíva; No. 2, The Home of the Kél-Nyamu

(Sparrow-hawk clan)

IV. No. I, Lóloloma; No. 2, Lománkwa - . - - - 7

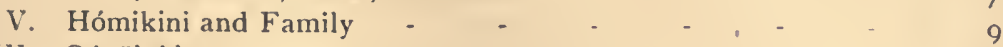

VI. Oáqöl Altar - $\quad$ - $\quad$ - $\quad$ - $\quad$ - $\quad$ - $\quad$ - 10

VII. Various Ceremonial Objects _ _ _ _ _ _ _ $\quad$ - 12

VIII. Chief Priestess Waiting to be Discharmed - _ $\quad$ - 12

IX. The Nátsi - $\quad$ - $\quad$ - $\quad$ - $\quad$ - $\quad$ - $\quad$ - $\quad$ - 19

X. The Tríili - $\quad$ - $\quad$ - $\quad \ldots \quad$ - $\quad 23$

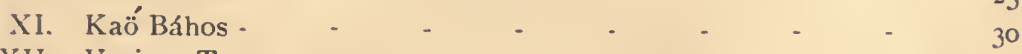

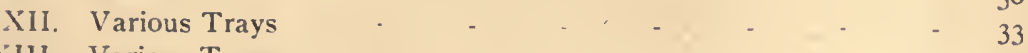

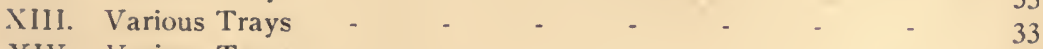

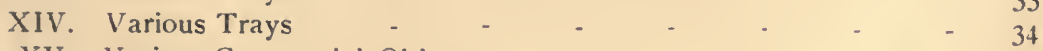

XV. Various Ceremonial Objects - _ _ _ _ _ _ $\quad 35$

XVI. Women Making Trays - _ _ _ _ _ _ $\quad$ - $\quad 36$

XVII. A Hópi Race -

XVIll. An Oáqöl-Mana - - $\quad$ - $\quad$ - $\quad$ - $\quad$ - 4

XIX. No. I, The Women Proceeding to the Plaza; No. 2, The Chief Priest Returning with the Medicine Bowl - - - $\$ 2$

XX. Oáqöl-Manas Going to the Plaza - _ _ . - 42

XXI. 'The Dance - - $\quad$ - $\quad$ - $\quad$ - $\quad$ - 43

XXIl. Waiting for the Prize to Descend - - - - $\quad$ - 43

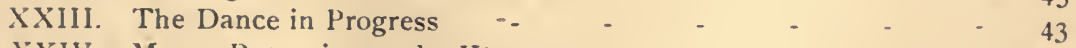

XXIV. Manas Returning to the Kiva - $\quad$ - $\quad$ - 43

XXV. The Dancers Returning to the Kiva _ _ _ _ _ $\quad 4 \quad 43$

XXVI. Contesting One of the Prizes - . - . - . 4

XXVII. The Prize Contest in Full Sway - - _ - . $\quad 45$

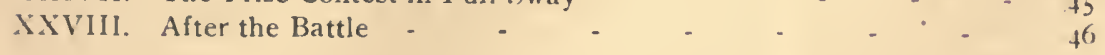



THE LIBRARY

OF THE

"UNIVERSITY OF ILLINOI: 

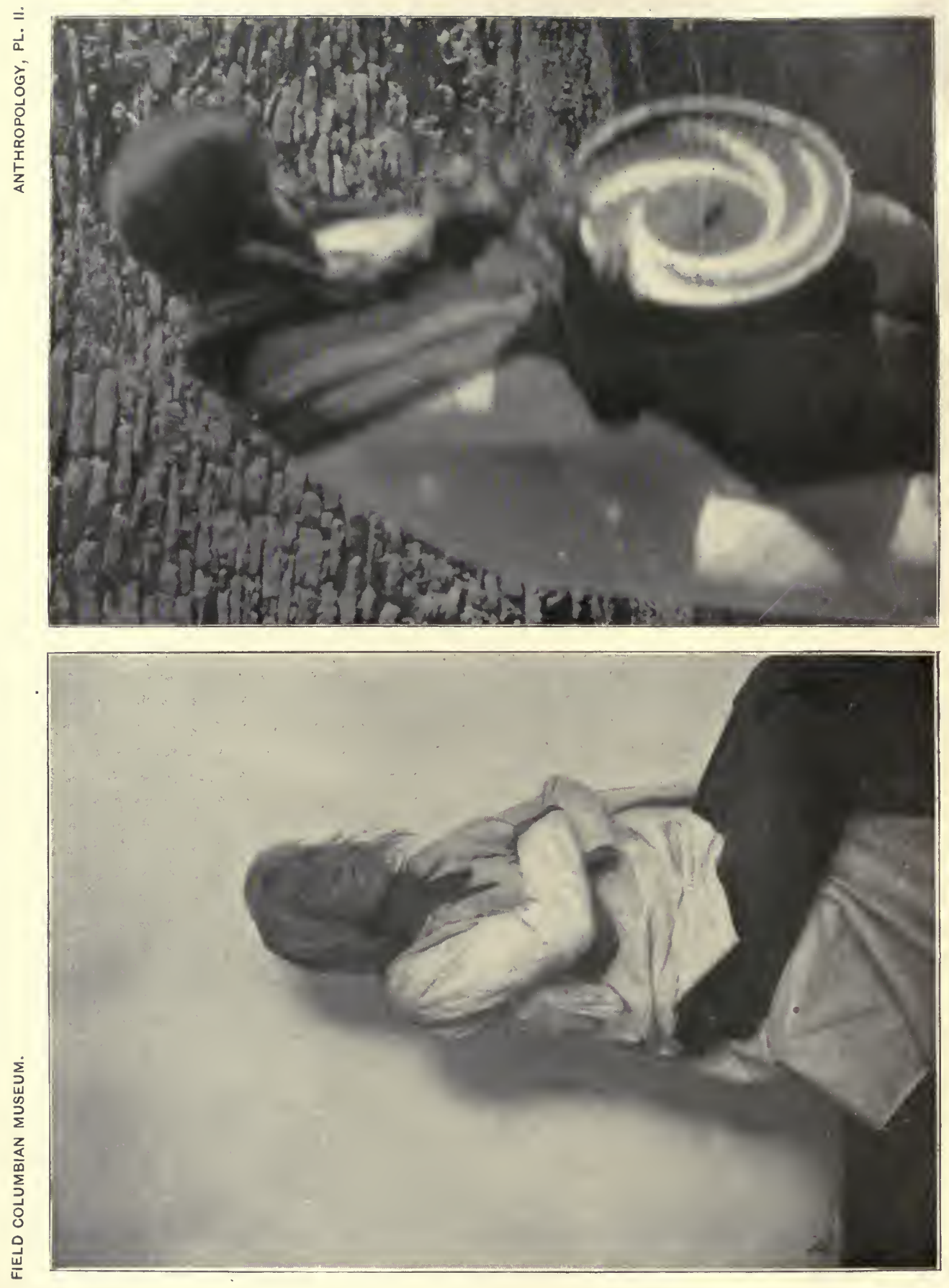
PL. II.

No. I. Masátoiniwa. The chief male priest of the Oáqöl Society.

No. 2. Qöyangösi. Chief Priestess of the Oáqöl Society.

The plate shows the priestess as she heads the line of dancers going to and returning from the dancing plaza. The somewhat imperfect negative had to be used and enlarged, as a negative showing the priestess to a better advantage was unfortunately lost. 


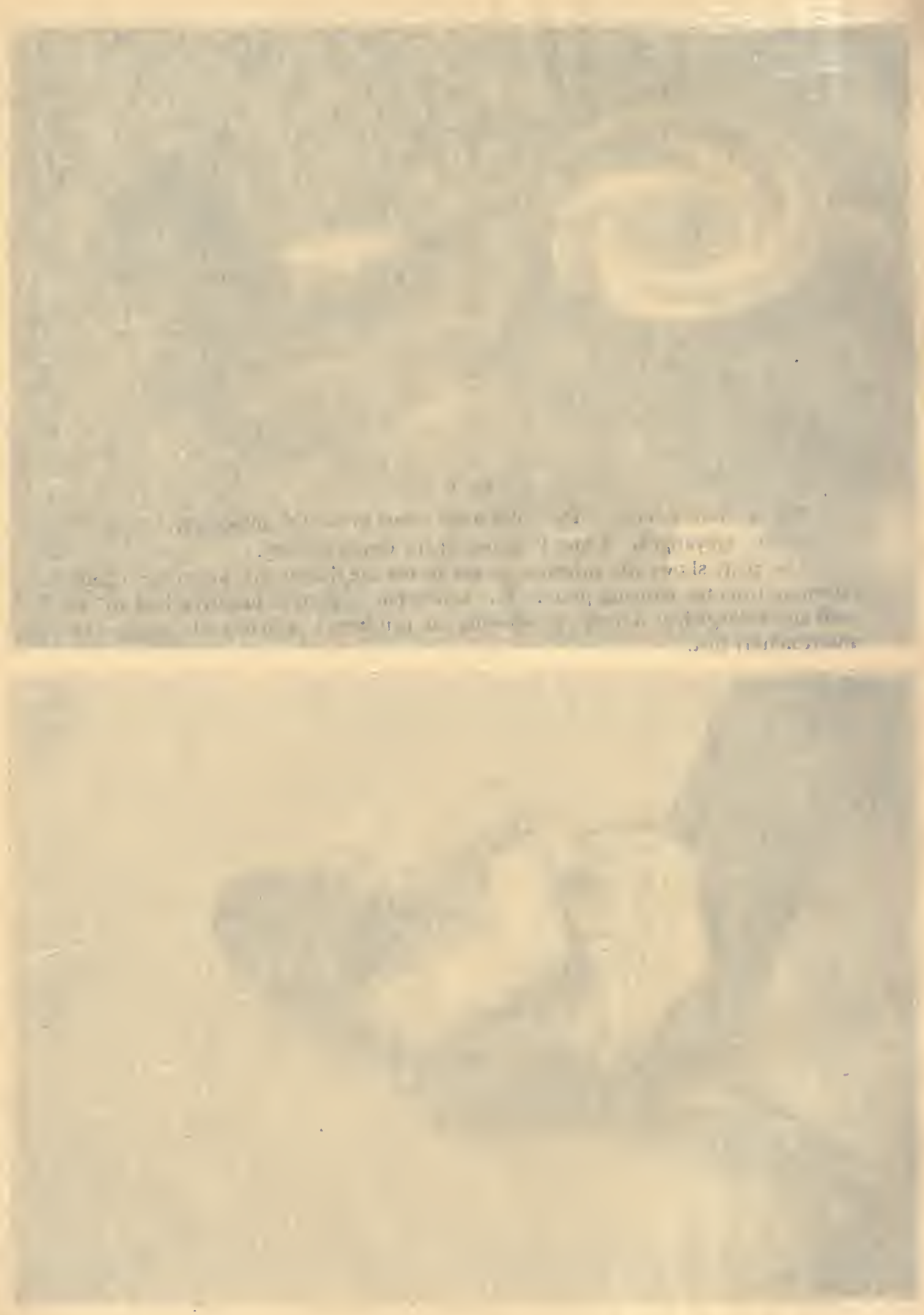




\section{INTRODUCTION.}

One of the three Women's Fraternities in the village of Oraibi is the Oáqöl Society, which, though the latest or youngest, is the largest of the religious orders in that village. Its leaders, and most of its members, belong to the Sand clan. There seems to be no doubt that this cult was introduced to the present Hópi villages from Aoátovi (Bow-Heights), once a thriving village twelve or fourteen miles southeast from Walpi. When this village was destroyed and most of the male inhabitants killed, nearly two hundred years ago, most of the women and children were distributed among the villages. One woman is said to have carried with her to the village of Mishóngnovi the tiponi and the altar of this Fraternity, thus introducing the Oáqöl cult in that village. ${ }^{1}$ After the.cult had flourished a while in this village -just how long cannot be ascertained-an Oráibi woman by the name of Shákletsnöma, of the Sand clan, married a man from Mishóngnovi named Hóka. They lived in the last named village, where the woman joined the Oáqöl Society, and thus became acquainted with the cult. Later this woman is said to have moved to Oráibi, where she taught the cult to another woman by the name of Kélwuhti, who also belonged to the Sand clan. These two women, tradition has it, made the first altar and introduced this cult in Oráibi. Kélwuhti became the first chief priestess, and when she died Shákletsnöma succeeded her. When the latter died a woman named Qöyáyaonöma assumed the position of chief Oáqöl priestess, a man named Chóchongo being chief, and Lomángöwa ${ }^{2}$ assistant priest. She was succeeded by her grandchild Qöyángösi, the present incumbent, who is now also about sixty or sixtyfive years old. Qöyáyaonöma was the mother of the present Oáqöl chief priest, Masátoiniwa (see No. I, PI. II), who is the uncle of Qöyángösi. (See No. 2, Pl. II.) It should be remembered that every Hópi Women's society has a chief priest and a chief priestess. As will be seen in the following pages, the functions of the two seem to be coordinate and mutual rather than otherwise, as far as the ceremony

2. Whether the woman took the altar with her at the time of the catastrophe tradition does not say. But it is reasonable to suppose-and the Indians are of the same opinion-that the village and what it contained was by no means totally destroyed, that for some time after objects were gotten from the deserted village, and that the priestesses of the Oáqöl Society went and saved from destruction the highly treasured paraphernalia of their sacred cult.

2 Lomảngöwa, who is still living, continued to act under Masatoiniwa until the split between the conservative and liberal Oráibis occurred, when he ceased to participate and the present assist. ant, Hómikinı, was initiated. 
4 Field Columbian Museum-Anthropology, Vol. Vi., No. I.

generally is concerned. In some special rites the otfice of the chief priest seems to predominate, in others that of the priestess. But in a general way the latter seems to be really the head of the order.

\section{PARTICIPANTS AND THEIR CLAN RELATIONSHIP.}

I. Qöyángösi, chief priestess

2. Masátoiniwa, chief priest

3. Hómikini, assistant priest

4. Talásngainöma

5. Qótchainöma

6. Möcínömka

7. Naǩwáyeshnöma

8. Sikáhtaimana

9. Pawónyeshnöma

ro. Polímana

I I. Kiwánıönöma

I 2. Nakwámösi

I3. Macáhoinöma

14. Tūwángönsi

15. Kárzhmönöma

16. Kwánhoinồma

17. Qöyáyeshnöma

I8. Nacílāwi

19. Tawángyamci

20. Yéshiwa (male)

21. Tūwámösi

22. Siḱángyaonöma

23. Homímöci

24. Macáhongnöma

25. Sikávenka

26. Tūwángönöma

27. Homíkwapnöma

28. Homívenci

29. Nūwáhongnöma

30. Homíyonci

3I. Kiwányeshnöma

32. Homíhoinöma

33. Tobéhmana

34. Tawángyaonöma

35. Pacháwamana

36. Homínömsi
Tūwá (Sand) clan.

'Tūwá (Sand) clan.

Kúkuts (Lizard) clan.

Tư wá (Sand) clan.

'Tũwá (Sand) clan.

'Tũwá (Sand) clan.

Tũwá (Sand) clan.

Tūwá (Sancl) clan.

Tũwá (Sand) clan.

Tūwá (Sand) clan.

Tũwá (Sand) clan.

Íshawuu (Coyote) clan.

Íshawuu (Coyote) clan.

Íshawuu (Coyote) clan.

İshawuu (Coyote) clan.

Íshawuu (Coyote) clan.

(Shìwáhpi) clan.

Píhkash (Young-Corn-Ear) clan.

Píhkash (Young-Corn-Ear) clan.

Píhkash (Young-Corn-Ear) clan.

Atók (Crane) clan.

Atók (Crane) clan.

Atók (Crane) clan.

Pákab (Reed) clan.

Pákab (Reed) clan.

Pákab (Reed) clan.

Pákab (Reed) clan.

Pákab (Reed) clan.

Pákab (Reed) clan.

Kwan (Agave) clan.

Kwan (Agave) clan.

Kwan (Agave) clan.

Kwan (Agave) clan.

Kwan (Agave) clan.

Kwan (Agave) clan.

Kárro (Parrot) clan. 


\section{THE LIBRARY}

OF THE

UNIVERSITY OF ILLINOI 

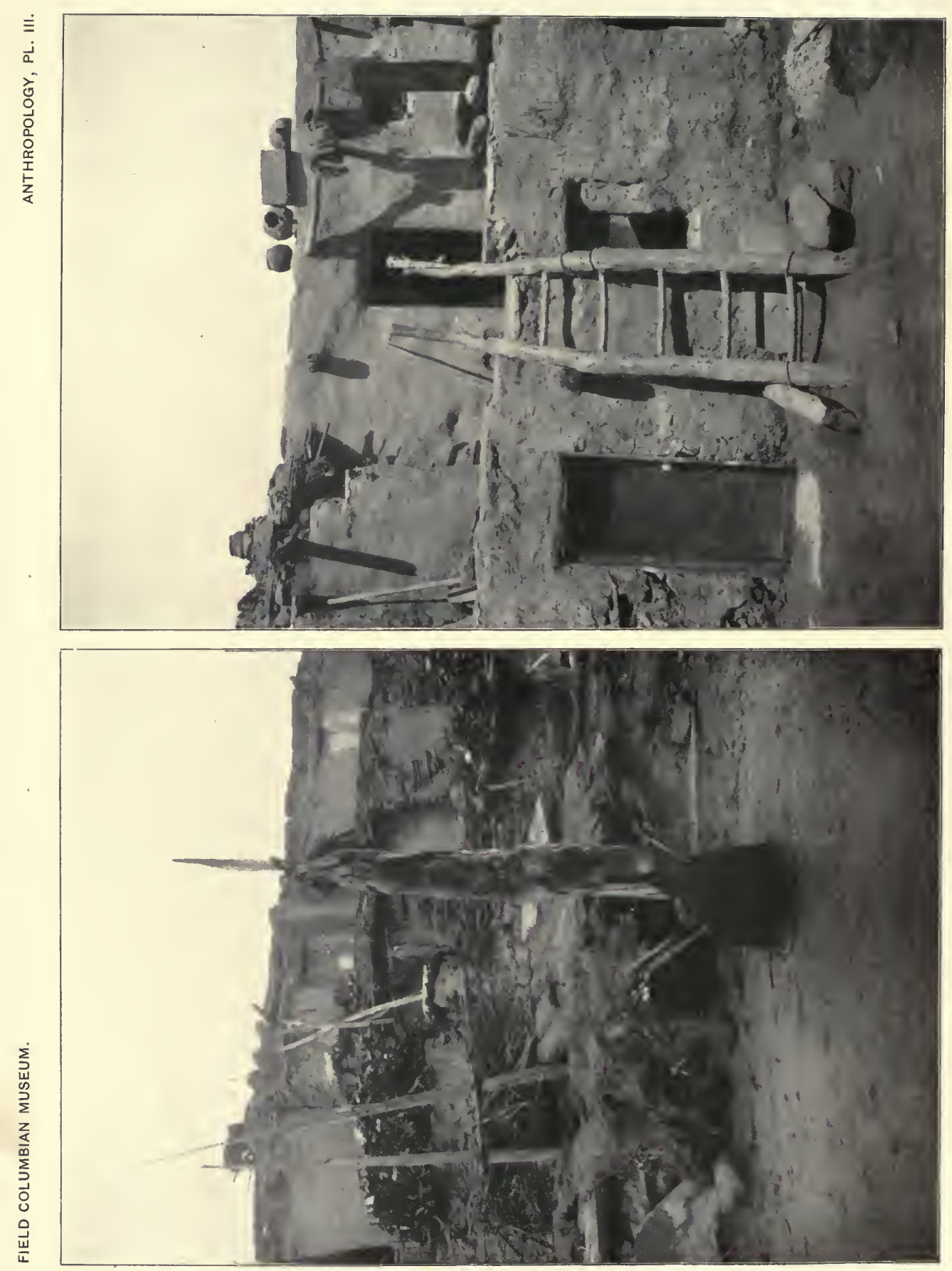
No. 1. The Hawiovi Kiva.

PL. III.

This is the kíva in which the Oáqöl ceremony takes place. Unfortunately a negative had to be used that shows the Nátsi or society emblem of the Flute Fraternity, which also holds its ceremonies in this kiva.

No. 2. The Home of the Sparrow-Hawk Clan.

From the top of this house all ceremonies in the village of Oráibi are announced by the crier, whose duty it is' to make these announcements. On the roof is situated a small shrine, not visible on the plate, however, in which the crier deposits certain prayer offerings, before he makes announcements. 


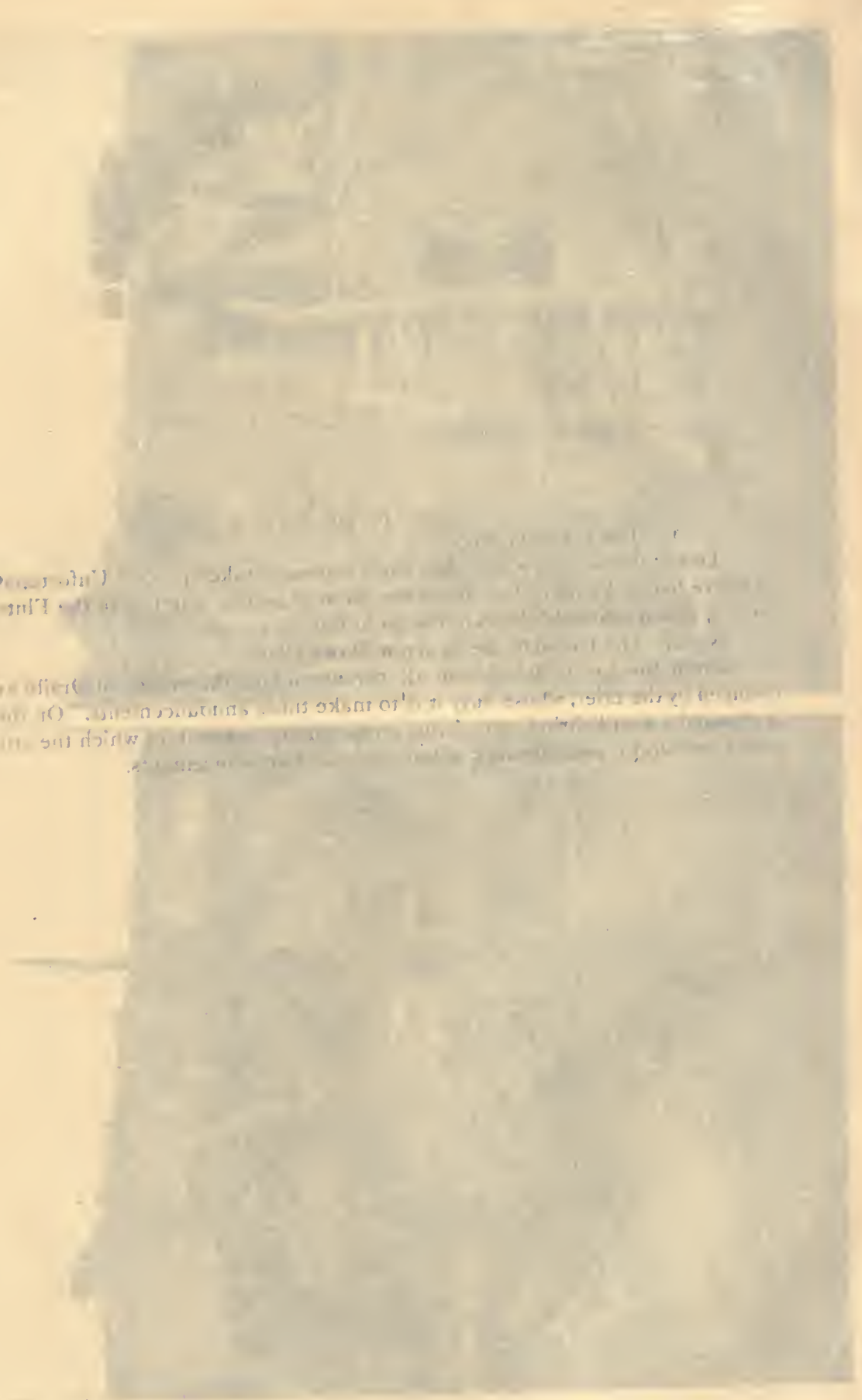

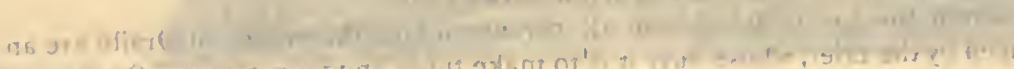

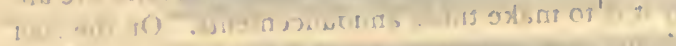

(

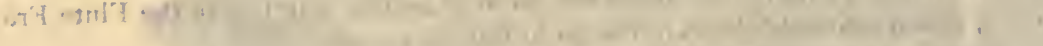


37. Qömáhonguöma

38. Tîwángyaonöma

39. Kélmösi

40. Pungñáwunka

4 r. T’ūwámönöma

42. Honápsi

43. Nasíwunka

44. Macáwunci

45. Sikáhoinöma

46. Lötókciwa
Tab (Rabbit) clan.

Tab (Rabbit) clan.

Tab (Rabbit) clan.

Táwa (Sun) clan.

Táwa (Sun) clan.

Honáni (Badger) clan.

T'cūa (Rattle-snake) clan.

'Tcūa (Rattle-snake) clan.

Katcína (Katcína) clan.

Íshawuu (Coyote) clan.

It will be seen from the above list that the number of participants, belonging to the different clans is as follows: ${ }^{1}$

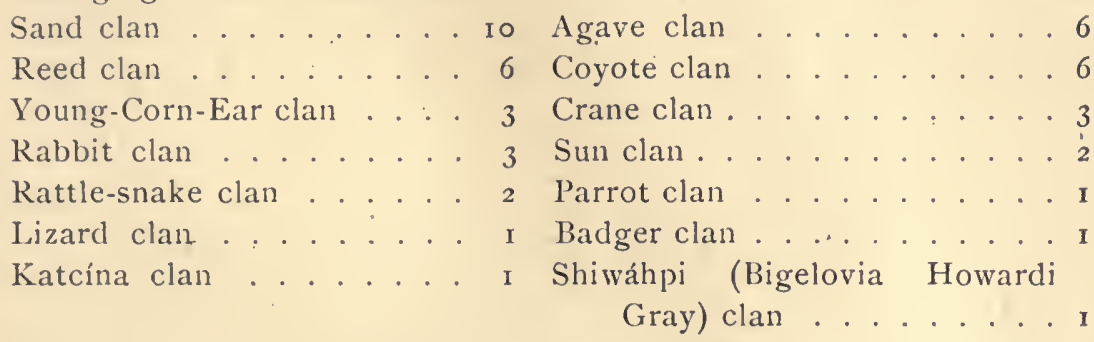

\section{THE CEREMONIAL KÍVA.}

In the village of Oráibi are thirteen kivas, or underground chambers, one of which was, up to about two years ago, considered the exclusive property of the women. At that time it was rebuilt, and ever since then it seems to be used the same as the others by a certain group of men, who turn the kiva over to the women when the latter wish to use it for a ceremony. In this kiva the Maraú Society hold their ceremonies; in fact, the kíva is usually called Maraú kíva. The other two women's Fraternities; the Lálakontu and Oáqöltu hold their ceremony in the Hawíovi kíva. (See No. r, Pl. III.) It is claimed by some that this name is derived from "hawiota," "gone down," and "ovi," a suffix denoting an "elevation," "height," or sometimes mean-" ing "up," "on top," because there is an elevation close to the kíva from which they have to descend in order to get to the kiva from the adjoining streets. In the course of time this knoll has somewhat disappeared, but the ground all along the north side of the kiva is still

'Every Hópi clan is related to one or more other clans; for instance, the Sand, Lizard and Rattle-snake; the Coyote, Yellow-Fox, Gray-Fox, etc.; the Young-Corn-Ear, Cloud and Shiwahpi, Parrot, Katcina and Tobacco; the Badger and Butterfly clans, are respectively related to each other; and any one belonging to one clan in any of these groups really belongs to all, but specially to that one in the group; in other words, he belongs to one, but is related to the others. In fact, the Hópi words for relative, related, etc., refer to clan relationship only. 
considerably higher than on the other sides. ${ }^{1}$ It is also claimed that later on, when repairing this kíva, it was also called Aoát (Bow) kíva, because the people belonging to the Bow clan, who built it and were its principal occupants, still controlled it. At present the men who occupy that kiva belong to many different clans, as is the case with every Hópi kíva, although the clan who has built it is usually considered to be the owner of it.

Besides the Oáqöltu, the Lálakontu and the Masílālentū (Drab Flute) Societies celebrate their ceremonies in the Howiovi kiva. The kiva is of the usual size, about twenty-four feet long, twelve feet wide, and from seven to ten feet high, being lower at the two ends. The portion north of the ladder is about a foot deeper than the part south of it; a banquette, about twelve inches high by about fifteen inches wide, runs along the two sides and the north end of the deeper portion. In fact, the kiva is constructed in essentially the same way as all the other kívas in Oráibi.

\section{TIME AND DURATION OF THE CELEBRATION.}

The Oáqöl ceremony is observed every year of uneven numbers, alternating with the Iagọn and Maraú ceremonies, which take place in the years of even numbers. It always occurs in the latter part of October or the first part of November, or both, as the following dates show:

I 893, October 26 to November 3 .

I 895 , November I to November 9.

I 897 , October 23 to October $3 \mathrm{I}$.

I899, October 28 to November 5 .

I 901 , October 22 to October 30.

I903, November 3 to November II.

Eight days before the beginning of the ceremony, a short preliminary ceremony, the so called Báholawu (báho-making), takes place in the morning. in the ancestral home of the Sand clan, and another gathering of a few of the leaders in the house of the kíkmongwi in the evening; whereupon the public announcement of the ceremony follows early the next morning.

${ }^{1}$ Others claim-and this is probably correct-that the name is derived from certain decorations on the inside of certain Hopi bows, that run down (hawfota) on each edge of the bow. An analogy may be found in the name of another kiva (Hochíchwi), which was also originally built by the Bow clan and named after a zigzag line (hochíchvāita) on certain Hópi bows. It hen later it was repaired by the Badger clan, it was called Honáni (Badger) kíva. 
THE LIBRARY

OF THE

UNIVERSITY OF ILLINOIS 

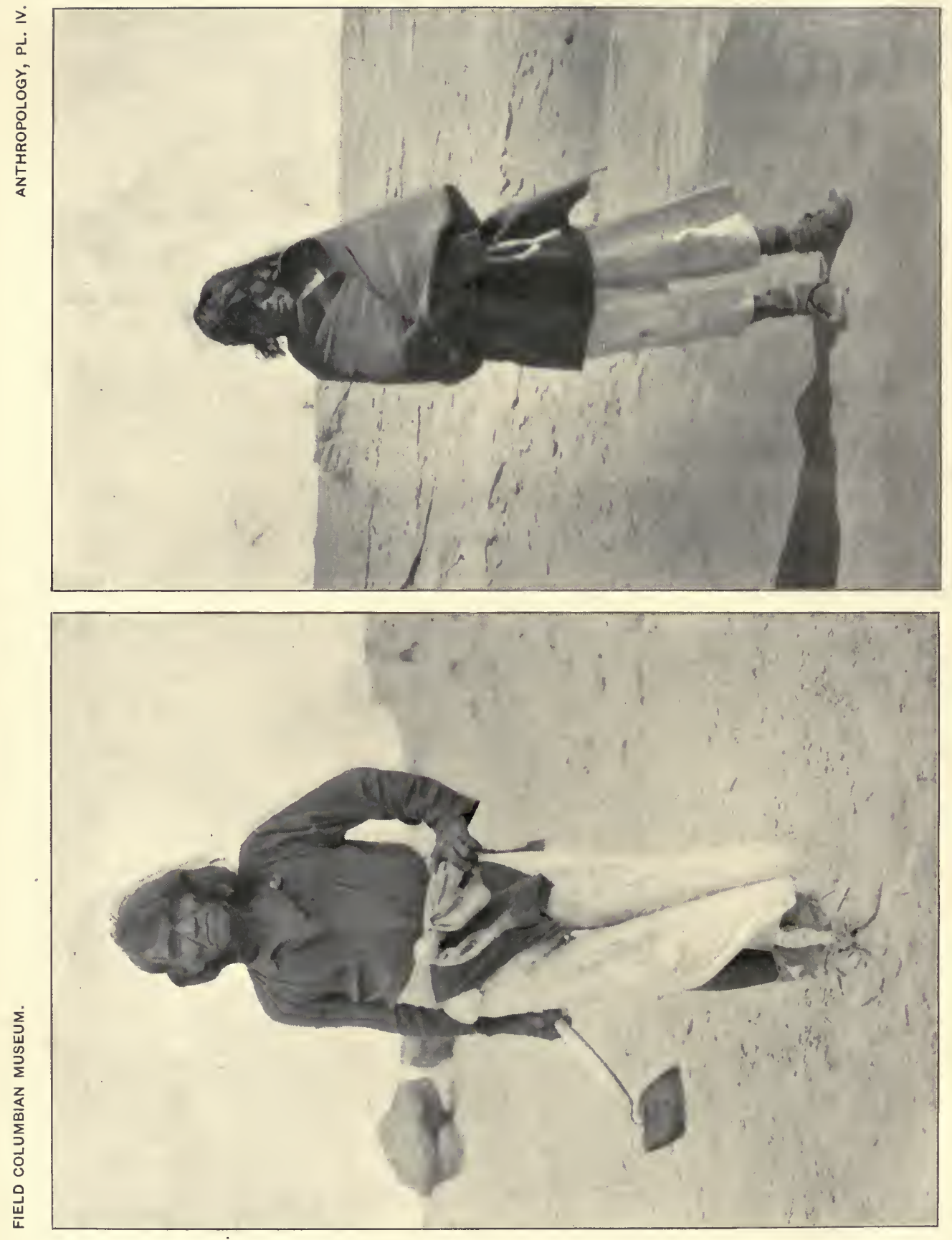
PL. IV. TWo Prominent Oráibis.

No. 1. Lóloloma, the Kíkmongwi or Village Chief.

Lóloloma has for many years been a very prominent figure in the village of Oráibi, not only on account of his position, but on account of his friendly attitude towards the government and its efforts to civilize and educate the Indians, which led to a serious rupture between the inhabitants of Oráibi. Lóloloma remained at the head of the liberal faction, while the conservative faction elected its own chief, and contentions have existed between these two factions now for about twelve years. This rupture has also done very much towards modifying, undermining, and even partly destroying some of the Oráibi ceremonies. Lóloloma was at one time, years ago, imprisoned by the hostile faction in one of the kivas, and he believes to this day that he would have been left in that kiva to starve if the representatives of the government had not rescued him. The plate shows the chief as he returns from his field in the valley.

No. 2. Lománkwa, the crier who has for a number of years announced publicly the ceremonies controlled by the liberal faction of Oráibi, those of the conservative faction being announced by their own crier. This man perished about a month ago in a ditch which he was digging, trying to find some moles that were destroying his peach-trees. The ditch caved in on the man and his body was not found until the next morning. 



\section{PRELIMINARY CEREMONY.}

\section{a. BÁHOLAWU. (MAKE BÁHOS.)}

Eight days before the beginning of the Oáqöl ceremony, a few of the leaders, usually Másátoiniwa, Hómikini, and Qöyángösi, ${ }^{1}$ assemble early in the morning in the ancestral home of the Sand clan for the so-called báholawu (báho-making). On this occasion usually the following prayer-offerings are made:

By Masátoiniwa, one báho, one púhu, and eight nakwákwosis.

By Ngơsi, eight nakwákwosis.

By Hómikini, eight nakwákwosis.

In case other women are present, they also make four nakwákwosis each.

These are disposed of as follows, after all have sinoked on them: The báho made by Masátoiniwa, as well as four of his, four of Hómikini's, and four of Ngósi's nakwákwosis are taken to the kíkmongwi's house for further disposition in the evening. All other nakwákwosis, one from each participant, are deposited north, west, south, and east of the village, by different members of the Society, who are called in for that purpose if they have not participated in the báho-making.

\section{b. TÍHTINGAPYANGWU. (CONSECRATING.)}

In the evening Ngósi proceeds to the house of the kíkmongwi (village chief ), where she is met by the kíkmongwi Lóloloma (No. I, Pl.IV), his brother Shókhungioma, and their sister Pungñanơmsi, ${ }^{2}$ and the cháakmongwi (crier chief Lománkwa). (See No. 2, Pl.IV.) The tray with the prayer offerings brought by Ngofsi from the house of the Sand clan, as already stated, is placed on the floor, and those present assemble around it, squatting on the floor. All smoke over the tray, and then each one picks up the tray and utters a prayer over it, whereupon usually a few words are said about the approaching ceremony. From this and from the prayers or talks uttered over the prayer-offerings this iittle ceremony is sometimes also called móngwlalawaiyi (chief's

${ }^{1}$ This priestess is usually called by her abbreviated name, Ngốsi, and will be so called through. out the paper.

2 While Lóloloma is really the village chief, his brother and sister are also often called kíkmongwi. This office and its privileges seem to be vested rather in the lamily than in one particular member of it. The ancestral home of this family is now occupied by Pungñanomsi, and here this meeting takes place. 
talk). After the ceremony is over, Pungñánömsi serves a supper, whereupon all go to their respective homes, the crier taking with him the tray with the prayer-offerings.

\section{c. CHÂALAWU. (CRY OUT.)}

At about sunrise the next morning the crier proceeds with the prayer-offerings to the ancestral home of the Kél-Nyamu (SparrowHawk clan, No. 2, Pl. III), from which all religious ceremonials that are publicly announced, are cried out. On the roof of this house is situated a small shrine. 'Into this the crier deposits the prayer-offerings and some sacred meal, and then announces the approaching ceremony in the following words:

“Úma kwiníwii kíiyùngkamu kúkūiwa húwamu! Úma táwānge kíiyungkamu kúkūiwa hứwamu! Úma tátöö kíiyungkamu kákūiwa háwamu! Úma hópoo kíiyung-kamu kákūiwa háwamu! Nu úmui áaonani; hápi kush yáhpinen shúhkop tálat épak íma Óoaqöltu kiwánāw unángway tawíyanikāy pasíonaya. Pásaat tálat ak ítam ka nánamihin unángwaykahkang shópkawat sínum yéshwani. Nap hákakwat móngwi yóilöki akw ítam ókwatówani. ". Put akw pas pai ítam móngwactūtini. Móngwactūtinikae tūnátyaokahk̄ang yáhpi shópkawat sínonı yéshwani. Yán hakam itámui shópkáwatui sínmui itánamu itángumu angqitámui öokálantota. Yán hákam tủnatyaokah kang shópkawat sínom yéshawni. Pai háhlaikahkango, önkáokahkango."

\section{Translation.}

You, living in the north, loom up, please! ${ }^{\text {Y }}$ You, living in the west, loom up, please! You, living in the south, loom up, please! I shall inform you [thus]: Now then, after this, in sixteen days, then these Oáqöltus, because they shall have good hearts, shall perform. Until that many days we, all the people, without having any contentions with (among) each other, shall (must) live. ${ }^{2}$ (Perchance) some chief shall pity us with dropping rain. With that we must accomplish ${ }^{3}$ (conclude) [this]. Because it has been accom-

1 The word translated "please" is an exclamation of welcome, and often added to a request, as we add the word "please" - as " páo húwamu!" "come here, please!"; "húwamu nónowaal" "eat, pleasel" But while in such instances the word "húwamu" corresponds to the word "please," it can. not be used in every place where the word "please" is used in the English language.

2 Any worry, sorrow, or anger disqualifies a Hopi, as a rule, to participate in a ceremony, and contentions and quarrels in the vilıage are supposed to interfere with the efficacy of a ceremony.

"The word "móngwactūti" (accomplish, conclude, be done, etc.) occurs in these somewhat obscure phrases in many religious Hópi talks, announcements, etc. I am told that what is referred to is the almost constant anxiety and concern about rain, and the meaning here is that when the rain comes that anxiety and the desire for rain is concluded for the time being; at the same time the inhabjtants are admonished, especially those that have been unconcerned about the matter, to continue their earnest concern about this matter-the question of rain. 


\section{THE LIBRARY \\ OF THE \\ UNIVERSITY OF ILLINOIS}




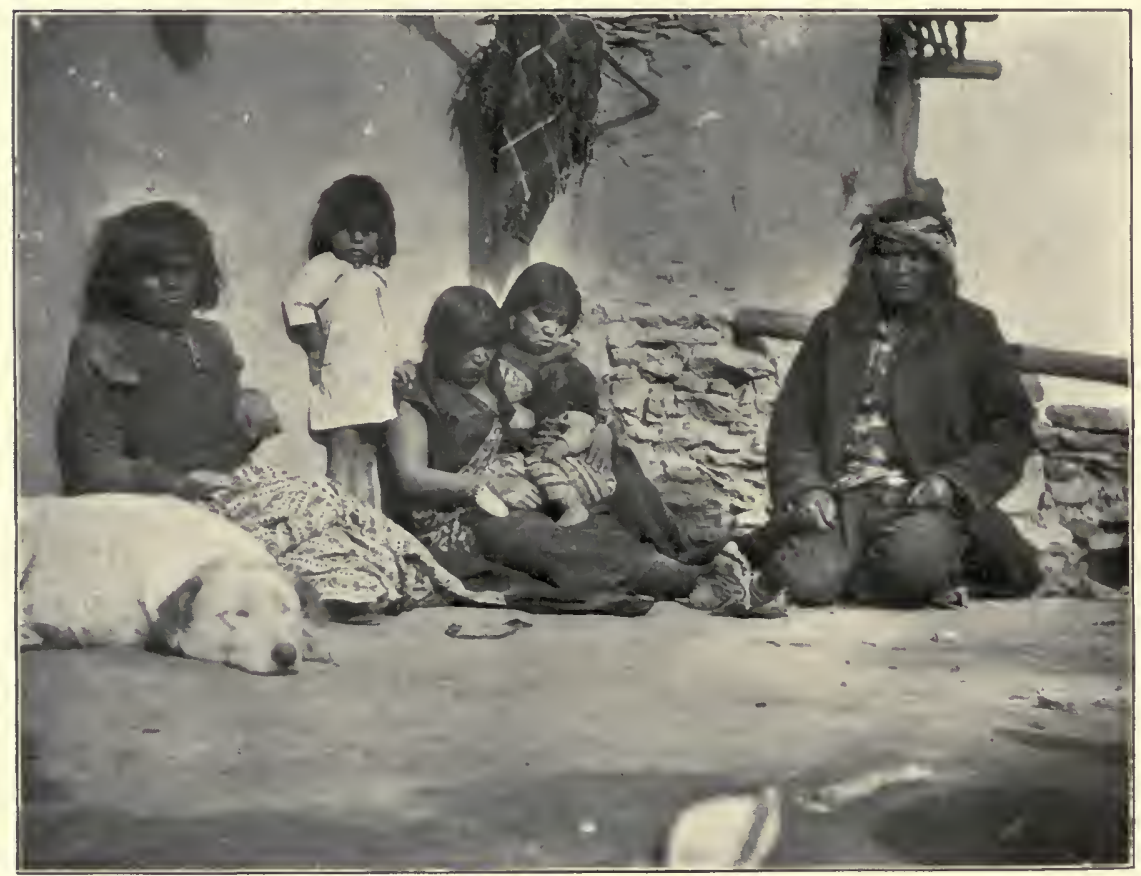


PL. V. HÓMIKINI AND FAMILY.

The plate shows the assistant chief priest, who plays such a conspicuous part in the ceremony, and is mentioned so often throughout the paper, in front of his home, and with his children and grandchildren. The young man to the left is his son, who is a cripple, his legs being paralyzed. The woman nursing the child is his daughter, the mother of the three smaller children on the plate. His sonin-law, the husband of the woman, is not present. Hómikini, besides being the assistant chief priest in this ceremony, is also, probably, the best Indian physician in Oráibi. He is a splendid botanist, and has a good knowledge of the medicinal properties of the various herbs, viewing the matter from the Hópi standpoint. 


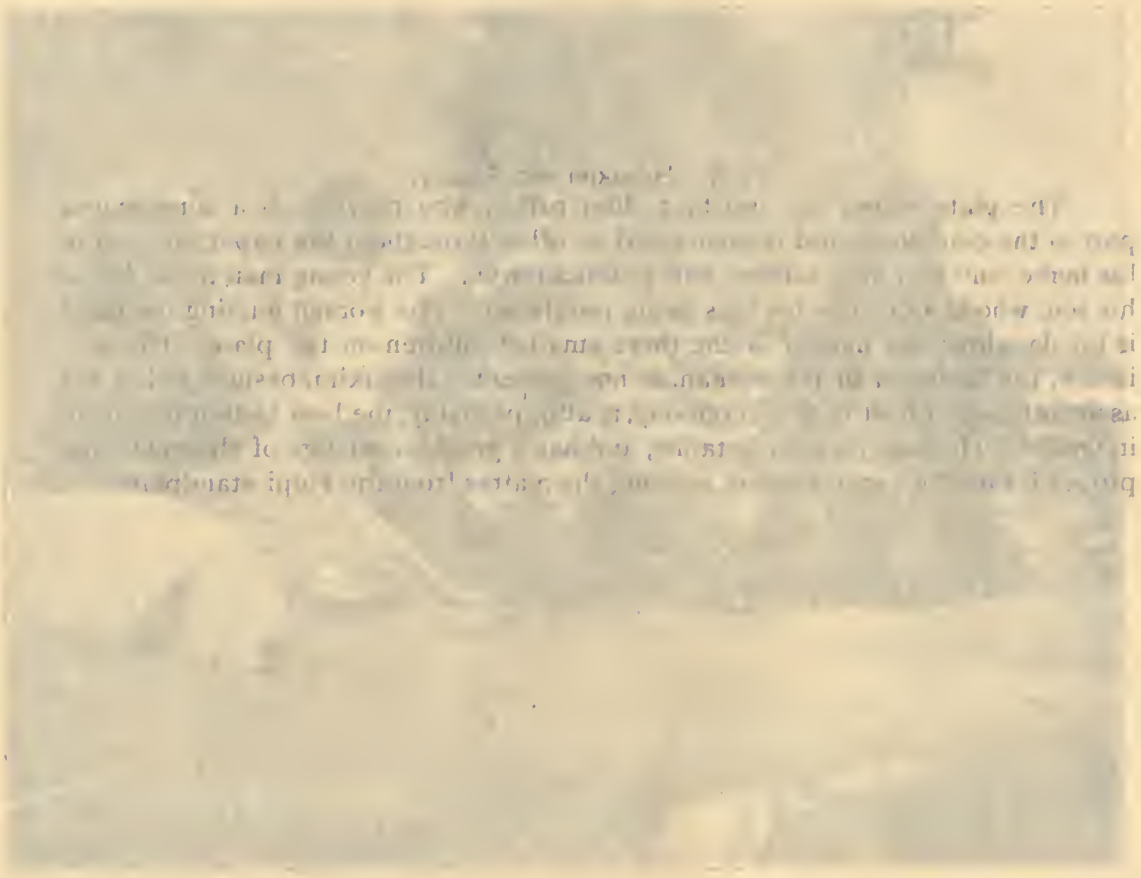


plished, ${ }^{1}$ all the people shall after that live, concerning or continue to concern themselves about it. Thus (may) our fathers, our mothers come and strengthen (encourage) us, all the people! Thus being concerned all the people shall live. (Yes) being happy, being strong (encouraged).

\section{THE NINE-DAY CEREMONY.}

\section{FIRST DAY.}

\section{SHÚSH KA HÍMUU. (ONCE NOT ANYTHING.)}

While in most of the Hópi nine-day ceremonies very little of importance takes place on the first day-as the name indicates-the opening day of the Oáqöl ceremony is of unusual importance, inasmuch as the very elaborate altar is being erected on this day.

At about sunrise the chief priest, Masátoiniwa, and the chief priestess, Ngósi, proceed to the Hawíovi kíva, the latter usually being accompanied by her little daughter. Hómikini (Pl. V), Masátoiniwa's assistant, usually also puts in an appearance early this day.

One of the first acts of Ngð́si is to sprinkle a ring of sacred cornmeal around the kiva and to put up the nátsi, or emblem of the order, at the south end of the hatchway. This emblem consists of -a flat slab about four and a half inches long, two inches wide, and about threeeighths of an inch thick, made of a cottonwood root and having a short handle at one end. The slab is painted green and has on one side in black outlines the drawing of a corn-ear. In fact, it is itself called kaô-baho (corn-ear baho) or kaó-nátsi (corn-ear nátsi).

After having sprinkled the meal ring and put up the natsi, Ngøsi sweeps the kíva. Masátoiniwa is in the mean while sitting near the fireplace and smokes. Having swept the kíva, Ngð́si, or sometimes Masátoiniwa, makes a few nakwákwosis, which the former takes with a pinch of meal and goes for some sand, which she gets from a sand hill half-way down the mesa. Having placed the prayer-offerings on the sand hill, she holds the corn-meal to her lips and says: "It nu úngem yúku; it um himúitani, níkang nu it uh táwa kímani" ("This I have made for you; you will have (own) this, but I shall take your sand along'). A part of this sand is moist, for the altar ridge, a part dry, to be sprinkled on the floor in front of the altar. She then immediately begins to construct the altar, being assisted by two or three other

${ }^{1}$ The leaders (chiefs), male and female, are here referred to, especially the village chief, crier, warrior chief, and the leader of the Blue-bird and Tobacco clans. 
women who in the mean while have come in. The altar paraphernalia is brought into the kiva, either the previous evening or early in the morning of this day, in order to prevent the articles from being seen by any one not initiated. The slabs are tied up in bundles, the small objects, such as birds, cloud symbols, etc., are kept in jars.

In constructing the altar, first a ridge of moist sand is placed on the floor in the north end of the kiva, about thirty inches long, eight inches wide, and five inches high. Into this ridge are thrust eight pairs of sticks of a strong reed, the two and two sticks being close together. The upper end of these sticks or poles lean against a heavier pole which is suspended transversely from the ceiling or roof of the kiva. To these eight sticks are fastened transversely, with yucca leaves, five pairs of the same kind of sticks, though somewhat thinner. To this framework are fastened about eighty-three slabs and sticks of different sizes and forms, which is by far the largest number of pieces on any Hópi altar known to the author. (See Pls. I and VI.) While it is highly probable that formerly these slabs and sticks were always arranged in the same order, such is not the case now. The wide slab in the middle and the sun slab always stand at the same place and a few of the others nearly so. But the arrangement of the others varies very materially in the different ceremonies. A good deal of advising and arguing generally takes place among the women on this point, which usually ends in such expressions as: "Put it on anywhere!" "It is inmaterial where you tie it!" "That way it is all right," etc. The work of erecting the altar is superintended by Ngósi, though I have now and then heard Masátoiniwa give advice or express an opinion. In i 893 , however, he repainted a number of the slabs; he and Hómikini also assist in getting the objects for the altar in proper shape, make the nakwákwosis that are fastened to the wooden birds, cloud symbols, etc. They also card and spin cotton for making prayer-offerings. Masátoiniwa usually prepares the so-called "mohóngöla," 'The latter consists of four lengths of yucca (móho) leaves, which are tied together by the ends at four different places, thus forming a ring or wheel (ngóla). To each of the four knots is tied a nakwákwosi. This wheel is used in initiating new candidates, as will be described by and by.

Among the objects usually prepared by Hómikini at this time are the louse scratchers (náhringpi, lit: self-scratcher). These consist of a stick eight to ten inches in length and about a quarter of an inch thick, bent into a triangle with one end projecting. (See D, Pl. VII.; This stick is wound closely with cotton twine, a few tiny blue-bird feathers being fastened to each of the three corners. One of these 


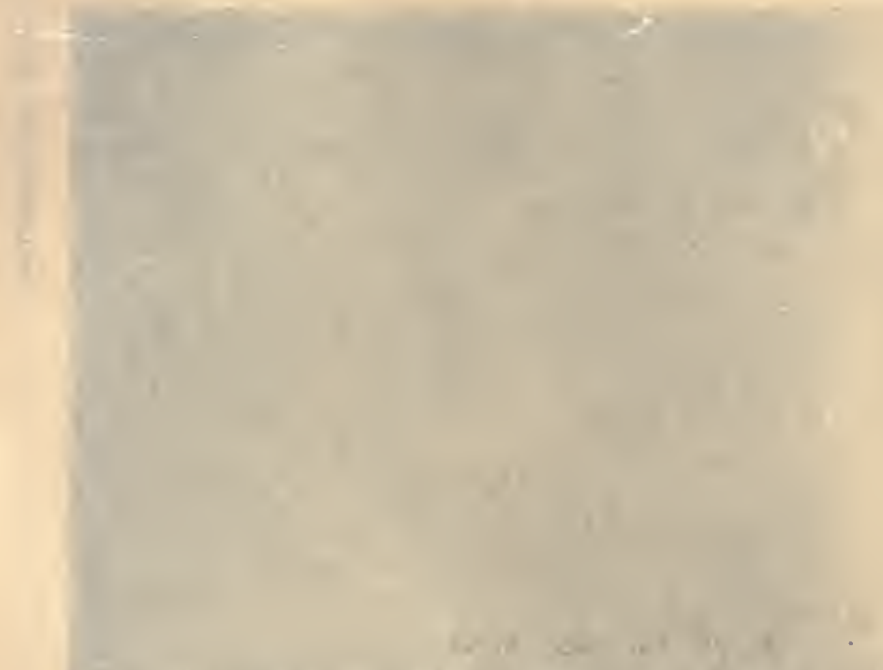

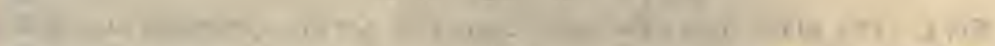

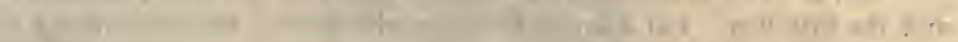
.

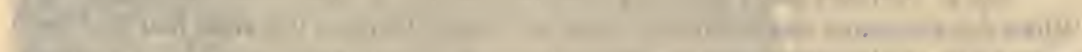

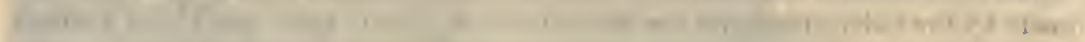

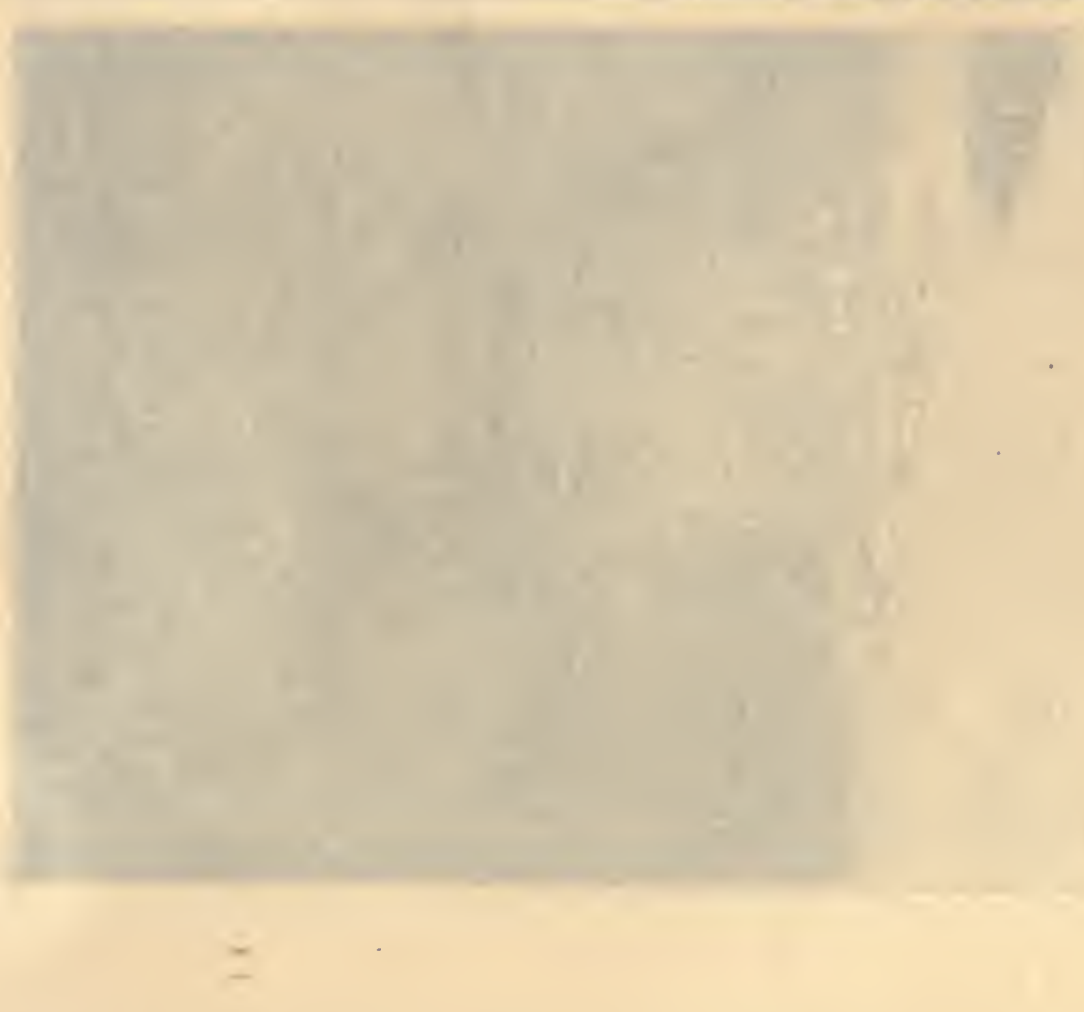


PL. VI. THE OÁQÖl ALTAR.

No. I. The plate shows the altar completed for the ceremony on the first and the fifth day. For a full description of the altar, see frontispiece.

No. 2. On this plate the altar is shown partly completed on the eighth day. When the exposure was made the cloud picture in front of the altar had just been made by the chief priest, but the medicine bowl, ears of corn, and cloud symbols, etc., had not yet been placed in position. 

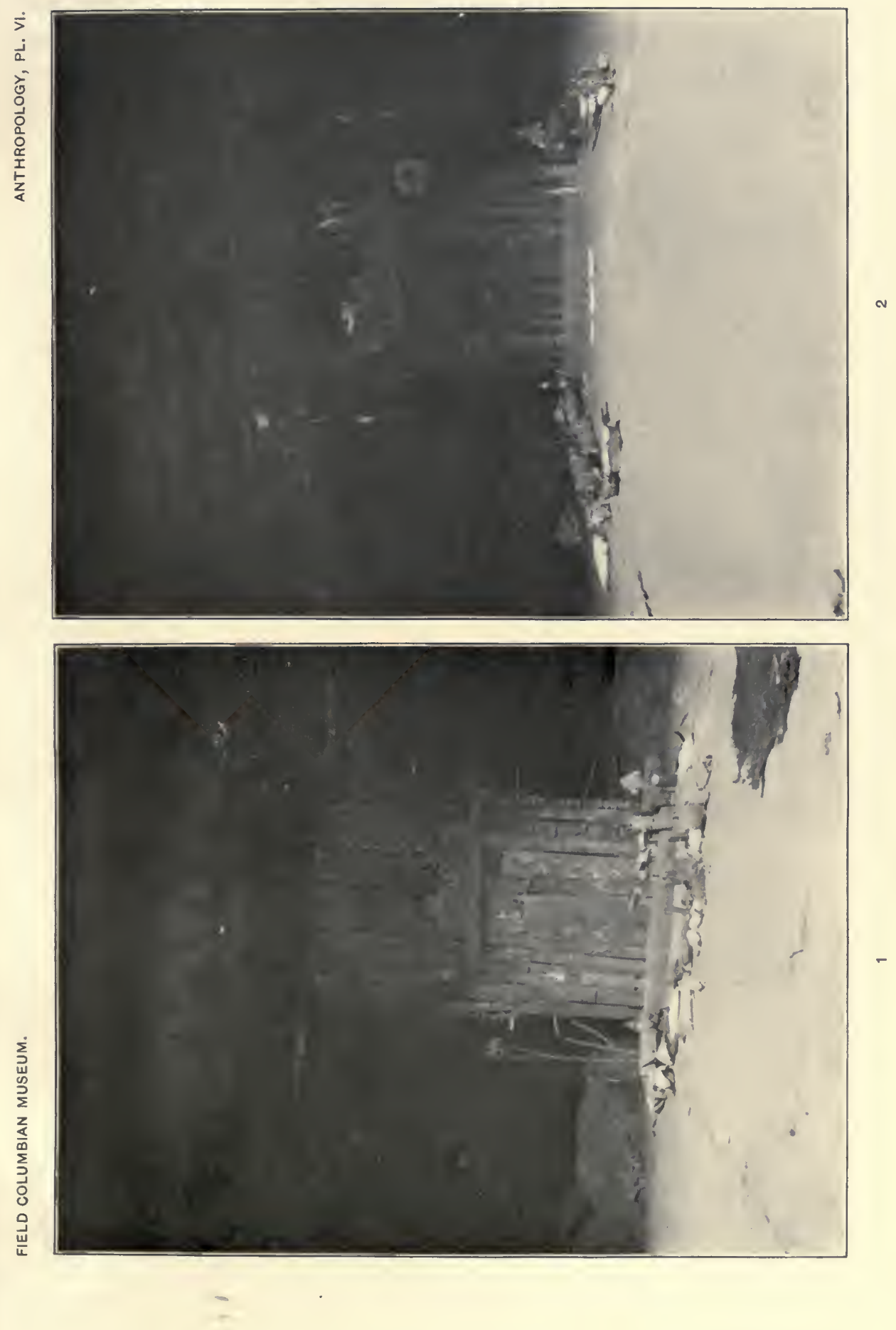


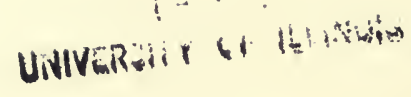

1

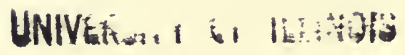


objects is given to eách girl that is entered as a candidate for initiation, to be used by her during the first four days, instead of the finger nails, in case it should become necessary to scratch the head.

As soon as the upright part of the altar is completed, Masátoiniwa sprinkles dry sand in front of the sand ridge, sifting it through an old tray. Upon this sand he traces, with the powder of a black shale, the outlines of a cloud symbol.' This 'consists of three semicircles, from the base of which run about twelve lines, to and up the sand ridge. These lines symbolize falling rain. The semicircles are filled with a thin layer of sacred meal, and on the apex of each is drawn the figure of a turkey feather nakwákwosi. ${ }^{1}$ (See No. 2, Pl. VI.)

When Masátoiniwa has completed the cloud symbol, Ngósi places before the altar the birds, figurines, crooks, medicine bowl, mortar, etc., in which she is sometimes assisted by Hómikini, or one of the older women. The men fasten to a joist on the east side of the altar a sóhu (star) consisting of two sticks about six inches long and about three-quarters of an inch thick, tied together crosswise. To each of the four ends of these sticks is tied an eagle nakwákwosi. (See Pl. VII.)

While these preparations are going on the two men, but especially the chief priest, frequently indulge in smoking at the fireplace, without which the ceremony, and in fact any ceremony, would not be considered efficacious. Occasionally girls or children are brought into the kiva that are not yet members. These have to go at once through the first steps of initiation. Ngósi sprinkles a corn-meal circle on the floor in the south-east corner of the deeper portion of the kiva, on which is placed the mohó-ngöla, already described. Into the center of the circle she places a small pinch of corn-meal. The candidate steps into this circle, or if it be a small child, is placed and held there. ${ }^{2}$ Two women take hold of the mohó-ngöla, one on the east, one on the west side, and raising it up and down four times, say: "Íta ung wúngwni" ("We cause you to grow up"), whereupon the candidate, who holds in one hand a white corn-ear, in the other a pinch of sacred meal, steps or is led to the altar and sprinkles the meal towards it. Those who are old enough, say over five years old, are seated on the floor in the east side of the kiva, the smaller ones remain in the care

${ }^{1}$ This appendage, which is found on many drawings of cloud symbols, represents the feathers on objects, representing clouds (such as tablets on masks, idols, etc.). It also represents the feathers worn in the hair by participants in a ceremony, by Katcinas, and that are tred to the hair lock of the dead, etc. These feathers are called "nákwa" (prayer, wish), sometimes "ómaw" (cloud) nákwa.

"Every candidate for initiation is brought into (pána) the kiva by some woman (or in men's fraternities, by some man) who may be any one selected by the parents, but must not be a clan relative of the candidate. This godmother (or godfather) is then also forever called be mother (or father) of the one they have Oáqöl-vana, Tcú-vana, Lắn-vana, etc., (lit.: Oáqöl-put in, etc.), as the case may be.

Snake-put in, Flute-put 
of their mothers. Those who act as sponsors or godmothers for the novices now tie a nakwákwosi into the hair of their respective "wards," and those of the latter who sit on the floor are handed by Hómikini the louse scratcher, to each of which are tied four nakwákwosis, which are to be deposited by them south of the village, one on each of the four succeeding mornings. I have never seen a boy initiated, except among the sinall babies, and am told that it very seldom occurs.

Soon after dinner Masátoiniwa inakes one púhu (road) (see F, Pl. VII) and four nakwákwosis to be deposited at a spring by Ngósi. At about three o'clock active preparations are made for the evening ceremony. The kiva is swept, some finishing touches are made on the altar, and Ngósi gets ready to get the water to be usęd in the ceremony. After Masátoiniwa has tied a nakwákwosi into her hair, she puts on her ceremonial robe (atôë), takes a móngwikuru (chief's jug) (see C, Pl. VII), a tötðqpi (whistle made of an eagle wing bone) (see B, Pl. VII), an old eagle wing feather, a corn-ear, some honey, sacred meal, and the pâhu and nakwákwosis made shortly before by Masátoiniwa, and goes to Iánva, the principal spring on the west side of the mesa. Near the spring she deposits one of the nakwákwosis and some meal on the trail, throwing also a pinch towards the spring. She then whistles four times with the bone whistle, deposits the rest of the nakwákwosis and soine meal in the spring, spurts the honey on the water, then dips water into the móngwikuru with the feather four times, and then with the corn-ear four times, whereupon she fills the vessel. Hereupon she says: "Tumái shóshoya nu úmui chámto" ("Go we! all (of) you I have come to fetch"), ascends from the spring, places the púhu on the trail, sprinkles some meal on it, throwing also a pinch towards the village, and then returns to the kiva. Here she stops on the east side of the ladder, Masátoiniwa sprinkles from her to the altar a line of corn-meal, returns and takes from her the objects, goes along the meal line to the east side of the altar, and assuming a kneeling position, hums a song over them waving them slightly up and down to the time of the singing. ${ }^{1}$ He then places the objects on the floor, takes an old buzzard feather and a pinch of ashes, and returns to the priestess, who has seated herself on the elevated floor of the kiva east of the ladder, her feet resting on the floor of the deeper portion of the kíva. (See Pl. VIII.) Standing in front of $\mathrm{Ngósi,} \mathrm{Masátoiniwa} \mathrm{sprinkles} \mathrm{some} \mathrm{of} \mathrm{the} \mathrm{ashes}$ along the feather and then hums in a low voice one of the so-called Náwohchi táwis (discharming songs) in an unknown language: 


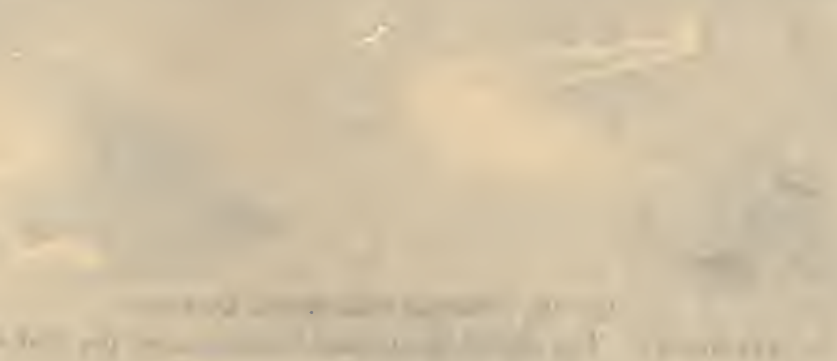

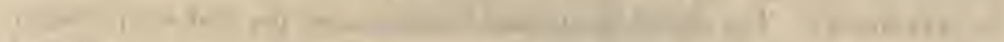

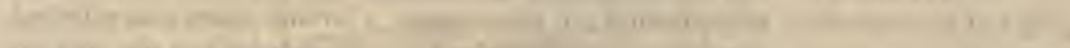

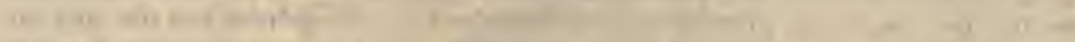

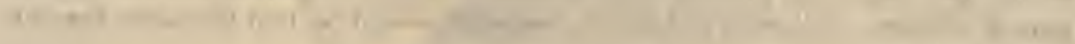

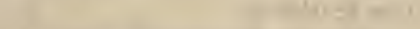

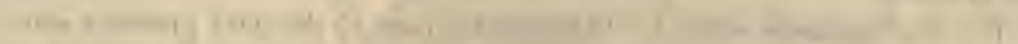
T.

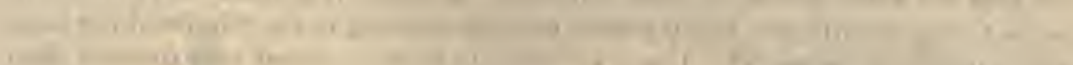
1.

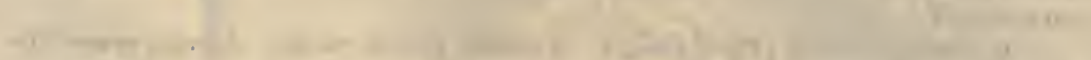

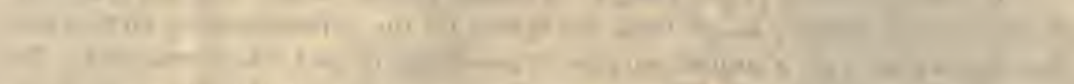

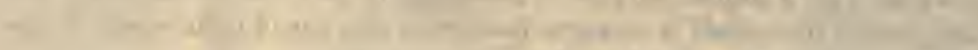

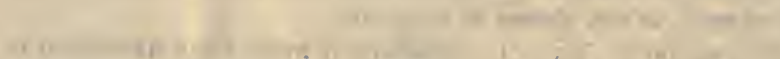

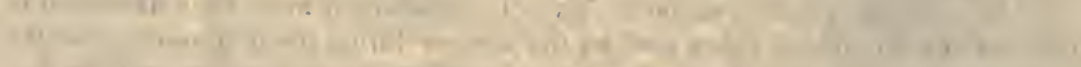

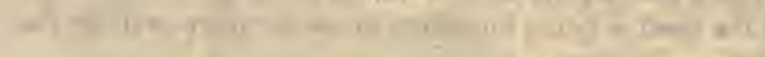

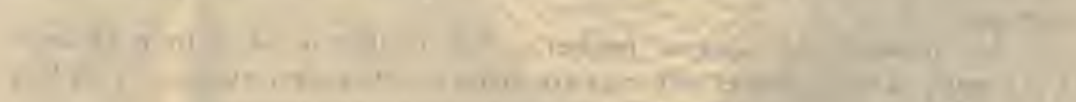

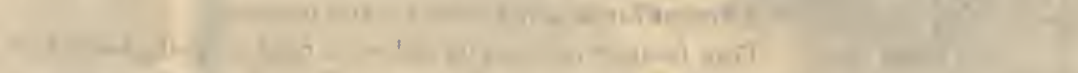

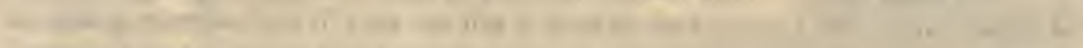

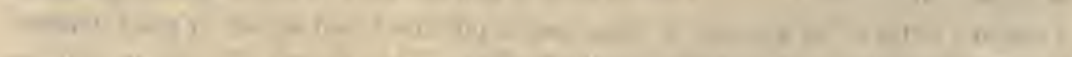
0
$M$

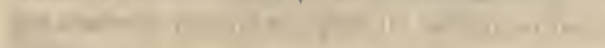


Pl. Vil. Various Ceremonial Objects.

A. Hurúnkwa. The object is supposed to represent the makwánpi (aspergill), but unfortunately in preparing the photograph, a wrong object was selected, so the picture on the plate is really a hurúnkwa, or head-dress, but the only apparent difference between this and the aspergill would be, that the latter has only a few feathers.

B. Tötö́qpi (bone whistle). This object is used by the chief priestess when she gets the water for the ceremony from the spring. It is made of a bone of the eagle's wing, a little wax being placed into the opening in the middle of the bone, which produces the sound. These whistles are used in almost all extended Hópi ceremonies.

C. Móngwikuru (chief's jug). A netted gourd vessel. In this vessel the chief priestess gets the water from the spring for the ceremonies; in fact, vessels like this are used for a similar purpose in nearly all Hópi kiva ceremonies. The object attached to the vessel is an eagle feather; a tiny ear of corn, which is also often attached to these vessels, is not shown in the plate.

D. Náhripi (self scratcher). This object, which is more fully described in the text of the paper, is being used by the novices during the first four days of the ceremony for scratching the head, it being forbidden to use the finger-nail for that uprpose.

E. Nakwákwași (prayer feather). The feather is taken from an eagle. Very many of these prayer offerings are made in connection with nearly all Hópi ceremonies, feathers of different birds being used for the purpose.

F. Púhu (road). This feather offering is called a road or path, because it is usually placed in a path, or when such is not the case, it represents or points out a road or path, from which it is often called púhtavi (road leaver or road marker). It is generally made of an eagle breath feather. This prayer offering is also prepared in almost all Hópi extended ceremonies. 


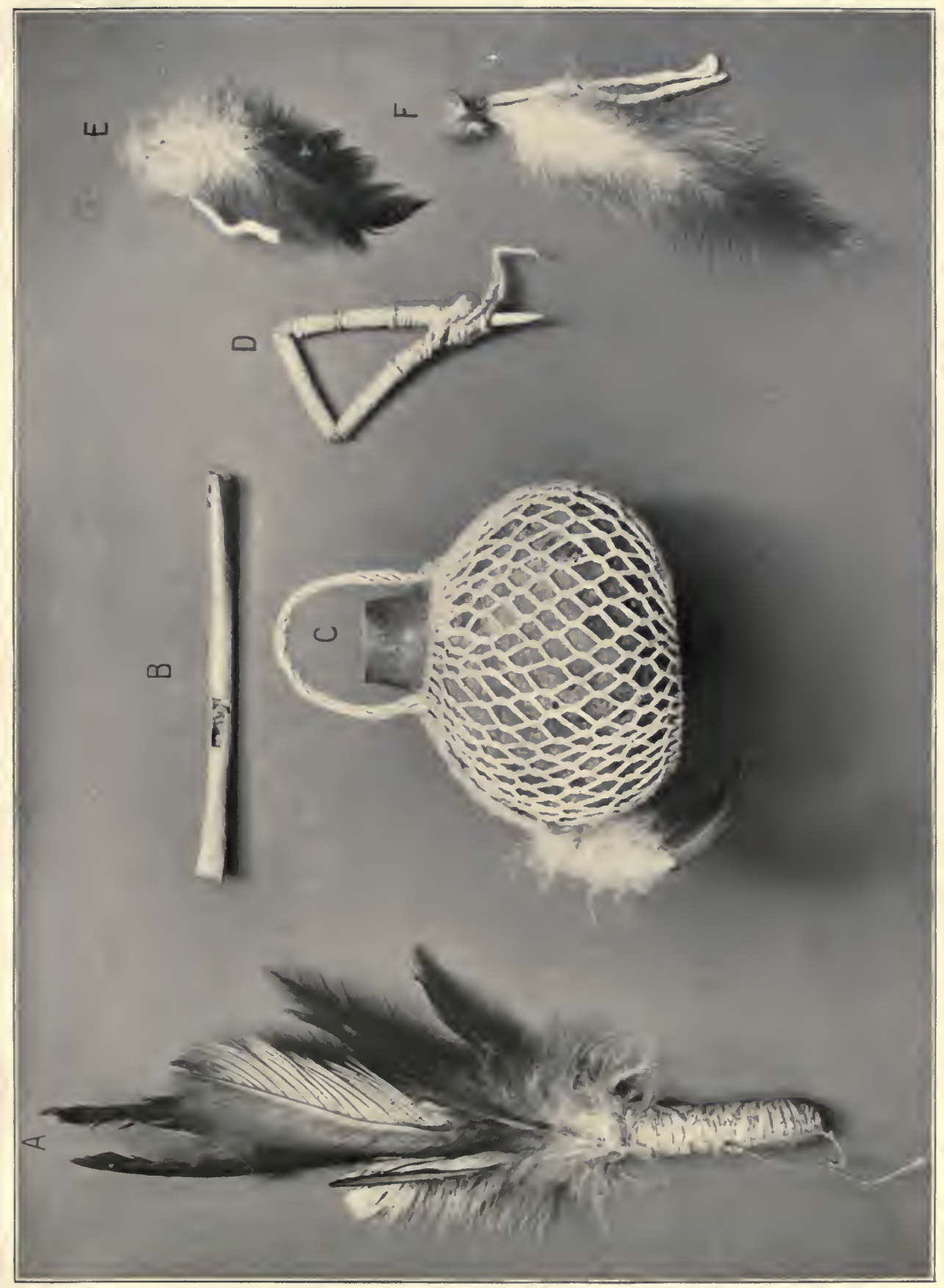


THE LIBRARY

OF THE

UNIVERSITY OF ILLINOIS 

Pl. Vili. The Chief Priestess Waiting to be Discharmed.

The plate shows Ngösi immediately after her return from the spring with the water to be used in the ceremony. While the chief priest is consecrating the water near the altar, she is silently waiting at the foot of the ladder until he is through, when he steps up to her, and standing before her, discharms her by slowly humming a song and sprinkling ashes along a feather and brushing it off the feather toward the hatchway, as described in the text. 


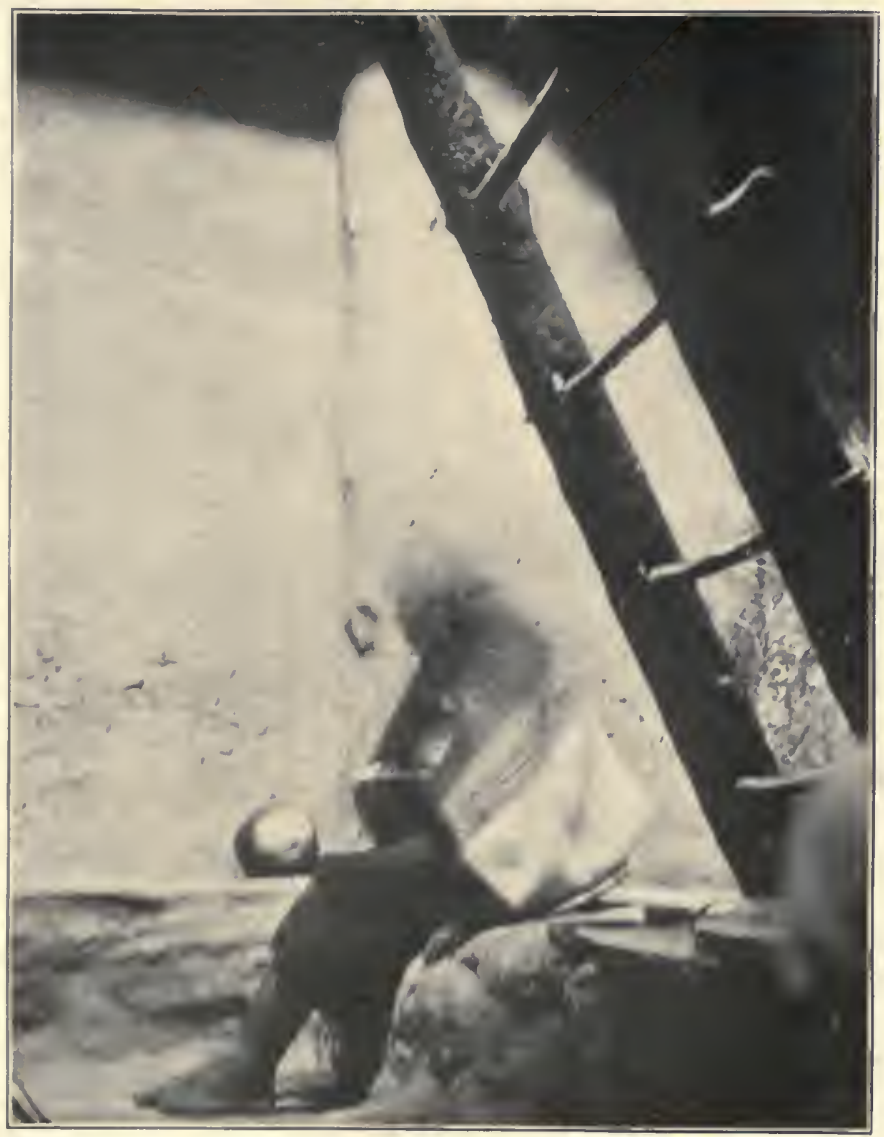




\section{THE LIBRARY \\ OF THE \\ UNIVERSITY OF ILLINOIS}


"Hahaohaaohahaoho

Shiwahawaiyaha

Shiwahawawaawaahayi

Hoolooloholohololo."

(The above is repeated.)

"Tihirahapahaimaha

Hahaowiirahainaha

Hayahayaololoci

Hayahaololo

Hayahahayoloolocihihii

Tihirahapahaimaha

Hahaowiirahainaha

Hayahayaololoci

Hayahaololo

Hayahahayol,oolocihihii

Hahaohaaohahaoho

Shiwahawaiyaha

Shiwahawawaawaahayi ;

Loolooloholohololo."

During every verse he touches the head, shoulders, back, and knees of the priestess with the feathers, then swings it from right to left over her head several times and wipes the ashes from the feather towards the hatchway, sprinkling, of course, new ashes on the feather for each new performance. This he does six times. When he is through he unties the nákwa from her hair and ties it to the móngwikuru; she lays off her robe and then goes about her business. ${ }^{1}$

More participants keep coming in as the time of the evening ceremony draws nearer; now and then a new candidate for initiation is brought in; these, however, consist principally of the babies whom the mothers cannot leave at home. The women who have been in the kiva most of the time may be seen at this time eating watermelons, peaches, piki, etc. When finally the time for the singing has arrived, all arrange themselves in front of the altar, the older women seating themselves on the floor, the novices along and on the east banquette, the girls, who are already members, on the west banquette. On one occasion I noticed that Hómikini and the wife ${ }^{2}$ of Masátoiniwa made

1 One time the priestess bad forgotten to take the vessel along, and hence brought no water Masatoiniwa, however, went through the consecrating and discharming ceremony in the usual manner, taking the móngwikuru from the altar where it had teen forgotten. Ngósi commented a good deal on the occurrence to the other women, and when the discharming ceremony was over she fetched some water in a common vessel and without any ceremony.

"Hómikini belongs to the Snake, Lizard and Sand clans, the woman to the Kwan (Agave) clan, who owns the fire. Homikini says he makes the prayer-offering because he keeps up the fire 


\section{if Field Columbian Museum--Anthropology, Vol. VI., No. I.}

a nakwakwosi for the fire, and placed it on the floor near the fireplace; but I am told that this is done in every ceremony Ngósi, who has in the mean while put the medicine bowl, corn-ears, cloud symbols, etc., into their places, pours the water from the móngwikuru into the medicine bowl, and when all have seated themselves, sprinkles a heavy meal line from the típoni to the east side of the ladder, throwing also a pinch up the ladder towards the hatchway. Masátoiniwa then sprinkles on the same line a line of talási (corn-pollen), also throwing a pinch up the ladder. Both then take a seat in the circle. Masátoiniwa and Ngớsi say: "Pai ítam háhlaikahkang pavásionagani" ("Now we shall joyfully perform this ceremony"). Whereupon the singing commences. During the

First Song nothing of importance takes place, but during the

Second Song Talásnga, who fills the position of sprinkler, sprinkles corn meal along the north corn-ear into the medicine bowl, picks up the corn-ear and its husband, and holding them in a slanting position, beats time with them on the floor during the first verse of the song. During the second verse she does the same with the same two objects from the west side of the medicine bowl, and so on with all six. During the

Third Song Ngósi picks up a tray with fine meal, steps on the banquette north of the altar, and while the first stanza of the song is chanted, rubs with her right hand four lines of meal on the wall. While the second stanza is sung she does the same on the west wall, then on the south and east walls. While the fifth verse is sung she throws four pinches of meal towards the star already described, the object evidently being to make the meal adhere to one of the large joists. During the sixth stanza she places four small piles of meal on the floor on the east side of the altar, pressing them down with the palm side of her fingers. All these meal marks are made at certain reoccurring lines in the different verses of the song; during the intervals the priestess stands and waves the tray up and down to the time of the singing. When she is through she resumes her seat. This performance is called "(to) make a house," and it occurs in many Hópi ceremonies. The four lines are called "house." They are also made in the room in which a child is born, in which case one of them on each wall-beginning from below-is scraped off on the fifth, one on the tenth, one on the fifteenth, and the last four on the twentieth day. This scraping off of the lines I have never observed in ceremonies.

during the ceremony. On this, the fourth and the eighth day the prayer-offerings are thrust into the fire with the little corn-meal with these words: "It nuú ngem yukú, um shúyan tálat úvivitani!" ("This 1 have made for you; very brightly you will burnl") 
Fourth Song. The sprinkler first takes a little sacred meal from a tray between her thumb and forefinger, sprinkles it along the north corn-ear into the medicine bowl, then some corn-pollen, whereupon she picks up the corn-ear, holds it over the medicine bowl, and pours a little water from the móngwikuru over the corn-ear into the medicine bowl. This performance she repeats with the other five cornears during the following five verses of the song. While the

Fifth Song is chanted the sprinkler only asperges 'occasionally towards the altar, but during the

Sixth Song Masátoiniwa goes to the fireplace, lights the omáwtapi (cloud producer), a large, cone-shaped pipe which he has previously. filled, takes a little honey into his mouth, kneels before the medicine bowl, and taking the wide end of the pipe between his lips, blows large clouds of smoke towards the altar, over the objects in front of it, and into the medicine bowl. The smoke usually. causes intense coughing of the women, so that they can only keep up the singing with great difficulty. After cleaning the pipe he replaces it near the fireplace and then resumes his seat in the circle of singers.

Seventh Song. The sprinkler takes the cloud block with the butterfly on it that stands on the north side of the medicine bowl, tilts it forward so that the butterfly touches the water in the medicine bowl, and then waves it up and down slightly to the time of the singing. In this manner she "waters" the butterflies that stand on the other three sides of the medicine bowl, and then also the two birds on the west side of the altar.

Eighth Song. During the first stanza the sprinkler waves the bone whistle towards the medicine bowl from the north side, and then whistles into the bowl several-generally three-times. During the second stanza she does the same from the west side, and so on, from the six ceremonial directions, asperging with the makwánpi (aspergill) (see A, Pl. VII), after the whistling. ${ }^{\text {' }}$

During the following four songs nothing of importance takes place, but during the

Thirteenth Song Ngósi takes a tray containing a powder that consists of corn-meal and pulverized sunflower blossom leaves, stands on the north-west corner of the altar awhile, waving the tray up and down to the time of the singing, and then she rubs a little of the powder into the face of every participant, whereupon she resumes her position on the north-west corner of the altar, again waving the tray to the time of the singing. When the singing stops she places the

In Igor this whistling took place during the seventh, the watering of the birds during the eighth song. 
tray on the floor, and says, "Áskwali" (thanks)! Masátoiniwa says the same, and all three sprinkle corn-meal towards the altar. Those who do not have any in their hand are given some by the others from one of the trays. Masátoiniwa and all the women in the circle around the altar, who may be considered the leaders, hereupon say, "Pai íta öokáoyani" ("We shall be strong, or encouraged"). Ngósi goes slowly along the meal and corn-pollen line from the típoni towards, and a few rungs up, the ladder, which ends the ceremony. It is now generally about five o'clock in the afternoon. The meeting breaks up and most of the participants leave the kiva, the girls generally leaving first. Soon a great variety of food is brought into the kíva by women and girls and placed on the floor. The inmates of the kíva group themselves around it and enjoy the supper, which has been provided by the families of the participants in the ceremony, and which is seasoned and flavored by a lively conversation, by jokes, and laughter, of which the Hópi are very fond.

\section{SECOND DAY. \\ SHUSH TÁLA. (ONCE DAY.)}

The women who, of course, have slept in the kiva, arise between four and half past four o'clock in the morning. As soon as they are awake they commence to practice singing, some sitting up, some still lying down. Some continue to sleep as long as they are permitted to do so. A few of the other women, with Masátoiniwa, seat themselves in front of the altar and sing a few songs, though this is so informal that it can hardly be called a ceremony. They are songs to the dawn and the morning and are sung on the morning of the second, third, fourth, fifth, and eighth days.

At about five o'clock, when all are up, a little ceremony takes place, called "kúivato." The women take their corn-ear "mothers" and a pinch of sacred meal and pruceed to a rock south-east of but close to the village, the chief priestess leading the column. Here they form in a line, facing the east. They hold the sacred meal to their lips, whisper a prayer on it, and then throw it towards the east, where the qöyángwūnūptū (white-rising or dawn), or sometimes the sikángwūnūptū (yellow-rising or dawn) may be seen illumining the sky. The novices also deposit one of the four nakwákwosis which they received with the head scratcher the previous day. All then silently return-Ngósi again heading the line-to the kiva, where they replace their corn-ears on the floor near the altar. This rite of kuivato takes place in all Hópi kíva ceremonies, so far as I know, though varying 
somewhat in form. The name signifies "(I) go to see" (or "to look," "to behold"). Just why this performance is so termed nobody has thus far been able to tell me. But as the ceremonial performances in the kiva are, as a rule, not supposed to begin before the appearance of the morning dawn, the dawn is often spoken of and watched in the kíva. Not infrequently some one will be told: "Um aokúivato" ("Go and see, look")! Whereupon one thus instructed will ascend the ladder to see whether it is already dawning. While this is, of course, entirely informal, the little rite described above might be taken as a formal ceremonial, going to behold or to see whether the morning dawn has appeared. In this rite all are supposed to participate. With it is connected a little prayer-offering to the precursor of the sun, the dawn, and also to the sun itself. The men usually perform this rite closer to the kiva. When I asked one of them what they prayed, he said they usually uttered a short prayer to the dawn and to the sun, saying: "Táwa ínaa, ókiw yókwani púu ítam híkwyani" ("Sun, my father! oh (make it) rain, and we shall drink"). I have noticed several times that women who happened to be absent when the others performed the rite of kuivato afterwards performed it alone, but close to the kíva.

Having returned to the kiva the women usually go to their homes to attend to their household duties and to prepare the morning meal. Some return to the kiva sooner, others later. When the sun rises $\mathrm{Ng}$ ठsi turns the sun slab on the altar around so that the side showing the drawing of the moon, which had been turned forward during the night, is hidden from view, and the sun symbol shown during the day.

At about seven o'clock Masátoiniwa, Hómikini, and Ngôsi prepare some prayer-offerings as follows: Masátoiniwa five pahus (roads), Ngósi five, and Hómikini seven nakwákwosis. ${ }^{1}$ When they are done they are placed on a tray and all three smoke over them. This is one of the few occasions on which Hópi women smoke. The smoke is blown on the tray. After the smoking, $\mathrm{Ng} \delta$ si takes the tray in her hands, Masátoiniwa a mósilili (tent or cone-shell) rattle, Hómikini a gourd rattle, and the three then sing the following over the tray, waving the tray and the rattles to the time of the singing:

I.

$$
\begin{gathered}
\text { "Yayayowayā, yayayowayā, } \\
\text { Yahayoway yahahayoway, } \\
\text { Owayā owa owayā.". }
\end{gathered}
$$

1 This, bowever, has been observed on this day only once, and hence I cannot say from personal observation whether always just this number is made. I am told that each one makes one nakwảkwosi for each world quarter, Masatoiniwa also one for the earth or sand, because he belongs to the Sand clan. Ngốsi does the same; Homikini, one for the snakes and one for the lizards, because he belongs to those clans. One he made for the sun, which, however, he says is sometimes made ty Masảtoiniwa. 
i 8 Field Columbian Museum-Anthropology, Vol. Vir, No. I.

II.

"Pohohohoolaina,

Poooolaina, Poooolaina;

Pohohoholaina, Pohohoholaina

Ayaywaitawaita ciyano

Ayaywaitawaita ciyanohay."

Both songs are chanted a number of times. As the language is - not Hópi I was unable to ascertain the meaning. They are undoubtedly fragmentary parts of old songs. All three put some meal on the tray, whereupon it is placed on the west side of the altar. Breakfast is then eaten, Ngס̊si fasting all day, the others abstaining from meats and salted food. After breakfast, four girls are directed to put on their ceremonial blanket (at $\delta 0 \ddot{)})$ and are then sent out with the prayerofferings just described, one to the north, another to the west, the third to the south, and the fourth to the east side of the village, where they lay thein down at prescribed places, ${ }^{1}$ sprinkling a little meal on them after they have been deposited.

During the day most of the women are generally in their houses. Some, however, engage in making baskets in the kíva. The novices grind corn the first four days for their godmothers, who in turn make trays for the novices, or in some cases, though seldom during the first four days, instruct the latter in the art of basket-making. The baskets made during the ceremony are used in, the puplic performance on the ninth day and are made in a great variety of designs. Those made by the beginners are usually small and far from being elaborate.

While the women are thus engaged in the manufacture of trays the two men either get wood for the kiva or do work in their homes. When in the kiva they smoke or eat occasionally. Now and then children are initiated; the larger ones receive the proper number of nakwákwosis and all the usual corn-ear "mother"; but head scratchers, I am told, are given on the first day only.

All eat in the kiva; even the girls who grind corn in the houses come to the kíva for that purpose. Again no meat or seasoned food is eaten.

"On the north side, in a shrine called "Kuiwanva," on the west side at a shrine called "Nuvatikaovı (Snow Hight)," on the south side near a bush at the edge of the mesa, on the east side at a place, half-way down the mesa, that has no special name. 
THE LIBRARY

OF THE

UNIVERSITY OF ILLINOIS 

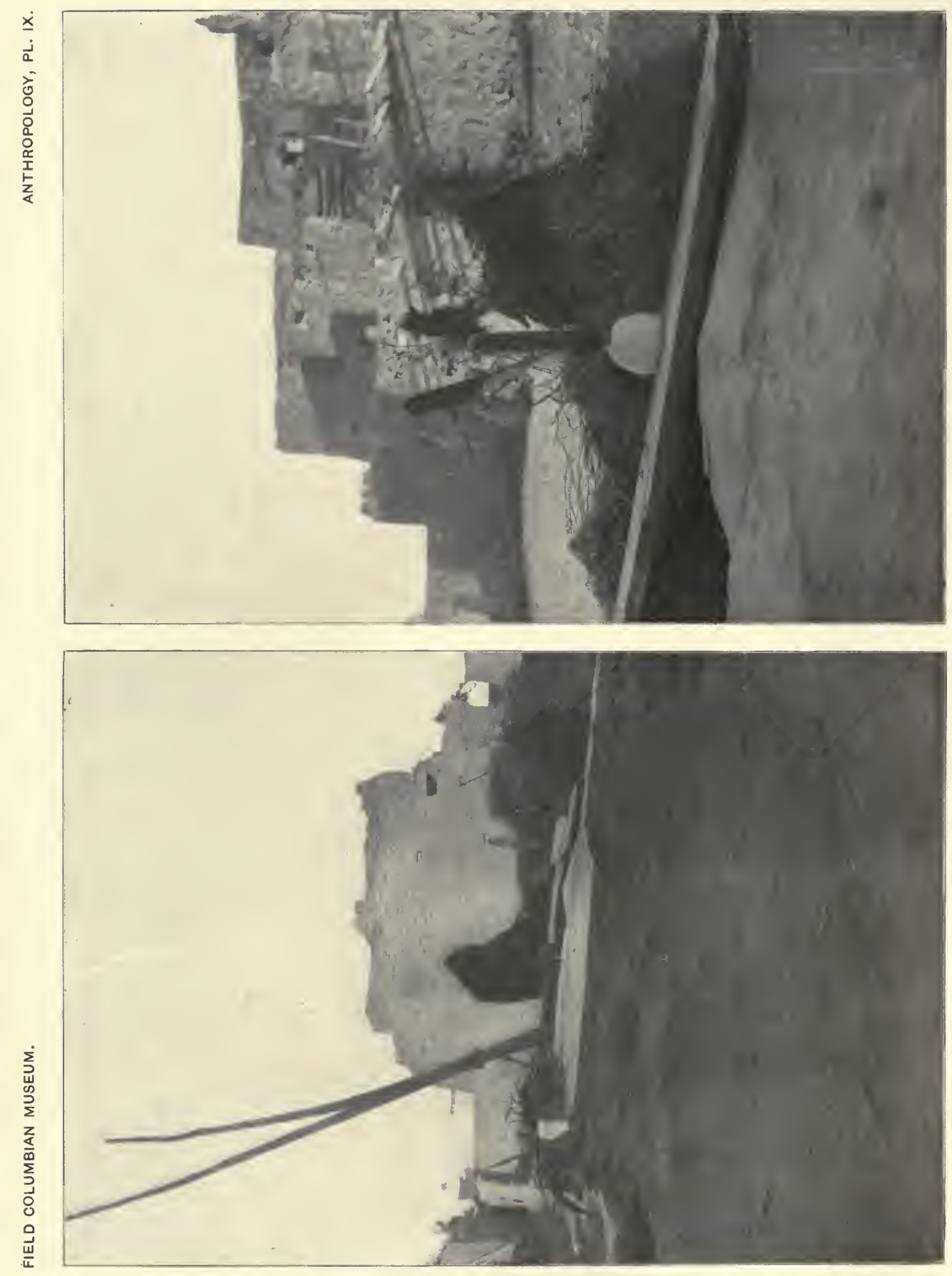


\section{PL. IX. THE NátSI OUTSIDE of the Kíva.}

This natsi, or society emblem, is made during the fourth day, and placed outside of the kiva, at the south end of the hatchway, early in the morning of the fifth day. It consists of a clay pedestal, into which is inserted a yellow ear of corn, two eagle tail feathers, and a little twig of an herb. South of the kíva is shown some brush which is used as fuel in the kiva. 


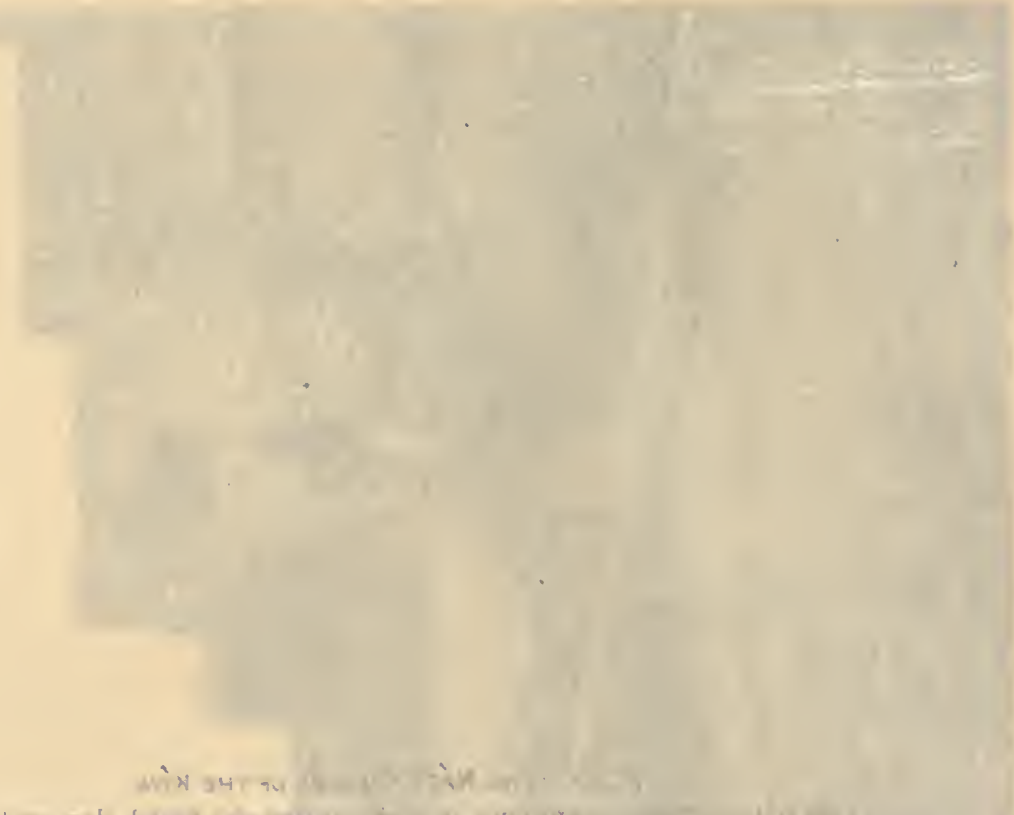

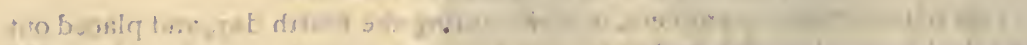

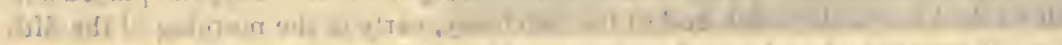

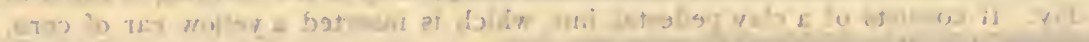

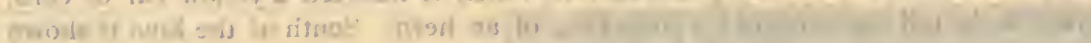

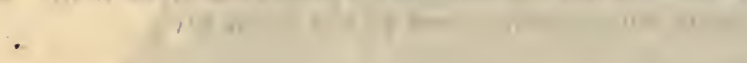




\section{THIRD DAY.}

\section{LÖSH TÁLA. (TWICE DAY.)}

This day is spent in essentially the same manner as the previous day. The novices deposit the second of their four nakwákwosis; all make the usual morning offering (huivato). The leaders make the usual "roads" and nakwákwosis which are deposited on the four sides of the village; ${ }^{\text {b }}$ basket-making is going ón in the kiva throughout the day, etc. All are expected to eat in the kíva, and while in a general way the three "meal times" - morning, noon, and-night-are observed, more or less eating is going on all day, singly or in groups. When the novices are in the kiva and not at work they usually sit at their assigned places on the floor in the east side of the kiva. On one occasion I noticeo that Ngósi rubbed into the faces of all present a little of the yellow powder which she used for that purpose in the singing ceremony. I am told that she does this every day.

The fasts are observed on this and the following day in the same manner as on the previous day.

\section{FOURTH DAY. BAYÍSHTALÁ. (THRICE DAY.)}

This is again one of the more important days of the ceremony. In the morning the usual rite of kúivato takes place, the novices deposit their third nakwákwosi, the three leaders again make prayerofferings, which are deposited outside of the village ${ }^{2}$ by four novices, etc. More women come in this day; each new-comer first sprinkles a pinch of corn-meal to the altar. Ngosi brings into the kiva a sprig of cúowi (Rhus Trilobata, Nutt), two bald eagle tail feathers, and a yellow corn-ear, for the new nátsi that is put up this day. Masátoiniwa makes four nakwákwosis of sikátsi (fly-catcher) feathers, ties them to the sprig, and the latter is then, tied together with the eagle feathers and corn-ear, the whole thrust into a clay pedestal, the latter colored with some sunflower blossom powder, and then this new nátsi is placed east of the altar to be put later outside and at the south end of the hatchway. (See Pl. IX.) Masátoiniwa also made a double green báho about six inches long, to which he fastened a cotton string "road," about three feet long, which he moistened in honey, rolled in corn-pollen, and to the end of which were fastened a large eagle breath feather and

${ }^{1}$ But this day somewhat closer by, on the north side at Acbámali (a shrine), on the west side at Tépchocbmo (greasewood knoll), on the south side near a small bluff, on the east side at Tcöokáyahantingwa (the place where clay is dug out).

2 North: Tokóonavi; representing the Navajo Mountains; west: near a trail at the edge of the mesa; south: at a rock called "Tukvishahpukpu" (broken or caved-in bluff); east: at the edge of the mesa near a trall. 
some sikátsi feathers. He wrapped the báho into a corn-husk and placed it on the floor on the east side of the altar.

Basket-making is going on throughout the day, in which even Ngơsi sometimes participates, as, in fact, she does every day. I again noticed on one occasion that Ngósi rubbed some of the yellow powder into the faces of all present. Occasionally some of the women form a circle and practice the singing and dancing for the plaza performance on the ninth day. A good deal of singing is also done by the women while they are at work making baskets.

Hómikini brings into the kíva some time in the forenoon a small, green corn-stalk and some vines and runners of beans, melons, squashes, etc., which are hung on the altar on each side.

Soon after dinner the leaders begin to renew the altar. Ngơsi removes the objects from in front of the upright frame and sweeps up the sand, which is eagerly divided up among the women in the kiva, who either.put it on the piles of sand in which they keep their basket willows moist or take it home, where it is sprinkled on the floor at the places where the corn is to be piled up, or, where it already has been brought in; the sand is put on the floor close to the corn.

Ngósi also ties two small trays to the two sides of the upright altar frame, which have been made by herself, ties nakwákwosis to the necks of the birds, places the newly made natsi in front of the bátñi and otherwise rearranges the objects in front of the altar.

Masátoiniwa has in the mean while made four nakwákwosis and one "road" of hawk feathers. On one occasion I noticed that he had tied with the latter a few small sikatsi feathers. Between two and three o'clock Ngósi puts on her atőö, takes these prayer-offerings, some meal, a móngwikuru, bone whistle, buzzard feather, and a little honey, and after Masátoiniwa has tied the nakwákwosi from the mónwikuru into her hair, she again goes to the spring Lánva and gets some water, in the same manner as on the first day. The little singing ceremony by Masátoiniwa over the objects brought back by Ngơsi is the same as on the first day. I am told that he sings the following song, which he repeats several times:

Cihiihiiicaka

Cihiihiiiihicakoýā

$\int^{\prime}$ This is sung twice.

Āhānainukiya

Porororoka

Kaaochanoma

Kaaakuruka

Cihiiiihiiiicako

Cihiiiihiiiicakoyayayā.

This line is sung to the north. This line is sung to the west. This line is sung to the south. 'This line is sung to the east. 
This song, as so many in Hópi ceremonies, has found its way to the Hópi from the Pueblos in New Mexico. Some of these songs are not understood at all, some, like this one, only partly.

After thus consecrating the water brought in by Ngósi, Masátoiniwa discharms her in the same way as on the first day, whereupon she disrobes and assists in the preparations for the approaching ceremony.

During her absence, Masátoiniwa has sprinkled fresh sand on the floor and removed the cloud picture in front of the altar. His wife, who belongs to the Agave clan, which is one of the clans ${ }^{1}$ that owns the fire, and Hómikini make each a nakwákwosi and place the same as on the first day. The members of the Agave clan also often place a little food near the fireplace before eating.

New participants have in the meanwhile been coming in, each one bringing her corn-ear "mother" and some sacred meal which she sprinkles on the altar. When Masátoiniwa has completed the cloud symbol picture Ngósi puts the medicine bowl, cloud symbols, birds, etc., in their proper places and puts the last finishing touches to the altar in general.

Some of the women continue to make baskets until the ceremony is about to begin. Others form little groups here and there around a watermelon, píki tray, and food bowl, and enjoy a luncheon. Little keléhoyas (novices) are still passed through the mohóngöla, in the manner already described.

At about half-past three o'clock all arrange themselves around the altar, Ngósi sprinkles meal and Masátoiniwa corn-pollen from the típoni to the ladder, as on the evening of the first day, and then follows exactly the same singing ceremony with the attendant performances during the different songs as on the first day.

When the ceremony is over, most of the participants leave the kíva. As a rule, the girls go out. first. Some return sooner, others later. Those who are in the kiva generally spend the time, until the evening meal is brought in, practicing the songs and the peculiar accompanying gestures of the hands for the public performance on the last day. For the evening meal all assemble in the kíva. Every one brings her share of food, places it on the floor, all seat themselves around the common board and eat the victuals, that have been brought together, in common. They consist of píki (a thin wafer bread, baked in large sheets, but folded together), peaches, watermelons, stewed

1 In the new year ceremony, which is controlled by the Agave clan, and which takes place in the Agave kiva, new fire is made with sticks and dry cedar bark early in the morning. The same is done in certain ceremonies of the Horn Society. 
squash, popped corn, stew, various kinds of mush, different dishes of meal, etc.

During the following night no one is allowed to sleep, ceremonies taking place several times during the night. The performances of this evening and night, however, have been observed one time only. My notes run as follows:

Nothing of importance took place during the evening until twelve o'clock. It was spent mostly in practicing for the public performance, which was relieved by intervals of gossipping, joking, and eating.

A third man, Yéshiwa, the husband of the chief priestess, had come in towards evening and spent the night in the kiva. Also a number of women and girls, who had not yet been present had put in their appearance, so that about forty persons were present during the night.

\section{FIFTH DAY.}

\section{NALÖSH TALA. (FOUR TIMES DAY.)}

From twelve o'clock to half-past twelve in the morning, the condition of affairs in the kíva was the same as before twelve o'clock; a free conversation throughout the kíva, here and there small groups around a watermelon, píki tray, or food bowl, etc. From half-past twelve until one in the morning, all formed a long circuit, facing its center and moving slowly sideways, again practicing the songs, motions, and dance to be performed on the plaza the last day. At one o'clock all the novices were sent home, as they were said to be too young to witness the costuming, etc., about to take place. When they had left, the objects in front of the altar frame (birds, medicine bowl, cloud symbols, figurines, etc.,) were placed on the floor near the fireplace, and Masátoiniwa and Talásngainöma were dressed up for the ceremony to take place in which the first was to represent Múyingwa, the God of Germination and Growth, and the latter, Nayángaptumsi, the Goddess of all kinds of seeds. The body decoration of Masátoiniwa was as follows: The lower arms, lower legs, a band running from shoulder to shoulder, another band running around the body over the abdomen (each from two to three inches wide), and a narrower band around the leg over each knee were daubed white; his chin was painted black by Ngósi. His costume consisted of the usual ceremonial kilt and sash, ankle bands, fox skin, bandoleer, and leg bands of strands of darkblue yarn, many strands of beads, turquoise ear pendants, and a kwáchakwa (bunch of white eagle breath feathers), on the apex, a single nakwákwosi-taken from the móngwikuru-on the front of the 


\section{THE LIBRARY}

OF THE

UNIVERSITY OF ILLINOIS 


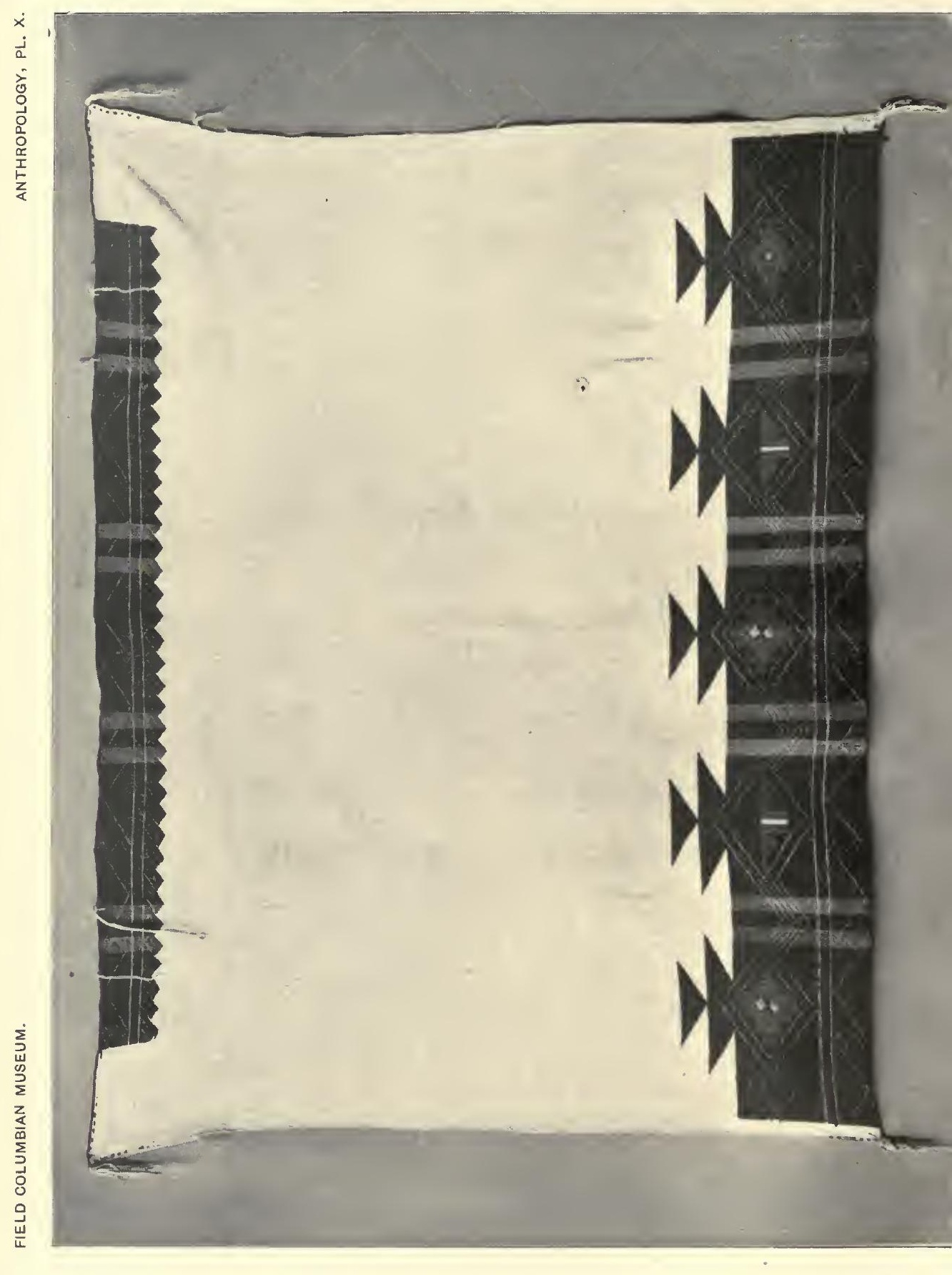


PL. X. THE TUIHI.

This robe is used by certain personages in many of the extended Hópi ceremonies, also by certain Kateinas. In this case it forms a part of the costume of the Oáqöl-mánas. The body of the robe is made of cotton, the embroidery work is done with wool. In the lower borders may be seen three symbols of blossoms, representing the blossoms of melons, squashes, herbs, and fowers, etc. Two of the figures of the border represent the hókona, a large butterfly that figures in many of the Hópi ceremonies. What the five double triangular shaped figures of the top of the lower border mean, no one has thus far been able to tell me. It is not unlikely, however, that they represent nakwáwosis (prayer offerings) of turkey feathers. The meaning of the white lines in the two borders and all the perpendicular stripes have as yet not been ascertained, either. 


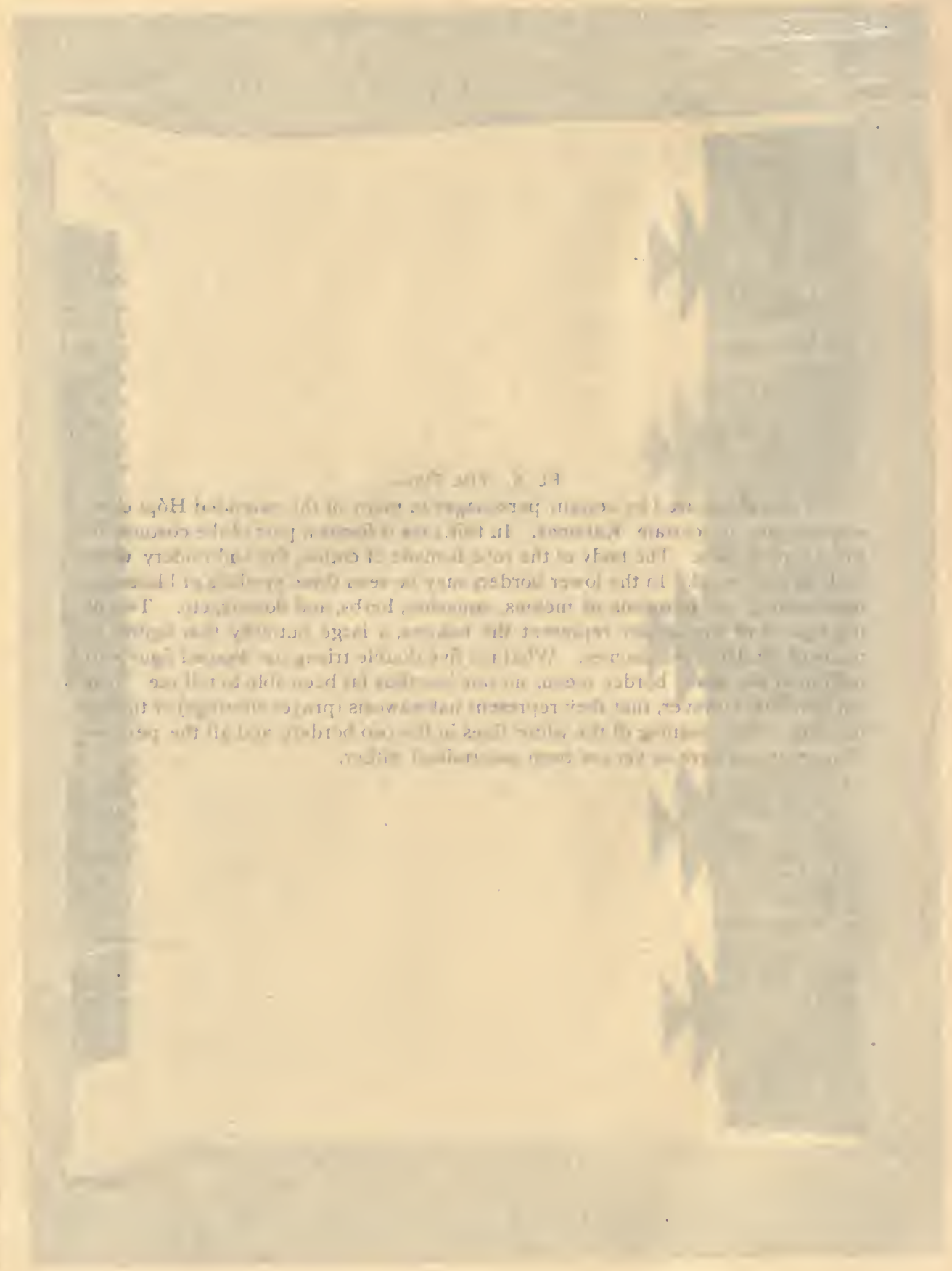


head. To his right wrist he had tied an old bell. ${ }^{1}$ The woman had white forearms, white feet, and her chin was also daubed black by Ngósi. She wore her regulation dress, but over it, in the form of a dress, the large embroidered ceremonial blanket (táihi) (see Pl. X), and over this, on the upper part of her body, an embroidered katcina kilt, which was folded under her right arm and the two ends tied together over her left shoulder and on her left side. The táihi dress was held in place by a white, knotted wūkókwãva (big belt), which was tied on her left side. In her ears she wore a pair of túoynahkas (square ear,pendants, inlaid with turquoise) and on her head a nakwákwosi, also taken from a móngwikuru. Around her neck she wore numerous strands of beads from which was suspended an abalone shell, around the ankles figured katcina ankle bands, and to her left wrist she had tied an old bell.

As soon as they were dressed they went behind the altar frame, where they waited until the novices had been called and seated at their usual places on the floor in the east side of the kiva. It was now two o'clock in the morning. When all were seated, the women began to sing, whereupon the two emerged from behind the altar. Masátoiniwa held in both hands a netted wheel about twelve inches in diameter. This was, as nearly as I could make out, of the same pattern as the wheels used on the last day by the two Oáqöl manas, consisting of a wooden ring about three-quarters of an inch thick, which was filled with a network of small meshes, leaving a small opening in the center. This is called "báchaiyanpi" (water sieve), because the cloud deities have such strainers through which they sift or drop the rain. The women held in both hands a common pota. ${ }^{2}$ The two performed a peculiar. jumping ${ }^{3}$ dance, forward, backward, and sideways, first before the altar, then in front of the novices, always waving the objects they held, up and down (as a wish, it is explained, that they, the novices, may grow old), and from one side to the other and towards the novices to the time of the singing. Having danced before the novices a while they retreated to the altar, danced there, then again in front of the novices, etc., dancing six times at both places. Hereupon they handed the two objects to two women, who said, "Askwali" (thanks)! The singing stopped and the two actors disappeared behind the altar.

In a few minutes they emerged again from behind the altar, the

A number of these bells exist in Oraibi. They vary in size from two to six inches high and are used in different ceremonies. Until a few years ago they were in charge of the Kwan (Agave) chief priest, but owing to a quarrel between the liberal and conservative members of the order, they have nol always been returned of late years when being borrowed for use in ceremonials.

A basket tray, made on the second mesa.

${ }^{3}$ I am told the jumping on the floor is to serve as an announcement to Múyingwa, the God of Growth, who lives below, that the ceremony is in progress. 
man from the west, the woman from the east side, and repeated the same kind of a dance. This time, however, Masátoiniwa held a. móngwikuru in his right, a bell in his left hand, the woman the típoni in her right and also a bell in her left hand. The objects are waved to the time of the dancing, but not towards the novices. The two danced in front of the row of the novices, first southward, then northward, etc., four times southward and four times northward in all. When done, they handed the objects to Ngósi, who said, "thanks," and replaced them on the floor. The two withdrew behind the altar frame, where they removed their costumes.

It was now a quarter-past two o'clock in the morning. While the two dancers washed off the paint from their bodies, Ngosi replaced all the objects in front of the altar, whereupon the leaders seated themselves at their usual places, south of the altar, the other participants behind them in the deeper portion of the kiva, and the singing ceremony that took place the previous evening and on the first day was repeated, as far as I could judge. As it was almost entirely dark in front of the altar I could not see whether the different performances during the different songs (with the corn, birds, etc.) took place as usual. But as the four meal lines were made and the cloud producer used, I infer that the assurance given me, that the ceremony is the same as the others, is correct.

'The novices remained in their places during the performance. Yéshiwa and Hómikini sat at the fireplace and smoked, the latter also keeping up the fire. At the conclusion of the ceremony all said, "'Áskwali"' (thanks)! Ngósi, I think, uttered a short prayer, and then a recess was taken, which was again spent in eating, with very lively conversation and much laughing. ${ }^{1}$

While, as already stated, the performances from twelve o'clock in the morning, on, as just described, have been observed only once, those now following have been studied twice. After a recess of fifteen or twenty minutes Ngósi distributes the different objects from in front of the altar frame among the participants. The medicine bowl, bone whistle, and aspergil she gives to the sprinkler, the Oáqöl-mana figurine is supposed to be given to some one of the Sand clan, the corn-ears to one belonging to the Pihkash clan. But if formerly the same objects were always given to certain persons, or at least to members of certain clans, such is no longer the case, as the following instances may show:

${ }_{1}$ While in ceremonies attended principally by men, as a rule, a free and unconstrained intercourse prevails during the intervals when no ceremonial performances take place, the talking, laughing, and joking seems to be much more free in women's ceremonies, always, however, within the bounds of propriety. 
Masátoiniwa had a gourd rattle and báho in 1897 ; a mósilili and honey pot in rgor.

Hómikini had a mósilili in 1897 ; a gourd rattle in Igor.

Yéshiwa had a tobacco pouch and pipes in 1897 ; a meal tray in rgor, etc.

When everything (as far as I could see) that is not attached to the altar frame is distributed, Ngósi, taking the tiponi, takes a position in the south-east corner of the deeper portion of the kiva; a girl with the Oáqöl-mana figurine stands behind her; another girl with the new nátsi to her left. The sprinkler stands northeast of the fireplace. All stand in the deeper portion of the kiva between the altar and fireplace, facing to the south-east of the kiva, which, from the position of the kiva, would be to the place where the sun rises. A long song is then sung, during which all wave the objects which they hold, consisting of altar accessories, bells, rattles, corn-ears, etc., towards the direction mentioned. The sprinkler whistles into the medicine bowl and asperges with the aspergil six times, I believe. I have been unable to settle the question whether several songs are chanted or only one, repeated several times. Masátoiniwa claims the latter to be the case, but he is old, his knowledge of the Oáqöl songs is sadly lacking, and it is difficult to get any systematic information from him. He dictated me the following song as the one being used. It has, like many other Hópi songs, two parts:

\section{DOWNWARDS.}

Māāhāaamāhāaayahaiahai !

Māāhāaamāhāaayahaiahai!

Conway qöyangwunkuiwahai.

Conway sikangwunkuiwahai.

Māhāahahahaiahai.

Māhāahahahaiahahā!

(The, above prelude is repeated.)

\section{UPWARDS.}

Yupavö taalaokuiwaa!

Yupavö taalaáokuiwaa!

Tuvevolimanatu.

Qöyavolimanatu, Hao!

Shoshoko hihtaa yawoma hao

'luvevolimanatū.

Qöyavolimanatu Hao, hao! 
26 Field Columbian Museum-Anthropology, Vol. Vi., No. I.

(The prelude then follows as a conclusion and the whole song is repeated several times.)

TRANSLATION.

There! ${ }^{1}$

There!

Beautiful white rising has dawned.

Beautiful yellow rising has dawned.

There!

There!

Go (the) day has dawned.

Go (the) day has dawned.

Figured butterfly maiden, ${ }^{2}$

White butterfly maiden, ${ }^{3} \mathrm{HaO}$ !

Everything (and anything) bring, ${ }^{4}$

Figured butterfly maiden,

White butterfly malden, Hao, hao!

When the performance is over everything is replaced, whereupon Talásngainöma takes one of the crooks and some corn-meal and joins Ngósi, who has remained standing in her place. Both then leave the kíva and stop outside, about twenty feet from the kíva. Ngósi first holds the meal to her lips and then sprinkles some on the ground, some towards the east. Hereupon she waves the tiponi in the same direction, and then holds it to her breast. This she does three times. Talásngainöma hereupon sprinkles her meal and then both re-enter the kiva, where they resume their position in the south-east corner of the deeper part of the kíva, but now facing southward. Ngơsi utters a prayer, which was spoken in such a low tone and so fast that I could not record it at the time, but which one of the leaders says is about as follows:

"Pai hápi ítam yep shúan pasíonaya. Ítam it itáh máksoni akw pas pai móngwactūtini; yáhpio ítam shópkawat sínom yéshwani. Pai háhlaikahkango, öokaokahkango!" (And now we worship here, just of one mind. We by this our effort must bring this to a conclusion

I The word "mā," of which a whole line is formed, is an exclamation something like "there!" "there nowl" "do you see?" etc.

"The term "tuvévolimanatu" is used as well for smaller girls (referring to their hair whorls) as for young corn-stalks. But as this is evidently not the complete song, it is difficult to decide which is meant, but probably both.

"See previous remark: "Qöyảvolimana" refers to larger maidens and larger corn-stalks than "Tuvévolimana."

4 Refers in the first place to the objects taken from the altar and waved during the singing. 
[referring to the ceremony]. After this we-all the people-shall live, yes happily, encouraged.)

Talásngainöma then says: "Pai hápi itam yep shúan pasionaya; káwuu ítam háhlaikahkang talóongnawicni." Shópkawat sínomu,. Pai háhlaikahkang öokáokahkang yeshní." (And now we here perform well. To-morrow we shall happily [cheerfully] have gone to the morning, all the people shall live happily [cheerfully] encouraged.)

Hereupon Ngósi touches with the típoni the breast of every keléhoya, even the babies held by their mothers, and utters a good wish. Tolásngainöma lets each one touch the crook ${ }^{2}$ and also utters a good wish or blessing, whereupon the two objects are replaced. All the corn-ears from around the medicine bowl are then placed on the floor before the altar, the two women kneel before them, bending over them, and singing in a low tone, being assisted by Masátoiniwa and Nakwámösi, Talásngainöma beating time with the corn-ears on the floor. Of the songs that are sung I have thus far been able to obtain two only; they are as follows:

\section{TO THE NorTH.}

Hahahaaahahaaao inguu, . Takurikahaö, inguuuhuu

Itaaham namaha

Tūwanahahashamiihiiahay.
Hao! my mother, Yellow corn-ear, my mother We together Go to Túwanashave. ${ }^{3}$

\section{To THE WEST.}

The same, but,

Sakwáputskahaö, etc.

$$
\text { Blue corn-ear, etc. }
$$

\section{To THE SouTh.}

The same, but, Páwalahakaō, etc.

\section{Red corn-ear, etc.}

1 I have not been able to fully satisfy myself as to the meaning of the somewbat obscure expres. sions "talöongnawicni" (we go to the morning) and "tảpkiwicni" (we go to the evening), which are so frequently used in Hópi ceremonies, especially when morning or evenıng is referred to in connection with an all-night or all-day ceremony. The meaning of the expression as given seems to be: Get through, go through, or continue until morning (or evening).

'The nátsi or society emblem of the Táo (Singer) Society is such a crook-the symbol of life, and on one of the days of the Wüuchim ceremony early in the morning all the inhabitants of the village file by this natsi, which stands at the south end of the entrance to the Táo kfva and touch it as a prayer for a long and prosperous life.

${ }^{3}$ Tứwanashave, earth (or sand) center, is first a traditional place in the earth; then a place south of Oráibi where the Badger and other clans once lived; and the name is also used, as in this case, for the center place on the sand in front of the altar on which stands the medicine bow!, the symbol of the sipapu, the sand representing the earth or world. 
28 Field Columbian Museum-Anthropology, Vol. Vi., No. I.

IV. To The EAst.

The same, but,

Qöyáwikahaö, etc.

White corn-ear, etc.

V. To the North-east (Above).

The same, but,

Kokómakahä̈, etc. Black corn-ear, etc.

Vi. To the South-west (Below).

The same, but,

Tawákchikahaö, etc. Sweet corn-ear, etc.

During the first stanza Talásngainöma picks up the yellow corn-ear and places it in her lap, during the second the blue one, etc.

The other song obtained is as follows:

I. To the North.

Inunānā, Inunānā

Haviraina

Hapi novāā

Kwihihingvi.

These lines are not understood by the Hópi; they are probably from one of the Pueblo Indian languages of New Mexico.

Kwíngvi, a tree having hard wood, used for axe handles, etc.

II. To THE West.

The same, but the last line:

Kahahavi

Kahávi, a willow; small sticks used for prayer-sticks, for hoe handles, etc.

III. To the South.

The same, but the last line:

Hohohongwi.

Hóngwi, a plant; stocks very straight; used for arrow and spindle shafts, etc.

IV. TO THE EAs'r.

The same, but last line:

Hohohohoshoi.

Hóchki, juniper-tree; used for firewood. 


\section{To The North-East (Above).}

The same, but the last line:

Shihiwahpi.

Shiwáhpi, a grass, used for windbrakes in the field, for trays, etc.

\section{To the South-west (Below).}

The same, but the last line:

Tühuhushiwahpi.

T'úshiwahpi, a smaller variety of shewahpi; used for windbrakes.

After the singing, Talásngainöma replaces the corn-ears around the medicine bowl. Masátoiniwa explains that, as Múyingwa is the Grod of Germination and owns the corn, the corn-ears are, as it were, obtained anew from this deity by these songs and then placed back again around the bowl, where they represent the corn. This forms by far the greatest part of the Hópi food, for which reason the Hópi in so many songs and otherwise call the corn-ears "mother."

The different kinds of wood and plants mentioned in the second song are used by the Hópi and their growth controlled by Múyingwa.

It may be proper to remark, that the handling of the corn-ears and aspergil, during the ceremonies, by a woman of the Sand clan is irregular. It should be done by one from the Young Corn, Cloud, or related clans, but I was told that the old woman, Nacílāvi, who belongs to the Cloud clan and who used to "perform these duties, no longer participates, and that another suitable person has not yet been found.

After this little rite was finished, most of the women practiced singing until about half-past four o'clock in the morning, during which some of the younger members and novices fell asleep, all efforts on the part of the older ones to keep them awake notwithstanding. At the time mentioned, the women went out as usual to perform the rite of kúivato, but it seems they did not all go out at the same time, and some at least performed the rite only a few yards away from the kiva. The novices, who have received nakwákwosis, deposit the last of these, and those having received head scratchers deposit these also, at a rock south of the village, on this occasion.

Hereupon the women bring water into the kiva in large bowls and also roots of the yucca plant (Yucca glauca), which are crushed with stones on the floor, and suds made of them in the bowls. While these preparations are being made the novices, who have been seated on the kiva floor most of the time, are now sitting on the banquette which 
runs along the east side of the kiva. A general head-washing now ensues, the godmothers washing their "children," no matter when they were initiated, and vice versa. The novices are also washed by their godmothers. ${ }^{1}$ Ngósi washed her own head and that of her husband Yéshiwa. The sanne I noticed one time of Masátoiniwa's wife. The little babies' heads are also washed. It was six o'clock when this head-washing was over.

It should have been observed before, that while the sacred ceremonies are in progress in the kíva, from about half-past twelve to about four o'clock in the morning, one or several men of either the Agave, Horn, Coyote, or Snake Societies is keeping watch outside of the kíva, which I have also noticed in the Soyál and Maráu ceremonies and understand is done in others, too.

When they are done they say to the novice: "Um woyómii úh katci návokaonakang wúhtihaskiwúwani! níkang n. n. um machiwa." (May you, a long time your life possessing, become an old woinan! but n. n. you are called or [named].) At about half-past six in the morning Ngosi puts up at the south end of the kiva entrance the new nátsi made the previous day (see Pl. IX), waving it first from the six cardinal points and then sprinkling a pinch of meal on it.

After the head-washing, some rested, others practiced singing and dancing; the kíva was swept and at about half-past seven, breakfast was partaken of by all participants in the kiva. The fast is now broken and all can eat any kind of food throughout the remaining part of the ceremony.

The novices no longer grind corn for their godmothers, but are supposed to learn to make trays on this and the following days, in which they are instructed by the older women.

This day is usually a "blue Monday" for the participating members of the Fraterity. Having been up all night they are wery tired, and the greater part of the day is spent in resting and sleeping. A little basket-making is done now and then in the kiva. While some of the women go in and out at the kíva, most of them spend the greater part of their time in their homes.

In 1893 and 1895 Masátoiniwa and Hómikini began to make some kaốbahos. These are sinall slabs, about seven inches long, two inches wide, and about seven-eighths of an inch thick. At the lower end they have a keystone shaped handle. (See Pl. XI.) They are made of báhko (cottonwood roots, lit.: water wood), of which almost all wooden ceremonial objects, used in connection with the Hópi ceremonials, are made.

${ }^{2}$ Usually all others who belong to the clan of the godmother also wash the head of the novice. 
I
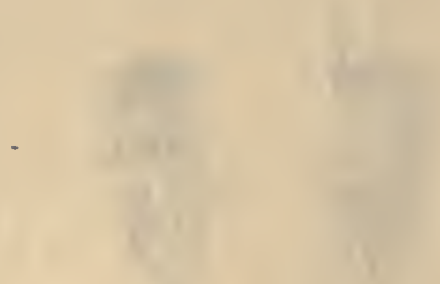

$$
\text { nos. }
$$

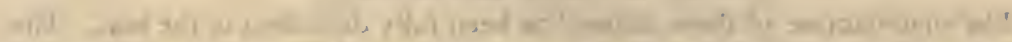

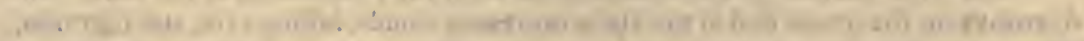

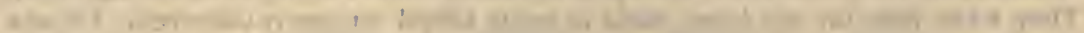

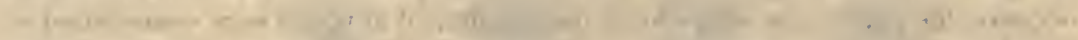

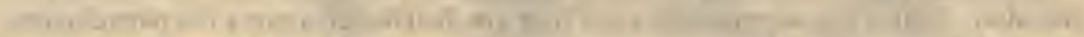

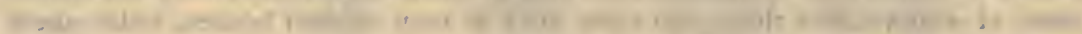

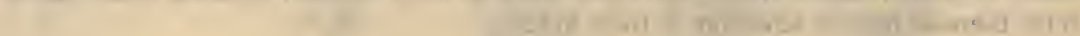




\section{PL. XI. KAÖ (CORN-EAR) BÁHOS.}

The manufacture of these báhos has been fully described in the text. The drawings on the upper end of the slabs represent clouds, falling rain, and lightning. They have thus far not been made in every Oáqöl ceremony observed. On one occasion the author saw sixty-one of them made, all of which were consecrated on the altar. After the ceremony is over they are distributed among the participants, some of whom insert them into their piles of corn in their houses, while others bury them as prayer offerings in their fields. 


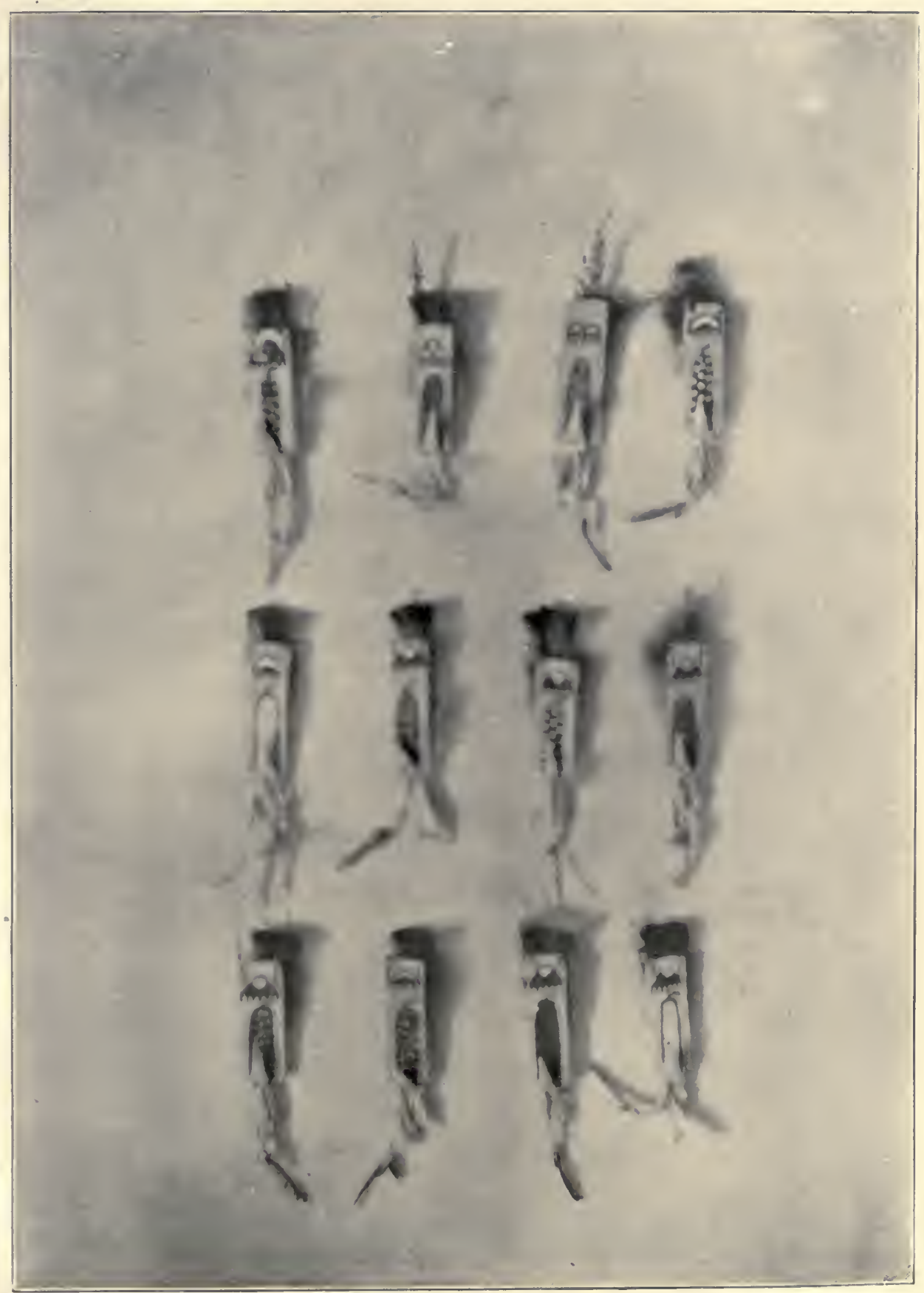




\section{THE LIBRARY \\ OF THE \\ UNIVERSITY OF ILLINOIS}


On this day, however, only the wood was cut into shape and smoothed nicely with sand stones. The paint was put on the next day. One báho is supposed to be made for each participant. In 1903 sixty-three were made, while in I 895 only a few, I believe, for the novices only. I have repeatedly asked why these báhos are not made for every ceremony, and have invariably received the answer: báhko shúlawe (water wood all gone). ${ }^{1}$

No fasting is done on this day, but the meals are taken in the kiva. Not all the participants, however, appear in the kiva for that purpose at exactly the same time. They usually eat in small groups, especially at noon. All who possibly can be away from their homes sleep in the kiva.

The altar accessories remain throughout the day in the disordered state in which they were left in the night.

\section{SIXTH DAY. \\ SHUSH KA HIMUUU.}

The sixth day is spent in essentialty the same way as the fifth. The men are out a part of the time, either getting wood or attending to work in their homes. In 1893 and 1895 a part of the day was spent in painting the kaobbahos. In the morning they were painted with white kaolin, which dries very quickly. About ten o'clock, both men put on their kilts and began mixing the other paints for the báhos, green, yellow, red, and black, in different stone mortars, and then painted all the báhos green, whereupon they decorated them with cloud and corn-ear symbols as follows, though how many of each kind my notes do not state:

$\begin{array}{lc}\text { Color of CORN-EAR. } & \text { COLOR OF } \\ \text { yellow } & \text { bots on CORN-Ear. } \\ \text { yellow } & \text { white } \\ \text { yellow } & \text { green and bjack } \\ \text { yellow } & \text { green } \\ \text { light green } & \text { white } \\ \text { red } & \text { black } \\ \text { red } & \text { green } \\ \text { white } & \text { green }\end{array}$

1 These cottonwood roots are obtained either from the Blue Canyon, about thirty-five miles, or from the Little Colorado River, about forty-five miles away.

2 This one had a cloud symbol over the corn-ear consisting of one semicircle with sliort, black lines running downward from its lower border indicating rain, and two zigzag lines running upward representing lightning. Of these only one was made. 
32 Field Columbian Museum-Anthropology, Vol. Vi., No. I.
black $^{1}$
white
black $^{2}$
green

It will be noticed that in decorating these báhos the five ceremonial colors, yellow for the north, green for the west, red for the south, white for the east, and black for above, are used. ${ }^{3}$

The relation between the colors of the corn-ears and the dots representing the kernels, is irregular. The order usually observed is, that where two colors are used together, either the color of the next cardinal point is used, for instance, green (west) with yellow (north), red (south) with green (west), etc., the ceremonial circuit being: north, west, south, east, north-east (representing above) and south-west (representing below), or the two colors of the opposite cardinal points are used together: yellow (north) with red (south), etc.

After all the báhos had been painted, Masátoiniwa tied to the obverse side of each one a small corn-husk packet containing corn-ineal and honey, and a nakwákwosi previously prepared by Hómikini. The báhos were then placed near the altar to be completed the next day.

In the afternoon the men were out a part of the time, attending to their duties.

It has already been stated that some baskets are made during the day. I noticed on several occasions that when women left their partly finished trays in the kiva they placed them on the altar, asperging them with a little water from the medicine bowl.

I have noticed that sometimes food is brought into the kíva on these days in the four ceremonial bowls, four mush trays and four píki trays. It is said that this is sent in for the novices by their godmothers, and also for the chief priestess, but there seems to be no rule about this matter.

\section{SEVENTH DAY. PÍKTOTOǨA. (PÍKI DAY.)}

This is another of the less important days of the ceremony. The men usually get some firewood, and in $\mathrm{r} 893$ and $\mathrm{r} 895$ they completed the kaôbahos by tying to the reverse side of each one a sprig of kúña

${ }^{1}$ This, of which also only one was made, had a similar cloud symbol, but of two semicircles, which were drawn side by side, and without any lightning symbols.

${ }^{2}$ One of this kind also had a cloud symbol, like the previous one, but a third semicircle was drawn over and connecting the two, and, while all the other segments were drawn in black outlines only, this last one was filled with a coat of white kaolin.

"The south is supposed to "own" all kinds (soyóhim) of colors. Thus, while in songs the first stanza speaks about yellow birds, flowers, corn, etc., the second about blue (green) etc., the sixth speaks, usually, about soyóhim (all kinds of) blossoms, corn, birds, etc. Where only one particular color can be used, for instance in stones, shells, etc., around the medicine bowl, a gray object is used, although this color seems to be then considered more as a mixture of colors than as a typical color. The corn-ear used for "below" is always a sweet corn-ear (tawákchi). 


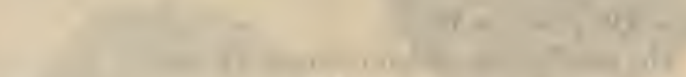

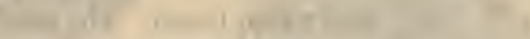
(The

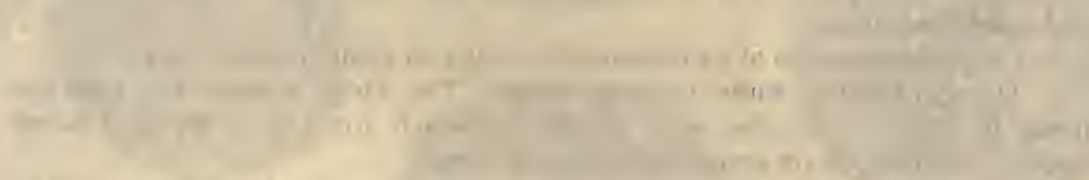

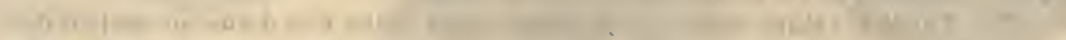

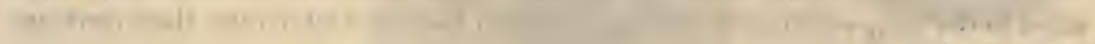

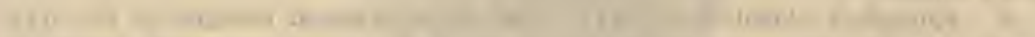

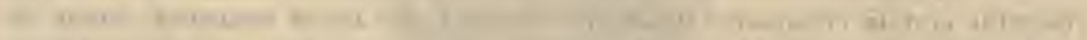

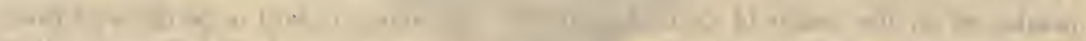

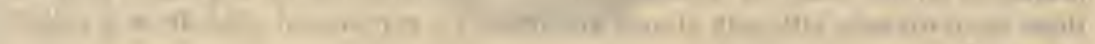

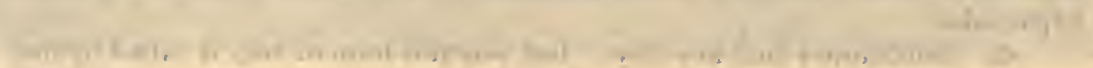

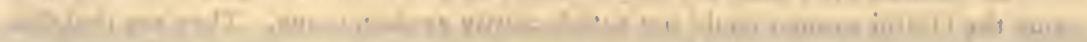

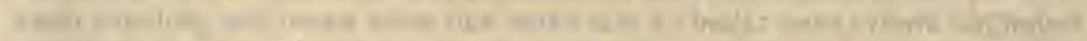

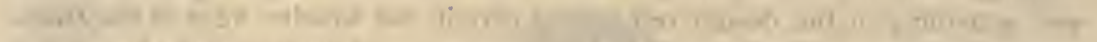

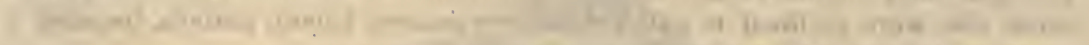

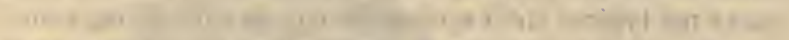
wey 1 a

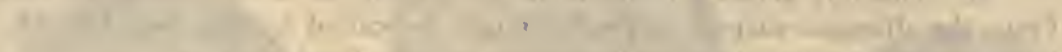

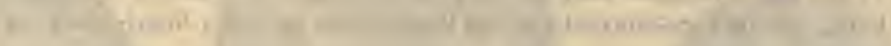
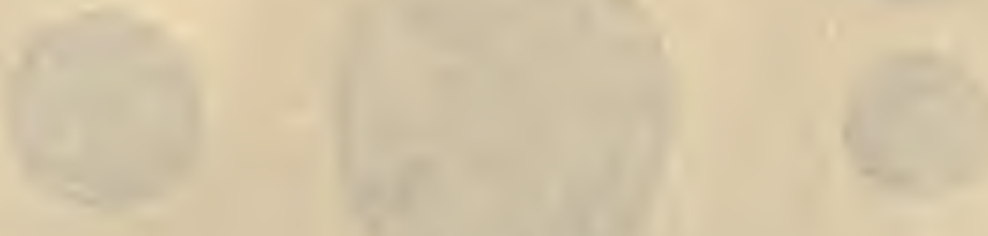
Pl. XII. Various Trays.

A. Morí (bean trays). The form of the design resembles a bean.

B. The design is not fully identified; it is probably a combination of a sling and head-dress tray.

C. A combination of an óhchok (filled in), and cómpi (tied to) tray.

D. Qöyápruru (white opening trays). The Hópi women say that the name is derived from the white in the eye which appears on the eyes being opened, and disappears upon the eyes being closed.

E. Tuwíhpi (sling tray). The name refers to the five diamond-shaped designs in the tray, which resemble the piece of buckskin which the Hópi boys use for their slings.

F. Kopáchok (head-dress tray). The terrace-shaped designs in the tray resemble certain ceremonial head-dresses used on various occasions, either on masks or on the heads of certain dancers. The name is said to be derived from these head-dresses, although almost any form of a ceremonial head-dress is called kapáchoki.

G. Sióhötahpi (Zuni key tray). Just why this form of tray is called by that name the Oráibi women could not satisfactorily explain to me. They say that this design has always been called by that name and some stated that probably there was something in the design resembling certain old wooden keys of the Zunis. Some also were inclined to call the pattern ómawu (cloud) pattern, because it shows the typical Hópi symbol for clouds with falling rain.

H. This tray shows a combination of designs, as is very often the case. From the diamond-shaped figures it might be called a sling tray, like "E." From the terrace-shaped figures it would be called a head-dress tray, like "F." 

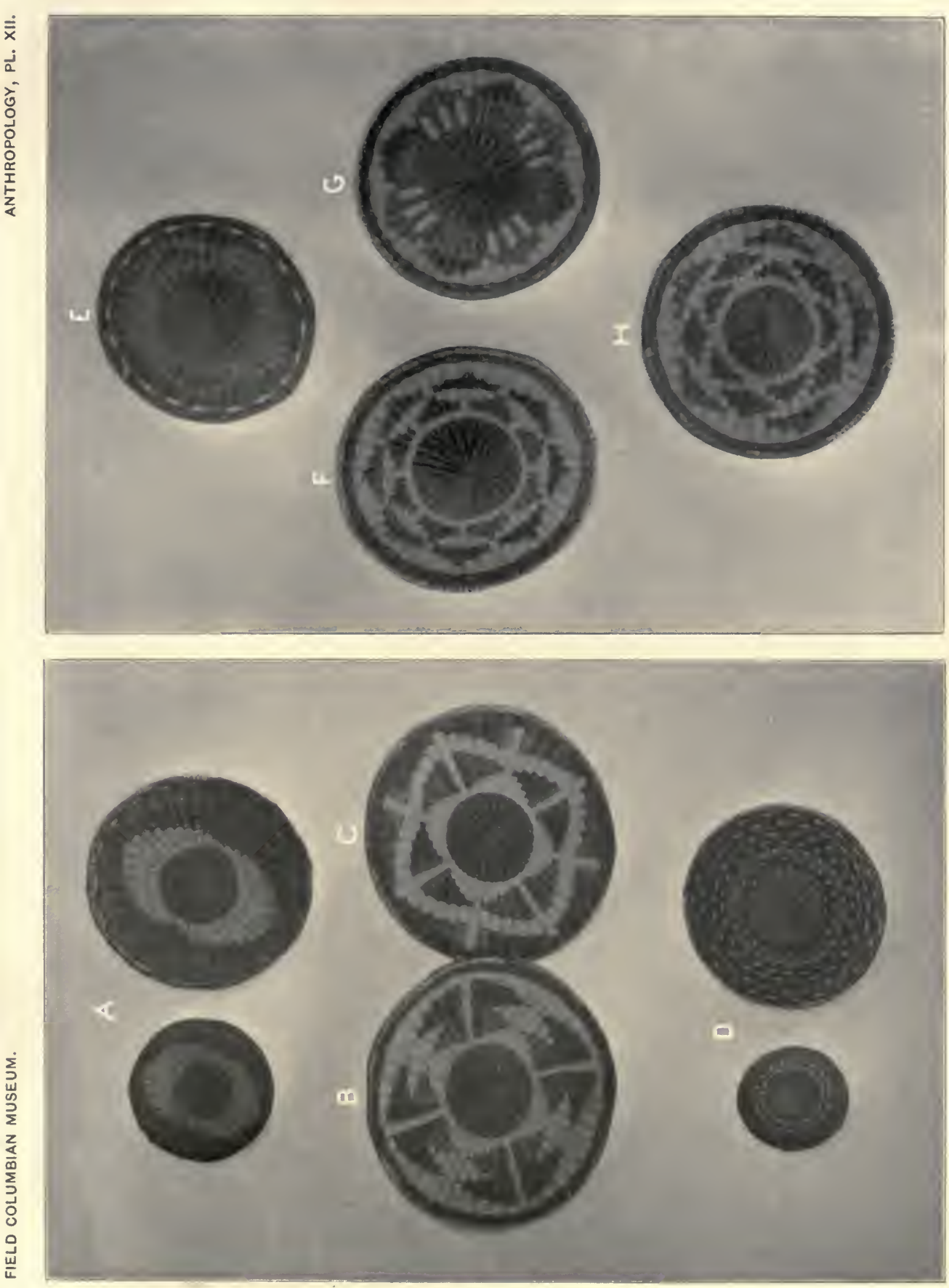
THE LIBRARY

OF THE

UNIVERSITY OF ILLINOIS 


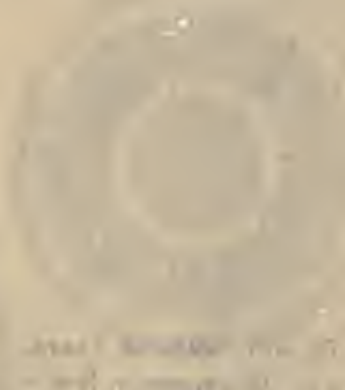

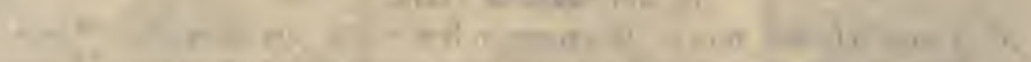
.

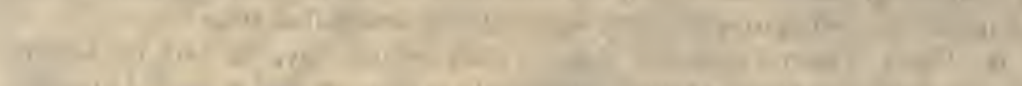

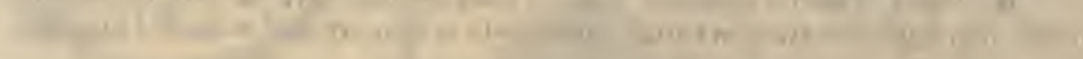

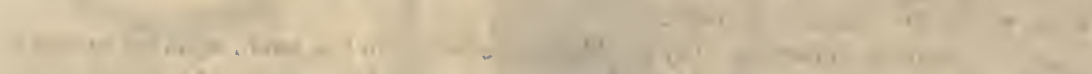

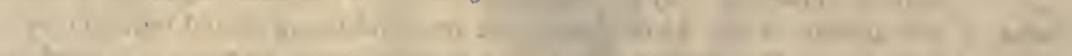

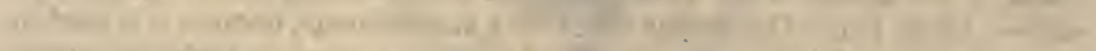

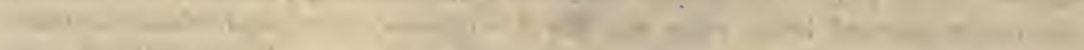

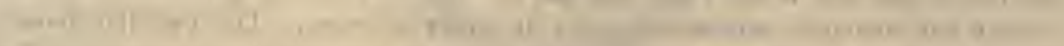

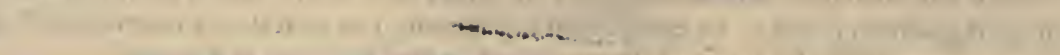

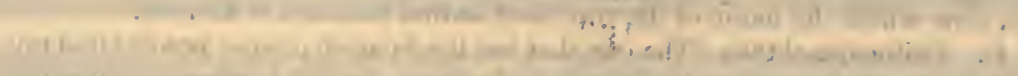

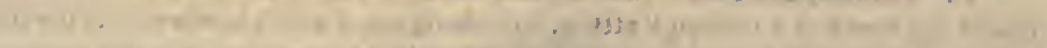

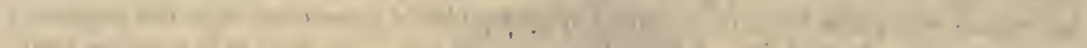

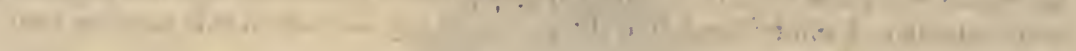

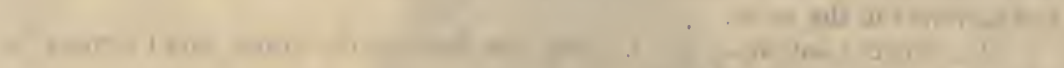

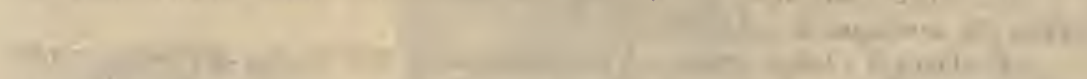

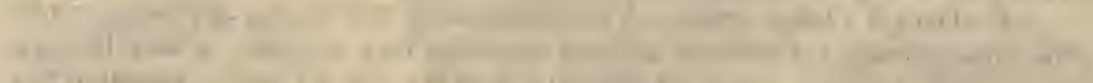

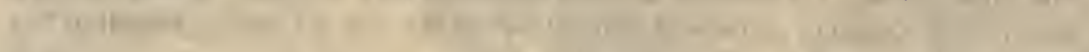

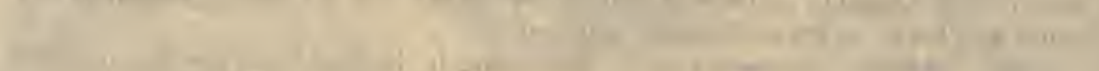

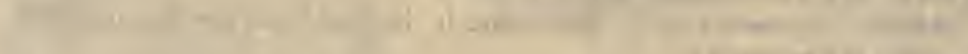

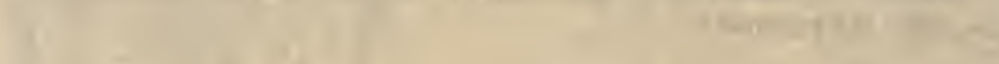




\section{PL. XIII. Various Trays.}

A. Cómpi (bound tray). The name refers to the junctures of the black lines at different places where they are said to be bound or tied together. From the diamond-shaped figures this tray is sometimes also called sling tray.

B. Cómpi (bound or tied). Like in the previous tray, the dark lines in the decoration join each other at certain places where they are said to be tied together, from which the name is derived.

C. Nángui (clasping tray). The name refers to the small squares running round in the middle of the white part of the tray and being joined together by a narrow black line. This tray is also called kongñáhompi, because it is used by the newly married bride when she fills it with sweet corn meal, which she takes over to her husband's mother, to whom she gives this meal. This peculiar manner of giving, which is not to be considered a payment, nor exactly a present, is called hóma, from which the name of the tray used on that occasion is derived.

D. Chilitoshmoktaka (The one that has the Spanish pepper powder tied up). This is the name of a certain Katcina, a crude figure of which is woven into the tray. In certain races this Katcina carries a little bundle of powdered Spanish pepper, a small quantity of which is put into the mouth of any one whom this Katcina beats and captures in the races.

E. Tcöb (antelope tray 1. The meaning of the three small figures between the antelopes is not known.

F. Oáckal (ledge tray). Various forms of this design are being made. The name refers to the different layers of earth and rock that may be seen in steep bluffs. The different rounds of decorations in the tray are said to resemble in a crude way these layers of different material.

H. Akáush (sunflower tray). The name is derived from the fact that the design resembles the sunflower. 

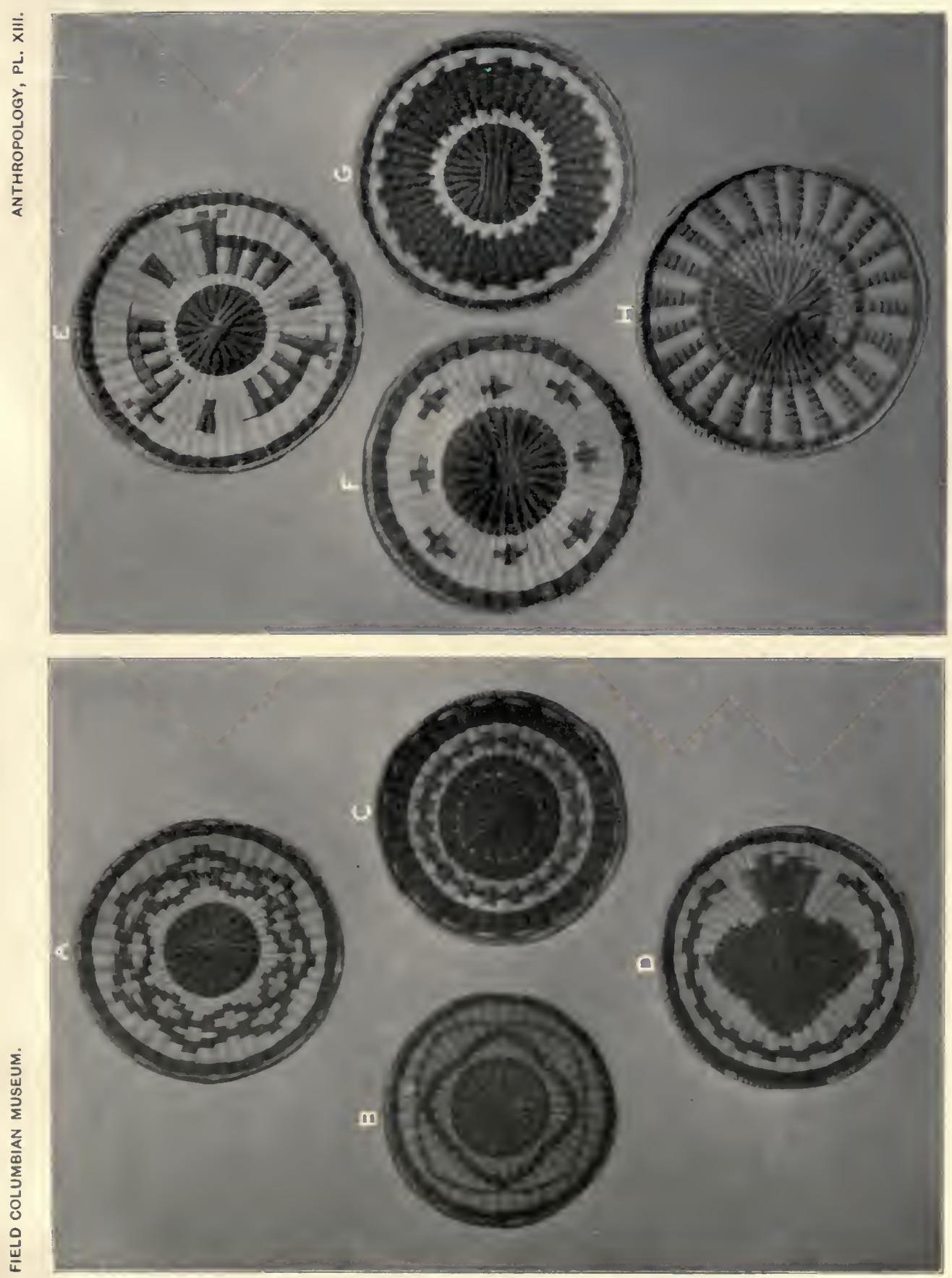


\section{THE LIBRARY \\ OF THE \\ UNIVERSITY OF ILLINOIS}


(Artemisia tridentata var. angustifolia, Gray), one of maövi (Gutterezia euthamiæ, T. \& G.), and a turkey feather, so that these báhos were dressed-as the Hópi say-in the same manner as most of the Hópi prayer-sticks.

The altar remains in the same condition as on the previous day.

Some of the women again work on their trays, at the same time practicing songs. But most of them spend the time at home, making piki for the approaching ceremony, this being the occupation of the women throughout the village on this day.

A few explanations about the Oráibi trays may be of interest. These trays, of which a number of types may be seen on Plates XII to $\mathrm{XIV}$, are now made in a great variety of sizes and designs. This seems to be due partly to the efforts of the Indian trader and others to induce the women to invent new designs. Originally, it is said, only such trays were made as the kwa (eagle), tcöb (antelope), probably the Angwúshnacomtaka (The One with the Crow feather fastened to) which is a certain Katcína, tuvip (sling), qöqơn (round about), morí (bean), oátckal (rock ledges), etc. These names apply to the designs. (See explanation in connection with PIs. XII, XIII, and XIV.) Most of these patterns are still made, such às the tūvíp, oátckal, qöqơn, nángui, poning, being the most common Ai The various Katcina designs, with the exception of perhaps the Angivushnacomtaka and Chilitocmoktaka, are late inventions.

The materials used are the following plants: cíwi (Parryella filifolia, Torr. and Gray) for the framework, or warp, of the tray, and shiwáhpi (Chrysothamnus Howardii [Parry] Greene) for the body or woof. The first is used with the bark on, the latter is decorticated while green. The latter only is dyed, a large number of sticks being dyed at one time. At present, mostly analine dyes are used, which are purchased from the traders. Formerly, the following are said to have been used chiefly: For red, the blossom of a plant called "hohóíci" (Thelesperma gracili, Gray); for yellow, the blossoms of shiwáhpi (already mentioned); for green the same, with the addition of a few black beans; for dark blue this bean only; for black the seed of tcökákavu, a species of sunflower (Helianthus annuus, Linn.). Usually, some cíöonga ("bitter salt") an alkali deposit found at nearly all springs and also at other places in 'lusayan, is added to these blossoms and seeds, when they are boiled, to give fastness to the dye. For light green, I believe sometimes also the green bark of shiwáhi is used. These native dyes are still occasionally employed, though generally only in part, in making trays.

"For explanations of these terms, etc., see "Explanations" given in connection with the different plates. 
In commencing to make a tray two sets of sticks of cíwi, two sticks taken together, are tied or wound together side by side and these two sets of three or four "double" sticks, then laid crosswise, the projecting ends slightly bent apart and the lacing of the woof sticks at once begun. (See H, Pl. XIV.) Almost invariably sticks of one color are used for the center of the tray. As soon as about an inch has been woven, other sticks or ribs are inserted into the woof at the spaces left vacant by the four sets of ribs projecting from the center (see G, Pl. XIV), and then the tender, soft sticks are run around the center, one after the other, by pushing them downward between two sticks and upward between the next two. The right hand is used for this, while an awl is kept in the left hand with which the sticks, thus taken through, are pushed and pressed closely together. (See E, Pl. XIV.) At the next round the woof is taken through downward, where at the preceding round it was passed upward, so that the ribs are covered on both sides. For every color in the design a special stick, of course, is used, which is run as far as that part of the design goes, where the stick is broken off, the end hidden on the reverse side of the tray and a stick of another color inserted. Sometimes, where the figure is small, a stick can be used over one or two ribs, or bones as the women call them, only, which makes the work very tedious. When the desired size of the tray is reached a part of the ribs are broken off, the others bent down sideways, and then wound with leaves of the yucca plant (Yucca glauca). (See F, PI. XIV.) In order to make the sticks pliable for use they are placed and kept in moist sand while working.

\section{EIGHTH DAY. TOTÓK̆A.}

As in all Hópi nine-day ceremonies, this-the eighth-day is one of the most important of the nine days. The women are up at a very early hour. As soon as they have made their morning offering (kúivato) they usually go to their homes to attend to their household duties. The men also perform the rite of kúivato and at once return to the kíva. Four women are sent with the netted gourd vessels after water, which they get in essentially the same manner as the chief priestess gets the water for the singing ceremony, as already described. The water is supposed to be gotten by the following clans:

From the north by the Píhkash (Young-Corn-Ear) clan.

From the west by the Tưwa (Sand) clan.

From the south by the Kwáhu (Eagle) clan.

From the east by the Honáni (Badger) clan. 


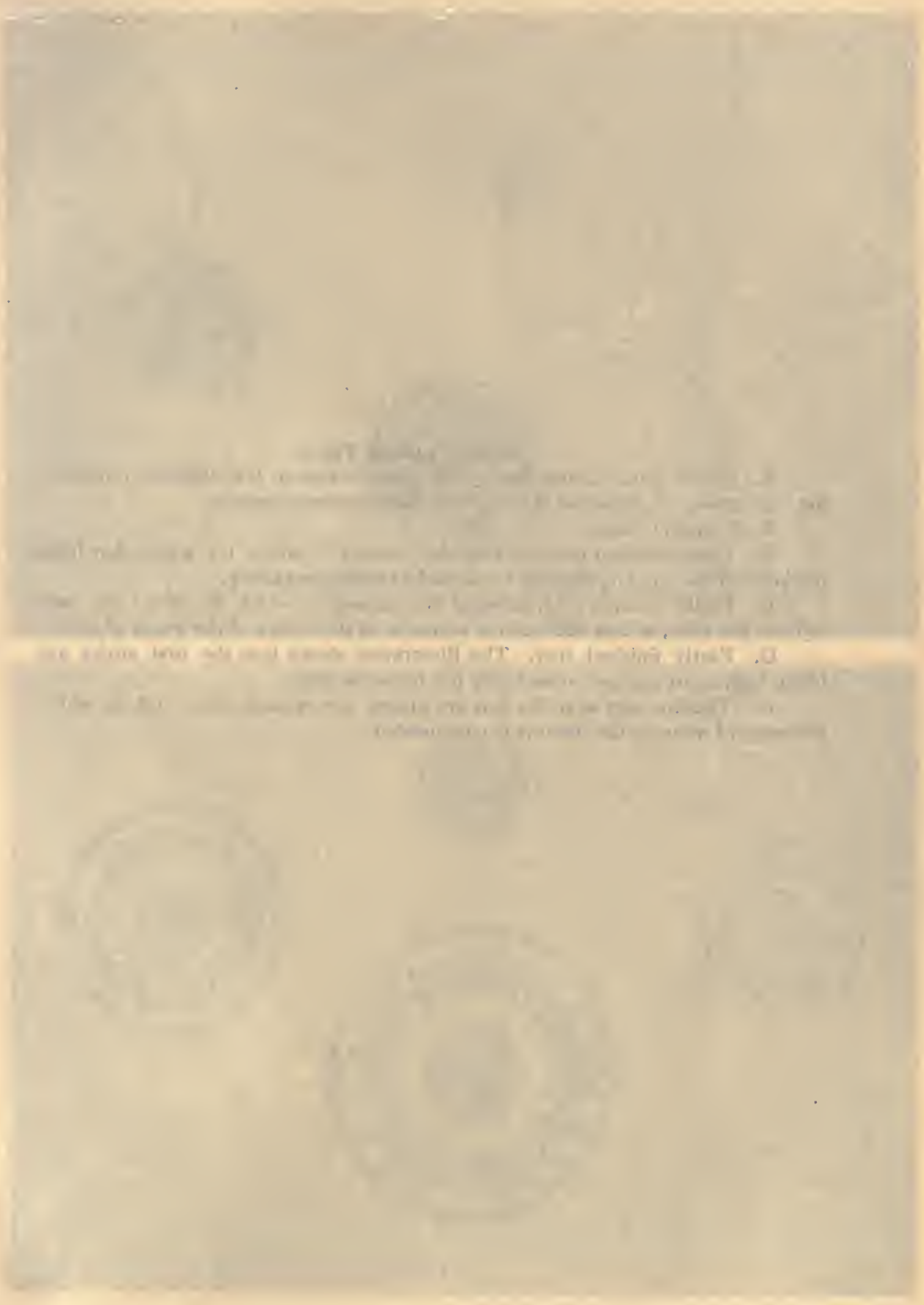




\section{PL. XIV. Various Trays.}

A. Qögö́n (round about tray). The name refers to the different circles in the decoration. It is probably one of the most common designs.

B., C., and D., Ditto.

E. Partly finished tray, showing the manner in which the sticks that form the body of the woof of the tray are added as work goes along.

F. Partly finished tray, showing the manner in which the sticks are bent to form the edge, or how the latch is wound with the leaves of the yucca plant.

G. Partly finished tray. The illustration shows how the first sticks are being bent apart and new ones being put between them.

H. The first sets of sticks that are placed across each other and on which the work of weaving the baskets is commenced. 

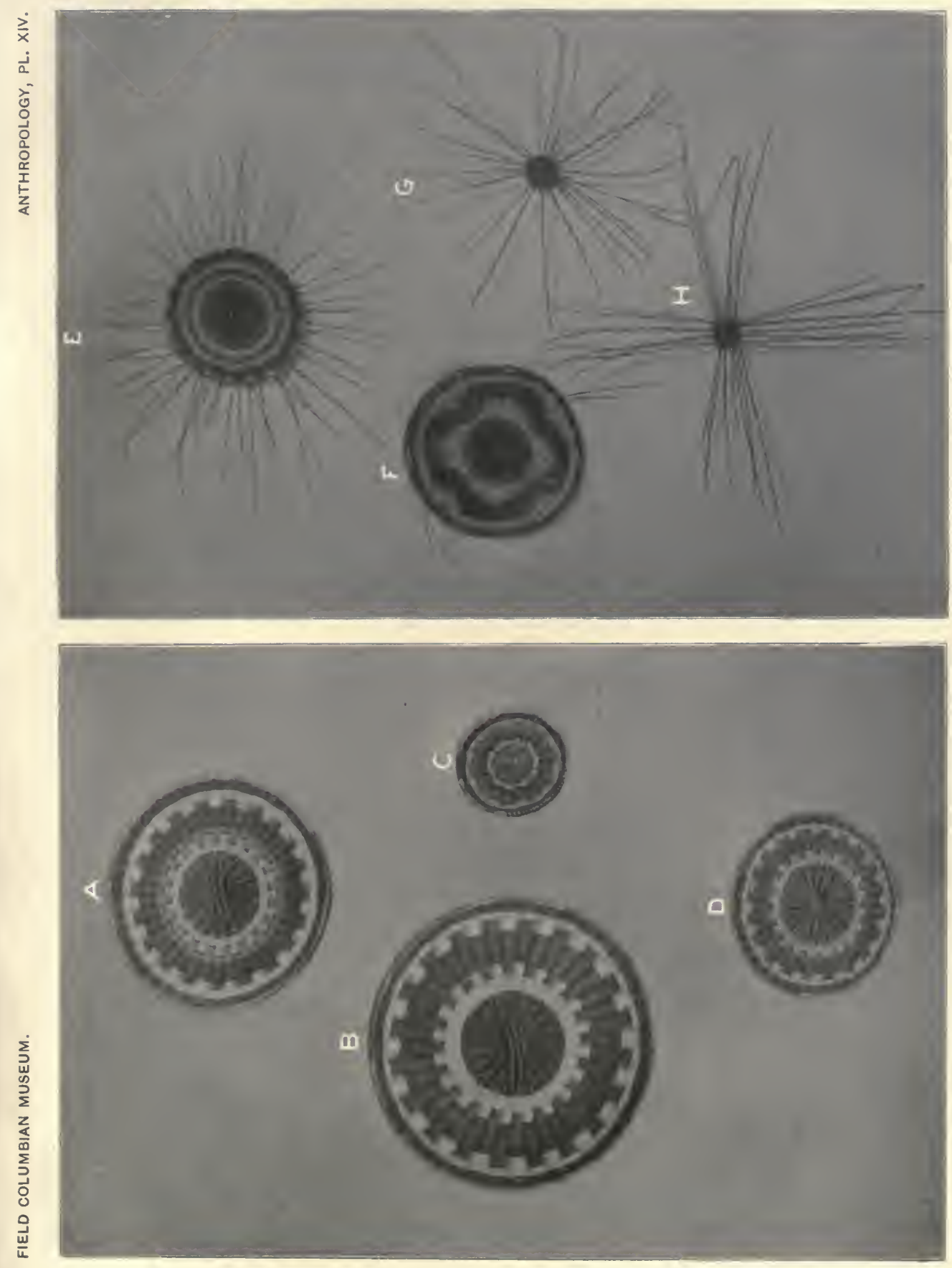


\section{THE LLBRARY \\ OF THE UNIVERSITY OF ILLINOIS}




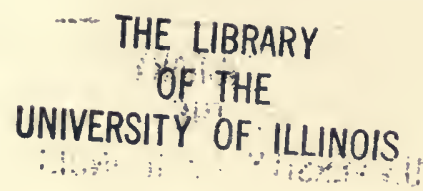



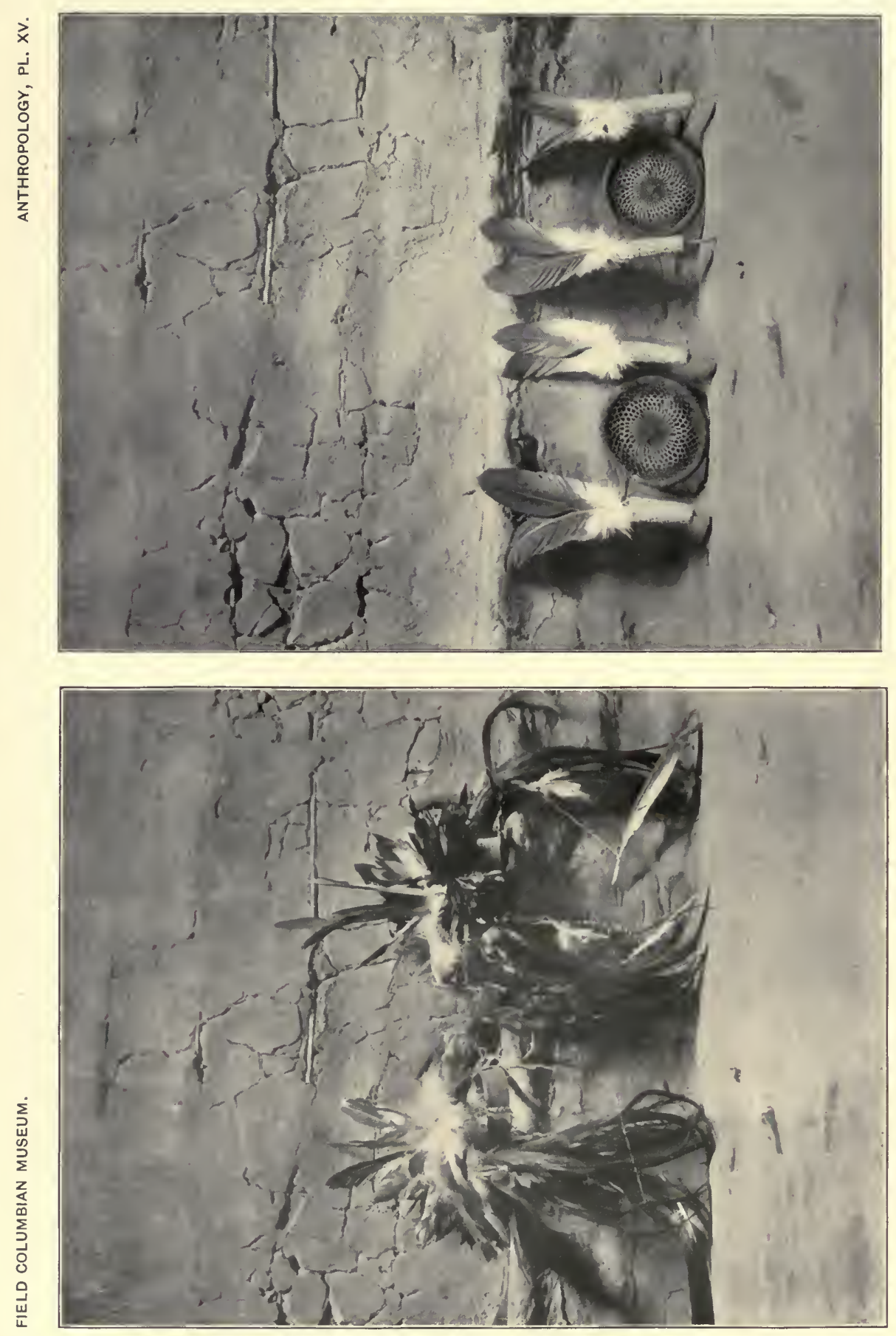


\section{Pl. XV. Various Ceremonial Objects.}

No. 1. Head-dress of the Oáqöl-mánas.

No. 2. Wheels and feather arrows used by the Oáqöl-mánas. 


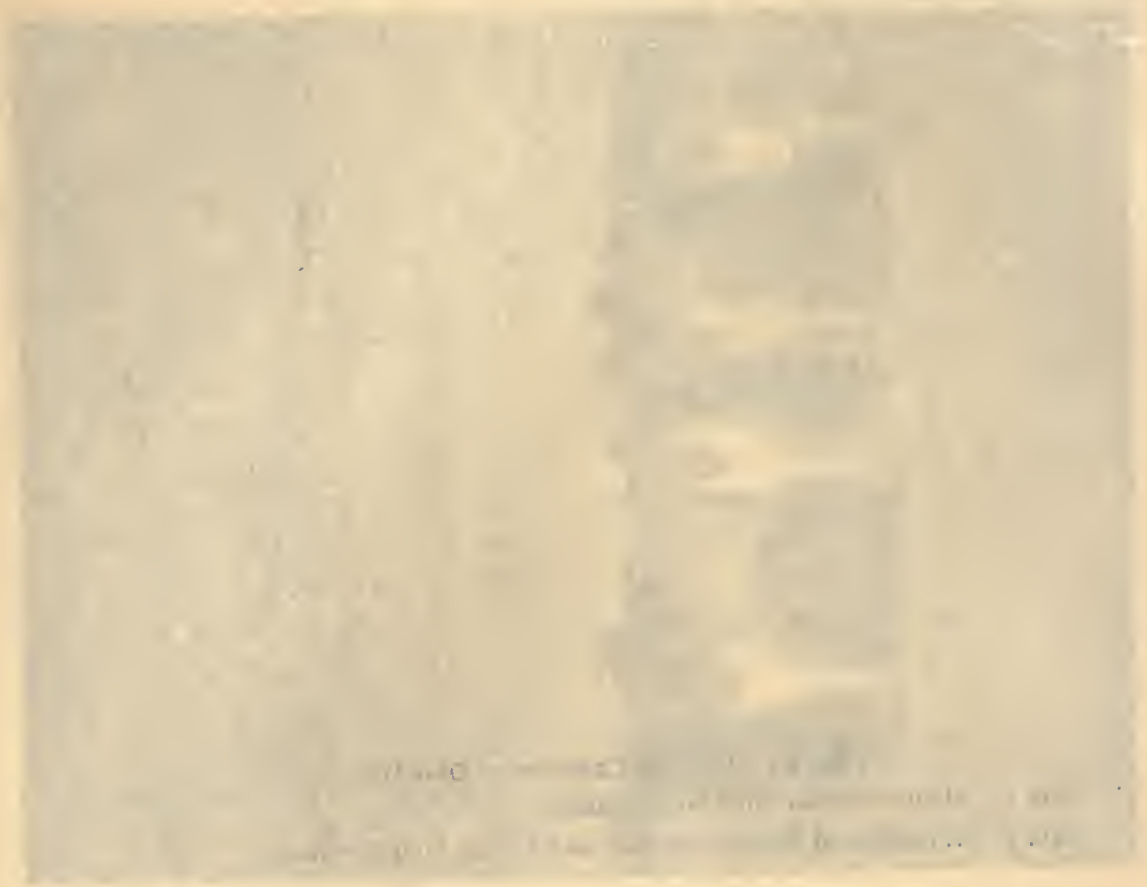


The following nakwákwosis are also prepared besides those which each water carrier takes with her: by Masátoiniwa two for the earth, one for the sun, one for the moon; by Ngósi and Hómikini each one for the earth and one for the sun.

The morning meal is taken in the kiva as usual by all participants. The two men then proceed to prepare various paraphernalia to be used in the public performance the next day. The principal objects are the two head-dresses to be used by the two Oáqöl-manas. (See I, Pl. XV.) These consist of several bands of leather or rawhide painted green, fastened together in such a manner that one band runs around and one over the head. To this is attached on the left side a horn made of the neck of a gourd, and on the right side a large blossom symbol, made of a wooden disk and small pointed slabs which are painted in various colors. Around this blossom is fastened a string of red horse-hair (táwahona). The decoration of the disk consists of eight horizontal stripes in the following colors, commencing from above: black, green, black, red, green, yellow, black, green. The pointed slabs inserted into the edge are painted red, the points green, with three black dots on each. These little slabs represent the petals of the blossoms, but at the same time represent the tail feathers of a summer bird called "wuriñawuu." From the horn are suspended several nakwákwosis of large eagle breath feathers, one large buzzard wing feather, and a string of black and white yarn twisted together, which is called sóho.

To the band that runs over the head is attached in front a bunch of yellow, red, and green feathers, supposed to be parrot feathers; farther back a bunch of short eagle feathers-the so-called "kwáchakwa," which is found on many masks and head-dresses-and finally, two fine bald eagle tail feathers which are fastened in an upright position.

Besides this head-dress two pair of moccasins, two pair of ankle bands, and two single arm bands are prepared and painted green.

The work on these objects is mostly done by Hómikini; Masátoiniwa soon proceeds to paint up two netted wheels and four feathered arrows. (See 2, Pl. XV.) The first are called "mumánpi" (shooting target), the arrows, "mðtövu." The latter consist of a corn-cob, into one end of which a pointed stick is inserted, into the other end two medium sized eagle wing feathers. Similar objects are used, especially at about this time of the year, by the children of the village for play-

${ }^{3}$ Feathers of the same bird are used on the natsi of the Soyál Fraternity. (See Pl. VI., Oráibi Soyal Ceremony by Dorsey and Voth.) Eagle tail feathers represent the sun rays on the sun symbols worn by the Hópi Flute priests in the Flute ceremony. (See Pl. CCXIX., in Oráibi Summer Snake Ceremony by Voth.) 
ing, only instead of the netted wheel they use a ring (ngöla), made of corn-husks and wound with strings, and instead of the eagle feathers in the corn-cob they use any kind of feathers, but especially chicken feathers. Very few of these domestic fowls can be found with a complete tail or undisturbed wings in the village at this time of the year.

The women engage in considerable basket-making throughout the day, as they have to provide not only those to be used by them and the novices in the dance, but also a good many to be distributed as prizes. Some of the novices assist in the manufacture of trays, being instructed by the women (See Pl. XVI). This is a very tedious work, and the women complain a great deal about sore hands and aching bones.

It should have been remarked that on several occasions Yéshiwa, the husband of the chief priestess, and another elderly man, Lötókshiwa, were in the kíva during the greater part of this day. They frequently engaged in smoking and now. and then assisted the chief priest and his assistant in their work. When the latter had finished the head-rresses, wheels, arrows, moccasins, and arm and ankle bands, these objects were hung on the altar frame on both sides. I also noticed the kaonnatsi, which had been standing at the south side of the hatchway during the first four days, standing against the sand ridge at the west end.

In the afternoon the sand before the altar, is swept up and fresh sand gotten by some member of the Sand clan. One time I noticed that two girls were sent after sand after they had been given a few nakwákwosis and corn-meal, both of which were to be deposited at the place where they were to take the sand.

On those occasions, when a race for trays is to take place the next day, the chief priestess prepares two small trays of the usual kind, on which Masátoiniwa paints on this day two green lines from rim to rim, intersecting each other in the center of the tray. He then ties four hawk feather nakwákwosis to the rim of each tray at the places where the green lines touch the edge. These trays were also' fastened to the altar frame, one to each side. Masátoiniwa furthermore makes a double green báho with a long púhu (road) attached to it, which he places near the altar for use later on.

Soon after dinner Masátoiniwa sprinkles fresh, dry sand in front of the altar after the old sand has been swept up and then renews the cloud symbol already described on a previous page. He also makes a púhu and nakwákwosi and Talásnga a púhu, which they place on the floor north of the fireplace and which are deposited near a rock south of the village early the next morning. Other women sweep the kiva and take out the refuse. 


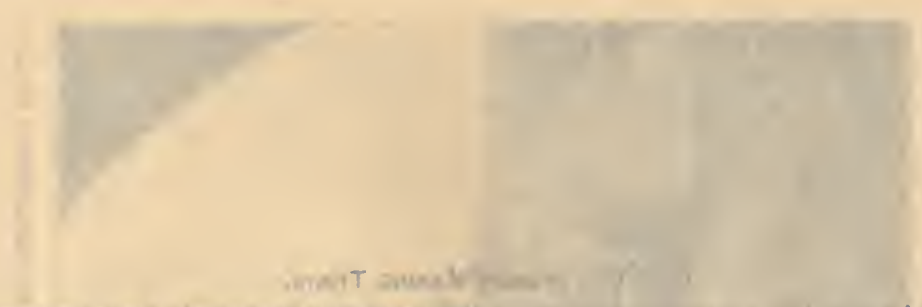

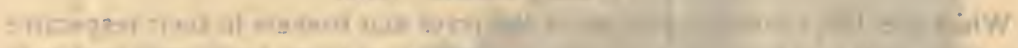

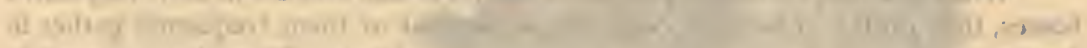

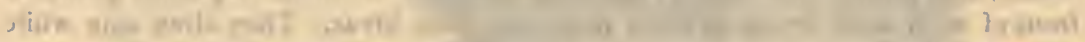

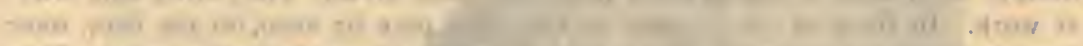
ont . .

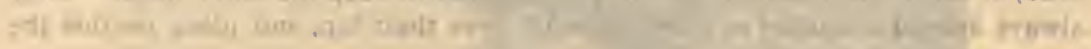

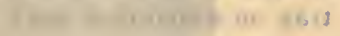




\section{PL. XVI. Women Making Trays.}

While the Hópi women often make the trays and baskets in their respective homes, they prefer to do it in company, so several of them frequently gather in front of or in some house, or even in one of their kivas. They often sing while at work. In front of the women on the plate may be seen, on the floor, some sand, in which the material used is kept in order to keep the latter moist. They always spread a blanket or other material over their lap, and place on this the tray on which they work. 


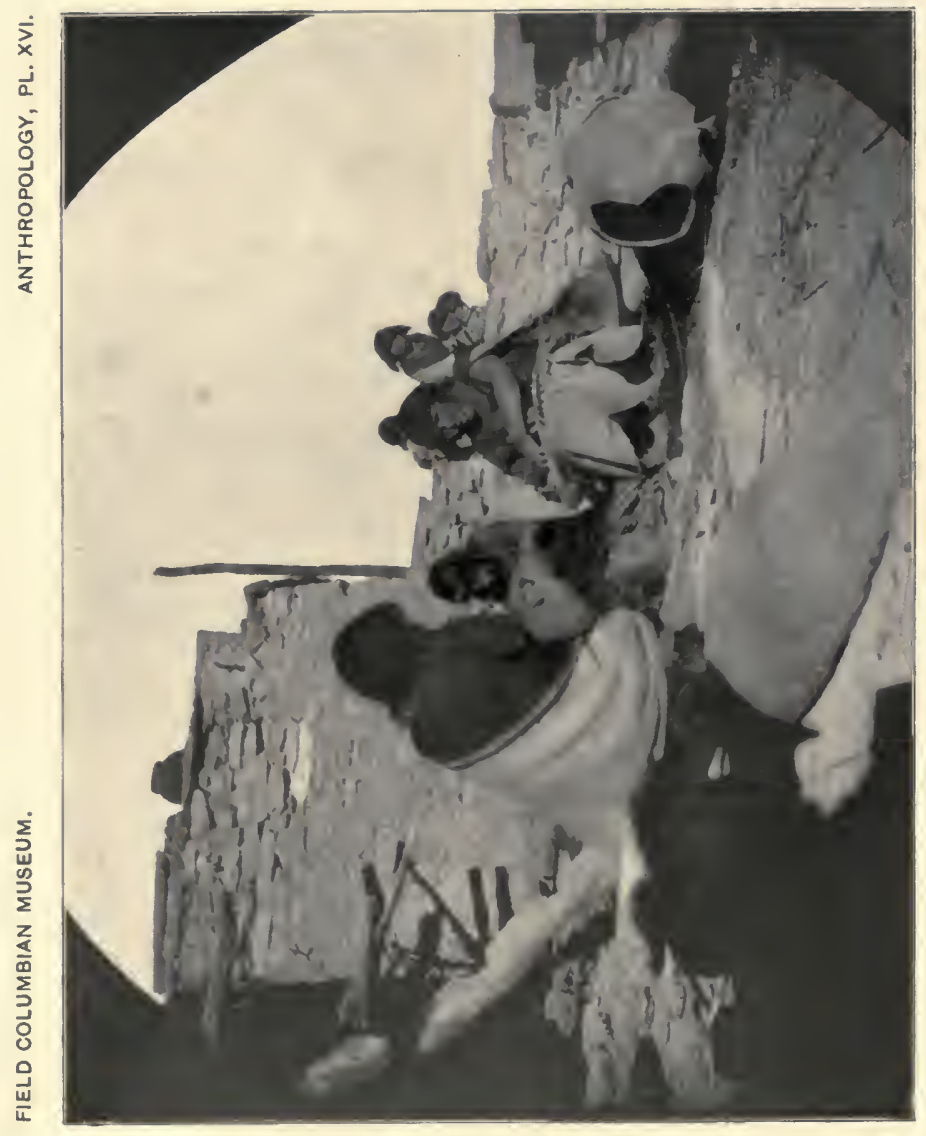


THE LIBRARY

OF THE UNIVERSITY OF ILLINOIS 
At about three o'clock Qöyángösi puts on her atðö, takes the netted gourd vessel, bone whistle, buzzard feather, meal, one púhu, and four nakwákwosis, and in her mouth a little honey and gets some water from Lánva, in the manner already described. Upon her return Masátoiniwa receives and disposes of the objects and then discharms the priestess in the same manner as described in connection with the performances on the first and fourth days (q. v.). The vessel with the water is placed near the altar with the four in which water was gotten by four women in the morning as previously noted. New participants, old and young, are assembling in the kiva at this time. In 1897 I counted in this ceremony twenty-five women, ten girls, three men, and about seven small children; in r9or, thirty-nine women, girls, and children besides the few men. Several new initiations of children and older women usually take place at this time in the manner already described. At about four o'clock the novices seat themselves on the floor along the east banquette, and the other participants arrange themselves in front of the leaders, forming a semicircle between the altar and "thể other participants. Masátoiniwa erect's the báho, he had previously made; west of and close to the típoni, stretching the string road along the floor towards the ladder. The chief priestess sprinkles a line of meal along this road $^{1}$ and to the east side of the ladder, throwing also some up the ladder, Másátoiniwa following her with a line of corn-pollen which he sprinkles on the meal line. Hereupon the same singing performance, with all the attending rites, takes place as on the first and fourth days, with the exception that during the first song the chief priestess turns down the kaobahos, laying them on their face side on the floor in front of the sand ridge. After the ceremony the men smoke at the fireplace. The women spend a short time in lively conversation, but soon most of them form in line, and slowly moving sideways along one side of the kiva around behind the altar, back on the west side of the kiva, up the elevated portion of the floor, around south of the ladder, and so on, they practice singing for the next day, accompanying the singing with the same motions of the hands-in one of which they hold their corn-ear mother -as are made with the trays the next day. This practicing is continued until the evening meal is brought in, in which all participate.

The time from the evening meal until about twelve o'clock in the night is spent in essentially the same manner as on the fourth day; singing, eating, conversation, joking, accompanied by a good deal of hilarity, comprise the program. There are usually, besides the four men, from forty to forty-five women in the kiva this night.

In Igor she made this meal line before the baho was placed in position, which, howerer, was probably due to some error. 


\section{NINTH DAY. \\ TIKKEVEE. (DANCE.)}

At about twelve o'clock in the night the practicing, and to a certain extent the loud talking, ceases, píki trays, food bowls, and watermelon rinds are taken away, parts of the kíva swept, and then all arrange themselves south of the altar, whereupon the usual singing ceremony is gone through, which ends by the rubbing of meal by Qöyángösi into the faces of all present, a short prayer by her and Masatoiniwa, and the throwing of a pinch of sacred meal to the altar by all.

The same "waving ceremony" then takes place that has been described in connection with the ceremonies of the night between the fourth and fifth day. The distribution of the objects, the assigning of places, especially to the novices, etc., was attended by a great deal of talking, instructing, and counterinstructing, as many as a dozen wornen talking at the same time, which in connection with the crying of the babies, who had been aroused from their slumber, causes one to forget for the time being that a-to the Hópis-very sacred ceremony is about to be enacted. The chief priestess again waved the típoni as in the other night. Hómikini rattled the mósilili rattle, while Masátoiniwa, strange to say, whistled with the bone whistle, which is always done by the sprinkler. The chief priestess and sprinkler then went through the same performance, east of the ladder, outside of the kiva, and then in front of the novices, as that described in connection with the night performances of the fourth day. Hereupon a short recess was taken, which was followed by more rehearsals of singing and dancing.

At about half-past three o'clock in the morning the leaders assume their usual places south of the altar and sing a few morning songs ${ }^{1}$ several times, while the women and girls take meal and go out to perform the rite of kúivato, already described.

Morning Song, chanted by the leader on the morning of the second, third, fourth, and ninth days:

$$
\begin{aligned}
& \text { Taláokuiwa, } \\
& \text { Taláokuivato, } \\
& \text { Hao! uhúm mánaha! } \\
& \text { Taláokuivato! } \\
& \text { Qöyángwunu, } \\
& \text { Sikángwunu, } \\
& \text { Taláotihā! }
\end{aligned}
$$

${ }^{3}$ Several songs are sung and they seem to vary somewhat. As they are usually sung or hummed very quietly, I have been unable to record them, but Masatoiniwa and Hómikini claim that the two given in the text are usually among those that are chanted. 
The second stanza is exactly the same, only in the third line they sing "totímhoyam" (little boys), instead of mánaha (girls).

\section{Translation.}

The day has risen, Go I (to) behold the dawn, Hao! you maidens!

Go behold the dawn!

The White rising!

The Yellow rising!

It has become light.

Morning Song, chanted by Masátoiniwa, Ngósi, and sometimes one or two others on the morning of the second, third, fourth, and ninth days:

Taláokuiwa!

Taláokuiwa!

Núhui aokúhuwaqöhö

Múyingw móngwitui,

Homítuilāoniyumuy,

'Tátötöhokahay

Möhớcivalıakwatūhui,

Wūhūpat kahaötaha

Töhökiyūyũywui

Sikvatungnawatahai.
The day has risen!

The day has risen!

Go I to behold it.

The Múyingwa chiefs

With shelled corn busy themselves.

$\mathrm{He}$ is croaking

'The water frog,

(About) big corn-ears

It is humining.

Yellow (rest obscure).

As soon as the women have all returned Masátoiniwa, Ngơsi, and usually one other woman, put on heavy blankets and their moccasins, as the night is cold, and then leave the kíva. Masátoiniwa takes a pointed stick and the báho with the long "road" from the altar, Ngôsi one of the crooks, the third woman also a crook and a corn-ear, and all take also some sacred meal. Following the trail that leads from the village in a south-easterly direction, they descend the mesa and proceed on the main trail leading towards the east for about a quarter. of a mile. Here they turn to their left and stop about twelve or fifteen yards north from the trail, where Masátoiniwa digs a hole about a foot and a half deep, and from this in an easterly direction a trench a few inches deep. All then throw their meal into the hole and along the trench, whereupon Ngðsi places the báho into the hole and the road along the trench and Masátoiniwa closes it up. All three then take a position at the east end of the trench and facing the east they sing the following little song twice:

"Qöyángwunu kuivá.

Sikángwunu kuivá.

Put nu tálaongwayatni.",
The white dawn has risen. The yellow dawn has risen. That I shall "light embrace." 
While they.sing the last line they make a grasping motion with the right hand, in which the women hold the crook, and back towards them again as if gathering in something. They then turn their faces towards the west and sing, making the same motion at the last line:

"Sipápuni kuivá.

Sipápuni kuivá.

Put nu tálaongwayatni."
The sipapu has risen (loomed up).'

The sipapu has risen (loomed up). That I shall "light embrace." 2

Turning again to the east they repeat the first song in the same manner.

They then return to the village. Having ascended the mesa they stop just at the edge of it and sing the same songs in exactly the same manner, and then return to the kíva. Masátoiniwa said that this was an offering and a prayer to the morning star and to the sun.

During this time water and yucca roots have been brought into the kiva; the roots are mashed with stones on the floor and foaming suds are prepared in all the bowls, whereupon a general washing of the heads commences. This is considered a religious head washing to which all are subjected, even the small children. Masátoiniwa, I noticed on one occasion, was washed by his wife, while Ngósi washed herself. Those who have been initiated during the ceremony are washed by their fostermothers.

The chief priestess at about this time takes out the nátsi and places it outside of the kiva at the south end of the hatchway. Those who have made nakwákwosis for the fire the previous evening now take them out with a live ember and a little sacred meal and deposit them a few yards from the kiva towards the east.

Soon after sunrise Lománkwa, one of the village criers, who announces ceremonies, or performances connected with them, cries out that a race is about to take place and calls for volunteers to participate in the race.

In the kíva Masátoiniwa makes one púhu and four nakwákwosis, which are taken by the chief priest, or sometimes by his assistant, Hómikini, to the spring Lánva, west of the mesa, where he deposits the four nakwákwosis. With the puthu he proceeds to the rock called "Íshmowala" (Coyote-Rock-Gap), which is located a short distance south from the spring, where he deposits the puhu. The would-be participants in the mean while gather at the same place. Having

'The sipapu is the traditional opening in the earth through which the Hópi claim to have emerged from the under world. The meaning of the song is obscure. What is really meant by the "sipapu looming up," and in what way the expression "embrace or inhale its light" is to be explained, nobody thus far could tell. It is highly probable that this is a remnant or a corrupted form of an old song.

${ }^{2}$ I. e., its light I shall embrace or inhale. 


\section{THE LIBRARY}

OF THE
UNIVERSITY OF ILLINOIS 


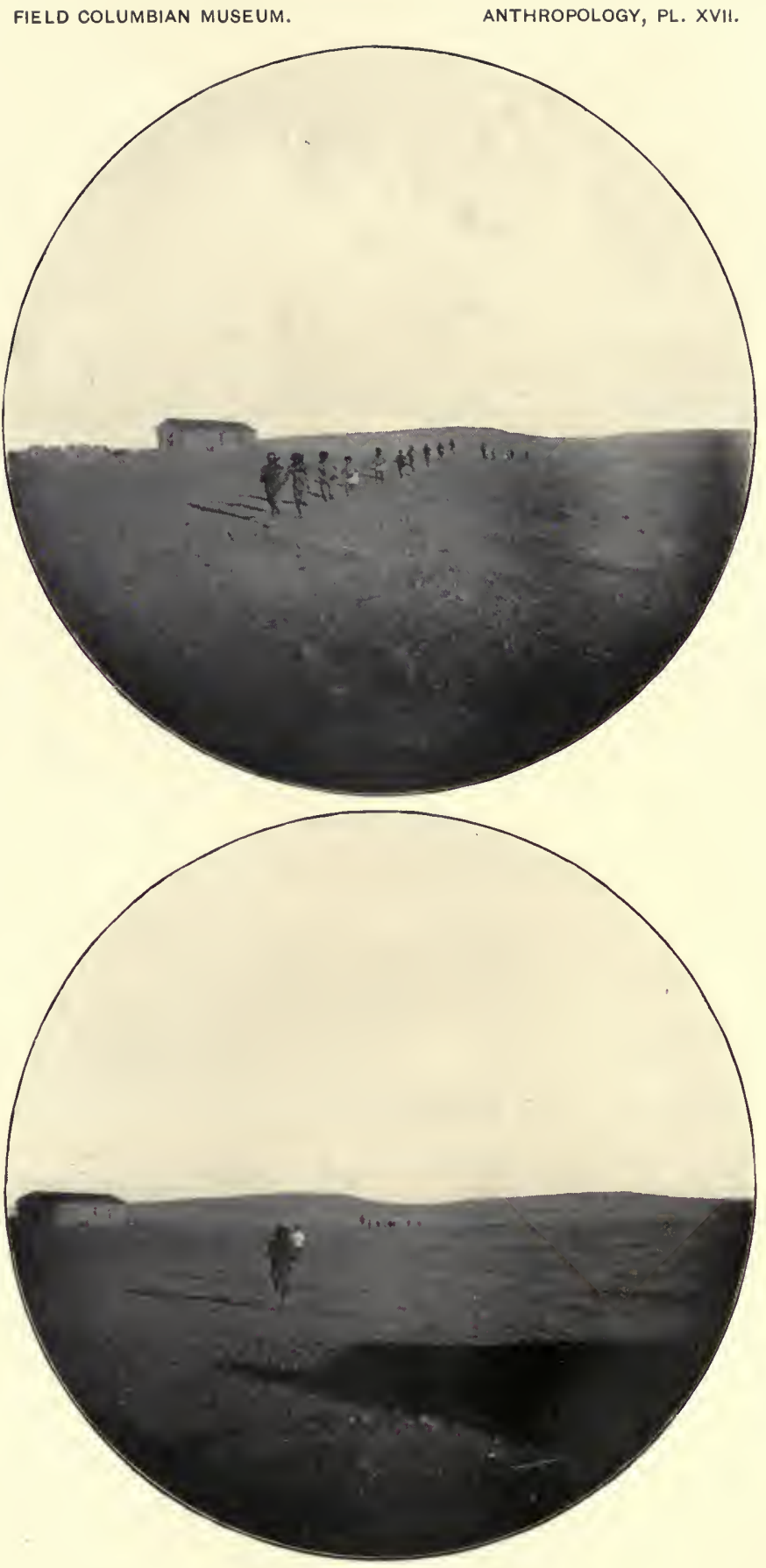




\section{PL. XVII. A HópI RACE.}

Races take place in connection with various ceremonies in the spring months, but many take place irrespective of any ceremonies. Usually the different kivas contend with each other in these last named races. The racers on these occasions sometimes run from three to eight miles. 

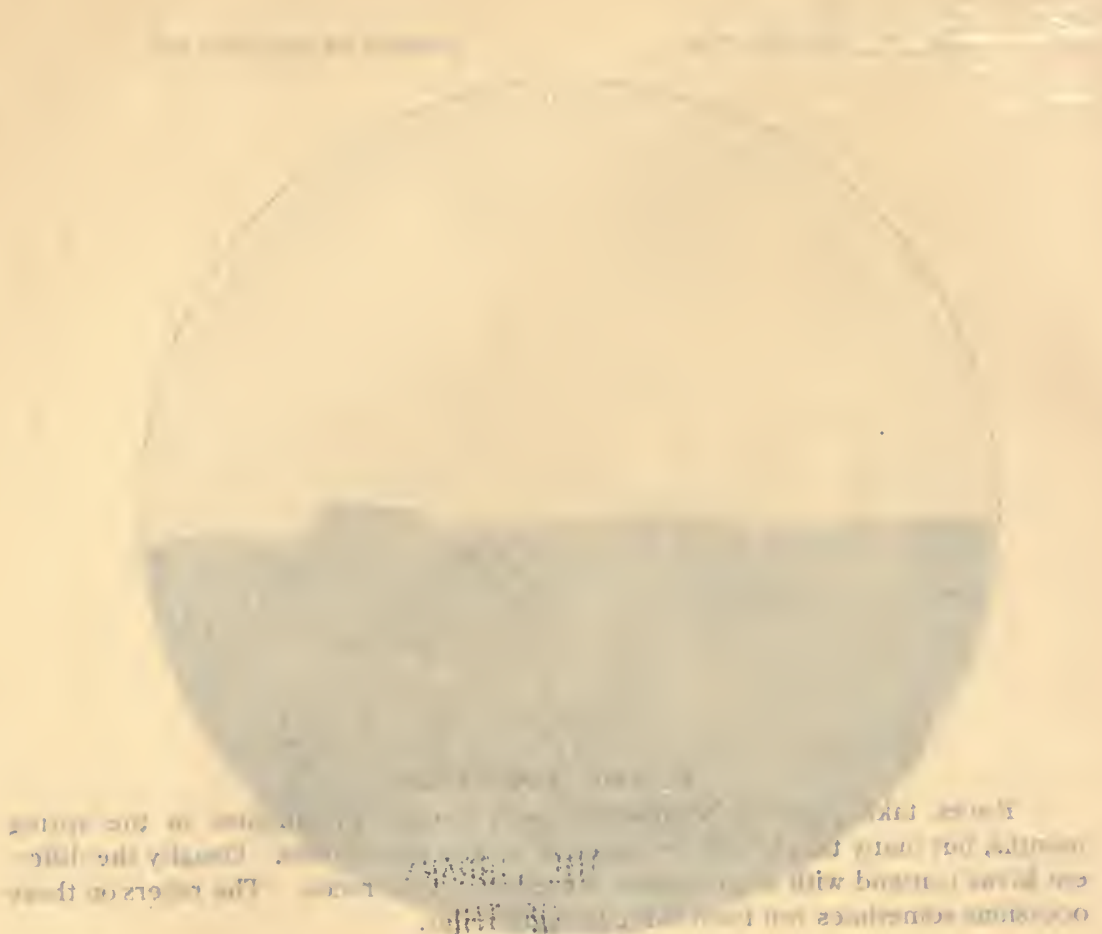

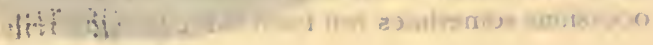
$\therefore 1 . \quad \therefore \quad \because i \cdots+3$ 
THE LIBRAKY

OF THE

UNIVERSITY OF ILLINOIS 


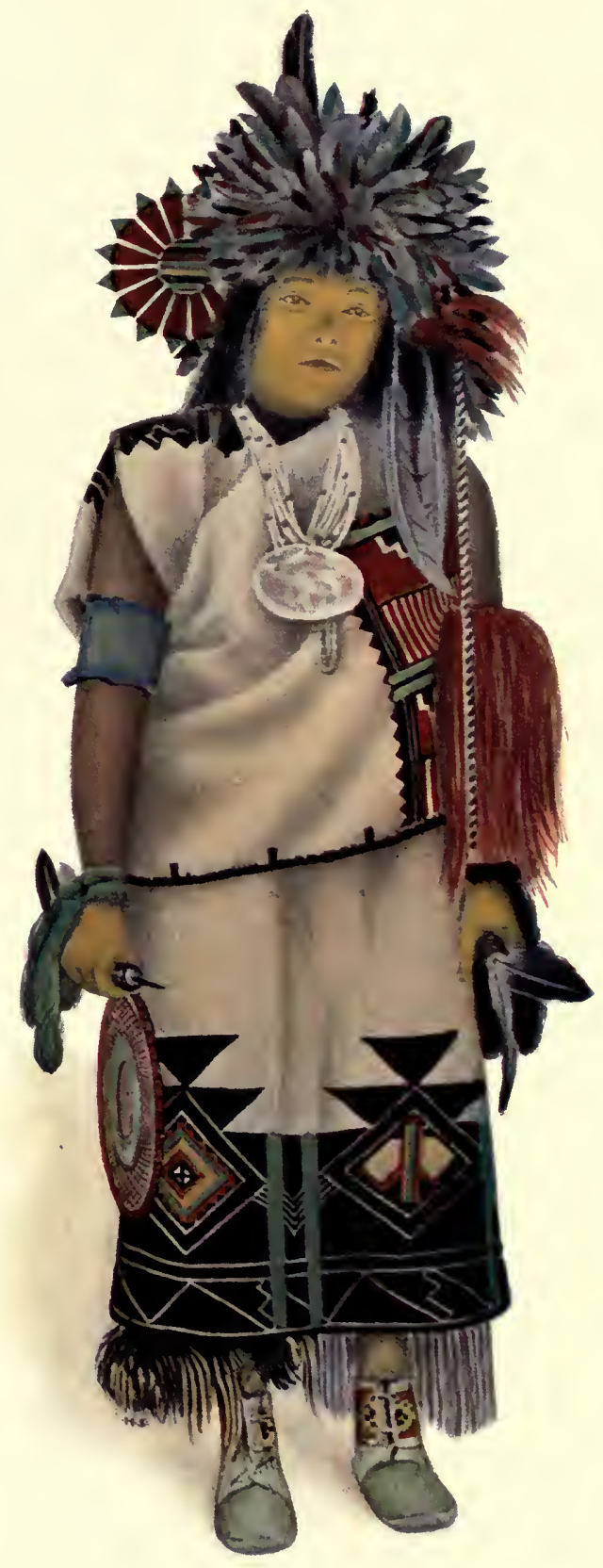




\section{PL. XVIII. AN OÁQÖL-MÁNA.}

The plate shows the Oáqöl maiden as she stands in the sourheastern part of the deeper portion of the kiva, ready to follow the dancers to the plaza. She holds in her right hand a netted wheel, and one of the feather arrows; in her left hand the other of the arrows. The plate was prepared from a life-size figure as it stands in the case which contains the Oáqöl altar in the Field Columbian museum. The artist has succeeded in making a very accurate representation of this personage. 

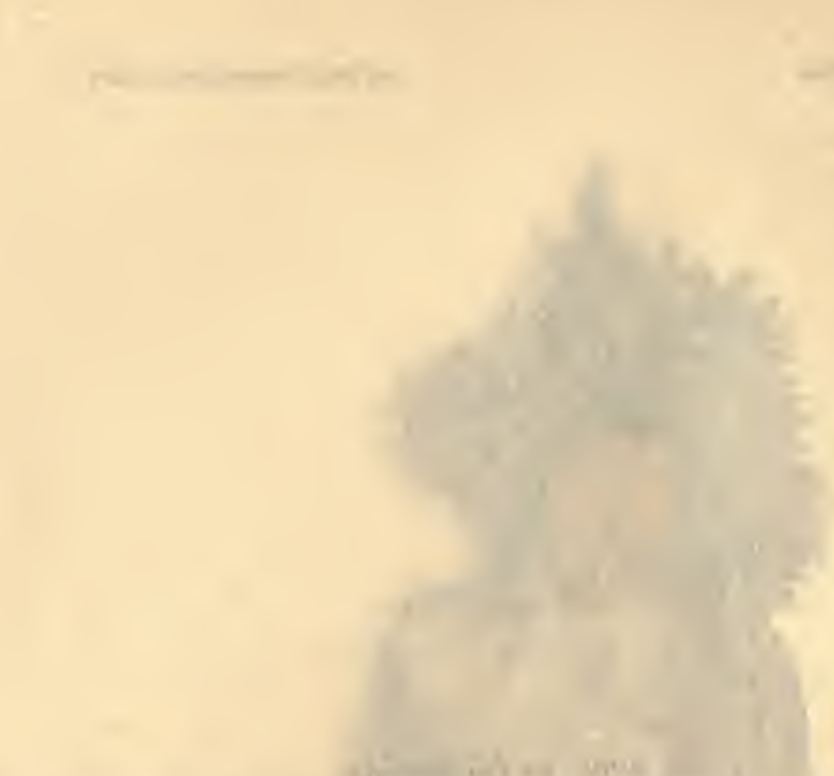

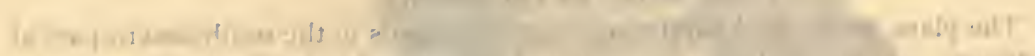

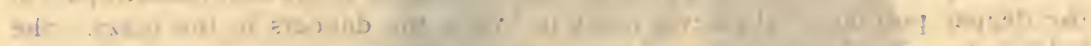

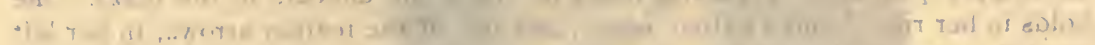
ex +1 in ip.

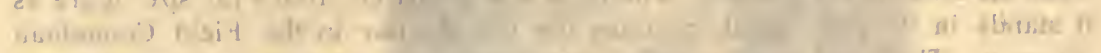

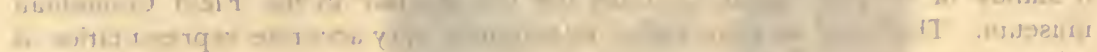

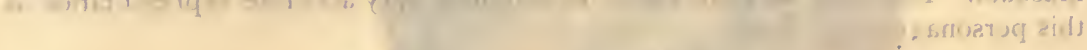


deposited the prayer-offering, Hómikini addresses the racers in the following words :

"Pai ítam háhlaikahkang, öokáokahkang yáhtukni. Níkang mómik yámakat átsvi pas pai íta mongwáctotini. Pai pi okiwá! Pai yánhakam ita tủnátyaokahkango; púu ímui itánamui kíyamui yaíwawicni ; kíyamui yúngwicni. 'Pai háhlaikahkango!"

"Now we happily, courageously, shall race. But on account of (owing to) the one being ahead, we must (surely shall) terminate this. (Well) now alas! Now thus we are concerned about (this). Now these (referring to the racers) to our fathers' houses (referring to the chiefs) shall ascend; the village they shall (will) enter. Now gladly!"

Having said this he runs, on to a rock called "Hurú-oa" (HardRock), which is situated still farther south. Having arrived here he raises, lowers, and again raises his hands, which is the signal for the racers to start. The first one to arrive at this place receives as a prize the smaller of the trays, both of which have in the mean while been placed against a little shrine on the plaza, in the village by Ngôsi.

Those racers who intended to compete for the smaller, tray only, return to the village from here, ${ }^{1}$ the others continue to run, first southward, then they round the mesa.point, turning towards the east, and as they keep turning to the left, they finally ascend the mesa from the east. (See Pl. XVII.) The winner dashes to the plaza and takes his tray. The nakwatkwosis that are tied to the rims of the trays, I am told, the winners deposit in their fields, the trays they keep as mementos of the race, but they are used in the house and sometimes even sold.

In the kiva they have, in the mean while, commenced to array the two Oáqöl-manas (Oáqöl maidens) as follows (See Pl. XVIII):

Their costume consists of the following articles: a large embroidered, ceremonial robe (túi-hi) which is formed into a dress; a men's ceremonial kilt (pitkuna), which is taken around the upper part of the body under the right arm, the two. ends. being tied together by two corners over the left shoulder. The robe is held in place by a wokókwāwa ("big belt") a white, cotton belt with long, knotted fringes, which is taken around the waist and tied on the left side and to which an old bell is attached, of which several had been standing behind the altar for several days. ${ }^{2}$ Costly turquoise beads are tied to their ears and many strands of beads, from which are suspended several abalone

I am told, however, that the winner usually continues in the race. All along the line some participants generally drop out of the race and return to the village.

${ }^{2}$ These bells are held sacred by the Hópi. There is noquestion about them being old, and the Hópi frankly state that some of them have been banded down to them from the time when the Spanish missions were still in existence among them. On one of the bells I found the following inscription: "Sic nomen Domini benedictum." 
shells, are hung around their necks. On their feet they wear the moccasins and ankle bands that were prepared the previous day. Skeins of black and green yarn are tied around the wrists and a string of red horsehair (táwahona) around the left upper arm under the green leather arm band. Before they are entirely dressed their faces are decorated with a yellow powder prepared from the petals of sunflowers. First, water is spurted into their faces-usually by Hómikini-and then the powder applied to the wet skin. Their hands are also painted yellow and a ring is made above the wrists with the same material. All the' other women only place around their shoulders an atőö (small ceremonial robe).

When the Oáqöl-manas have been dressed and painted up, Ngósi and three other women each take one of the netted gourd vessels from the altar, a buzzard feather, and a bone whistle, all the others taking their trays, and all file out of the kiva, the chief priest sprinkling them from the medicine bowl before they ascend the ladder. On those occasions where trays have been made for the race, the chief priestess takes them along and places them against the shrine on the plaza. ${ }^{1}$ Having emerged from the kíva she also takes the corn-ear, eagle feathers, and sprig of cúvi from the nátsi pedestal, and then heading the line, leads the women to the plaza. (See No. I, Pls. XIX and XX.)

In the kíva the two Oáqöl-manas have in the mean while taken up the wheels and feathered arrows from the altar. Standing south of the altar they roll the wheel towards the south-west corner on the floor and shoot the arrow at it, whereupon they take a stand in that portion of the kiva, one behind the other and each one holding in one hand one of the wheels in the other an arrow.

During this time the chief priest has picked a bundle of trays, tied up in a blanket, the medicine bowl, and aspergill, and after having asperged the two mánas, he proceeds to the plaza, where he arrives when the women have formed the dance circle. Having placed the bundle of trays on the ground in the center of the circle (see P1. XXI), he goes along the line of the dancers and asperges them, whereupon he returns to the kiva, leaving the bundle where he has placed it. The women all bend slightly forward and begin to sing, moving at the same time slowly from right to left and waving the trays, which they hold with both hands, concave side forward, to the time of the singing. (See P1. XXI.). As soon as the dancing has started the two Oáqöl-manas appear on the scene, rolling the wheels along the ground, shooting the arrows at them, picking both up, shooting them again, etc., while coming to the plaza. (See Pl. XXI.) Here they con-

${ }^{1}$ Others claim that this is not necessarily done at the first dance, but sometimes late in the forenoon. 

PL. XIX.

No. I. The women going from the kíva to the dance plaza, each one being arrayed in her ceremonial robe, and carrying a tray which is waved up and down, and from side to side, during the dance.

No. 2. Masátoiniwa, the chief priest, returning to the kíva from the plaza, holding in his left hand the medicine bowl and asperger with which he has asperged the dancers on the plaza. 
FIELD COLUMBIAN MUSEUM.

ANTHROPOLOGY, PL. XIX.

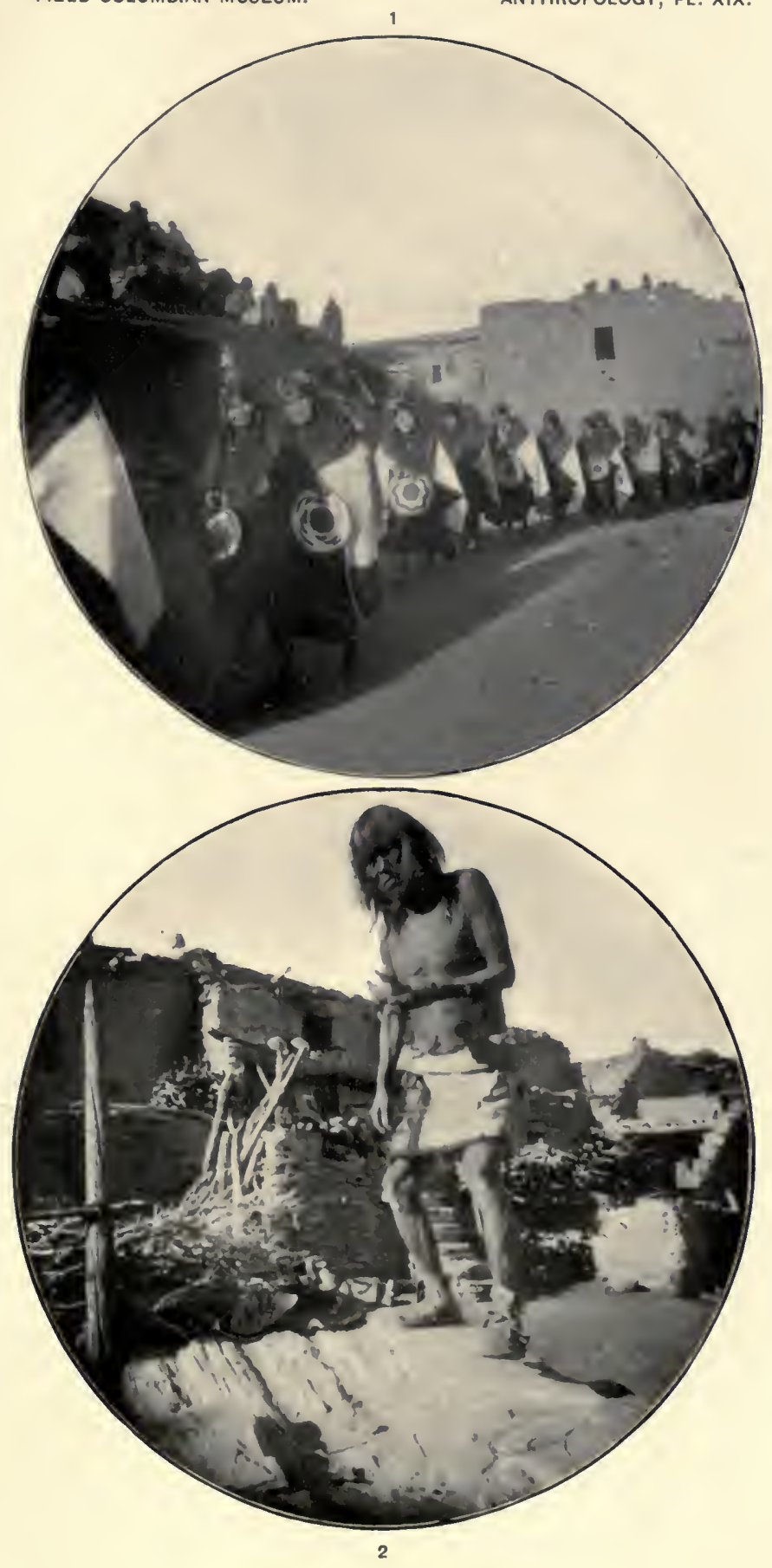




\section{THE LIBRARY \\ OF THE \\ UNIVERSITY OF ILLINOIS}



Pl. XX. ó́qöl-mánas Proceeding to the Plaza.

The plate shows the Oáqöl maidens as they leave the kíva and start for the plaza. On one of the illustrations the assistant chief is seen repairing something on one of the moccasins of a mána. The other illustration shows children following the maidens, a very common sight whenever men and women, dressed in ceremonial costume, appear in the village. 


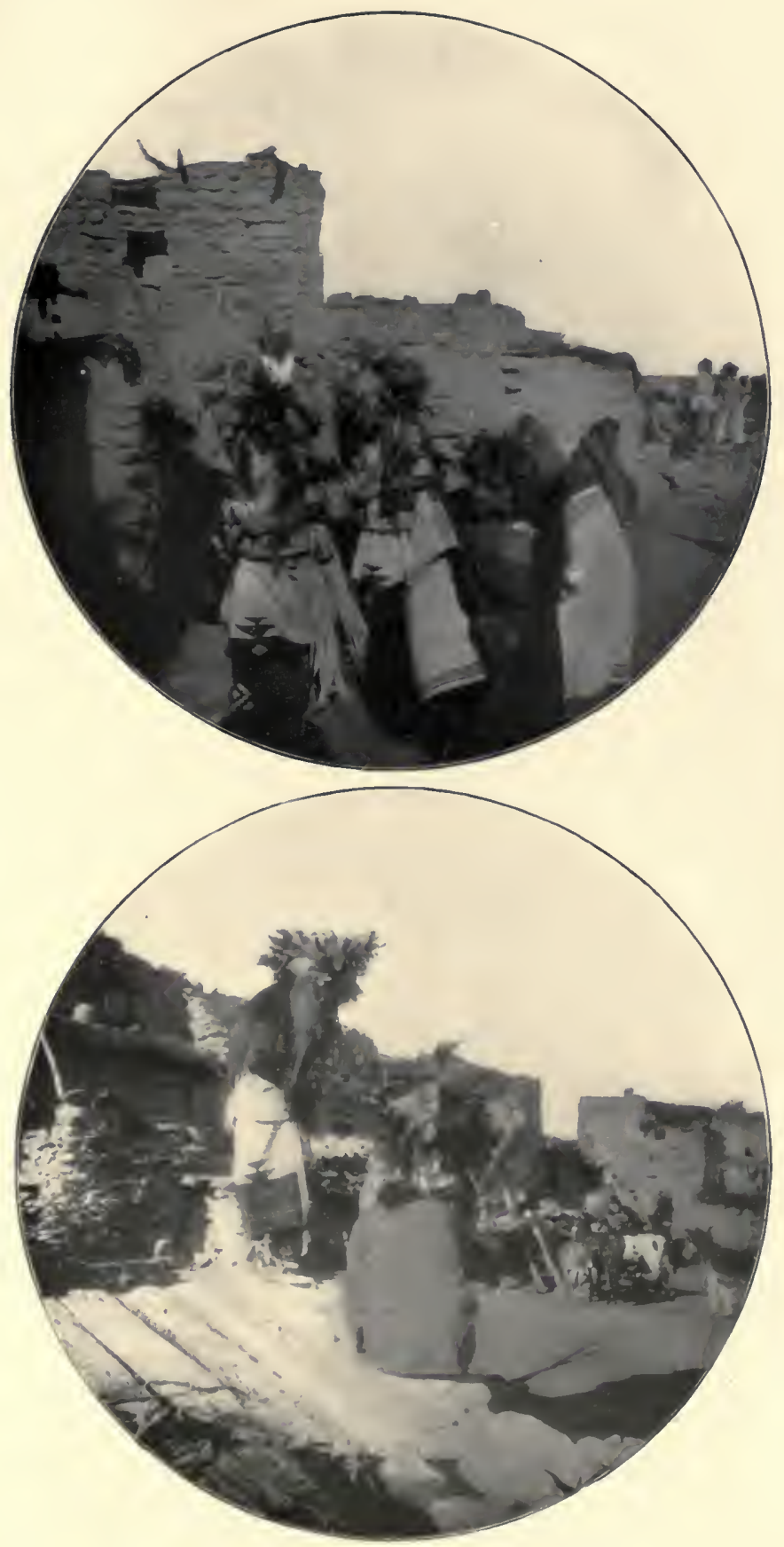


THE LIBRARY

OF THE.

UNIVERSITY OF LLLINOI 


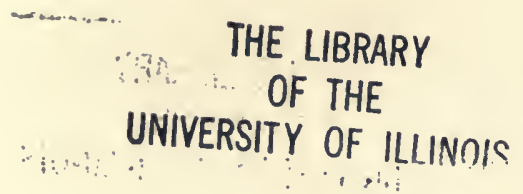




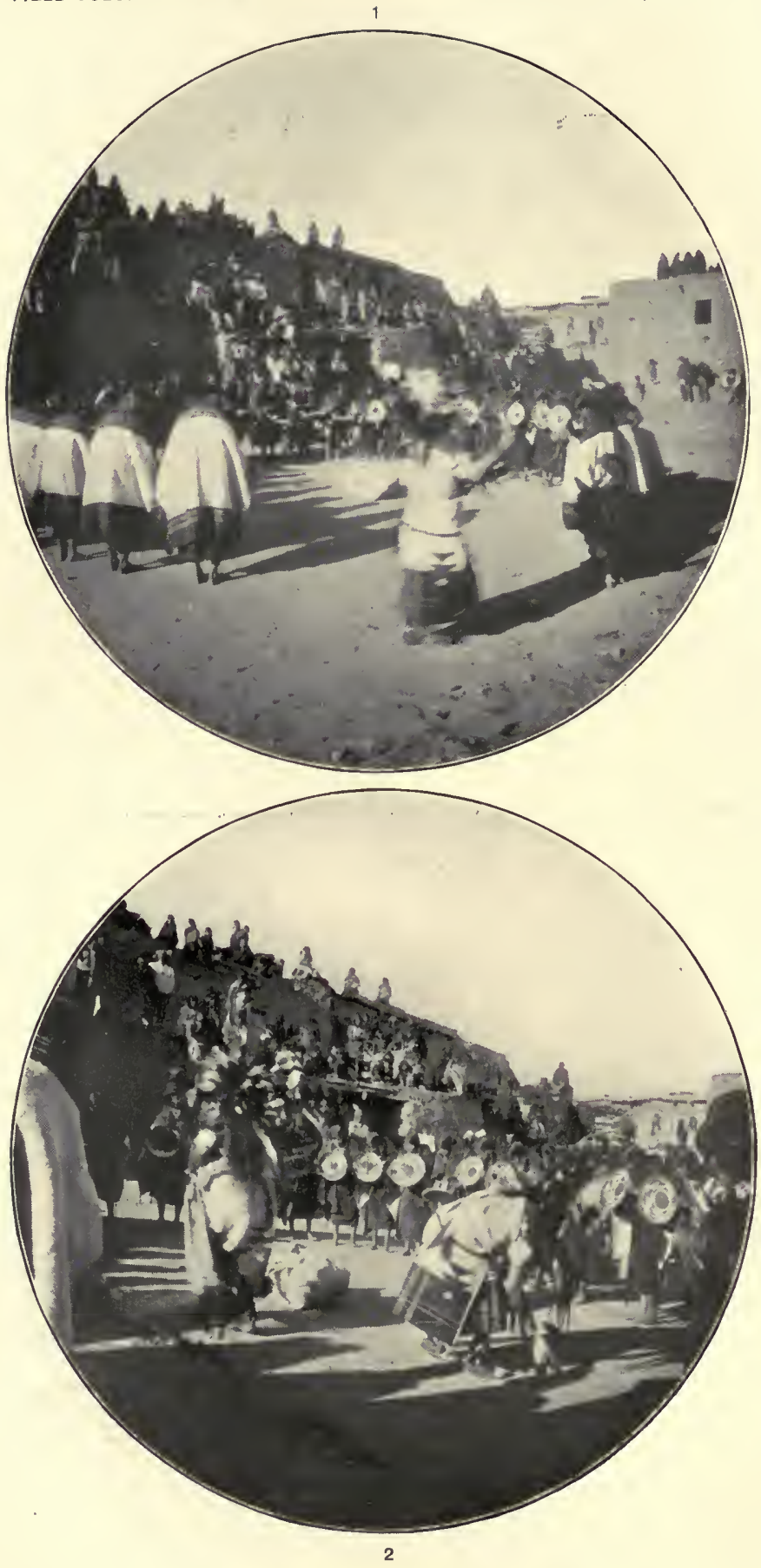




\section{Pl. XXI. The Dance.}

No. I. The plate shows the circle of dancers, and in front one of the Oáqölmanas in the act of throwing the feathered arrow to the netted wheel.

No. 2. The Dance in Progress. In front are shown the two Oáqöl-mánas, the one in the act of rolling one of the netted wheels along the ground.

In both may be seen, in the center of the circle, the bundle containing the prizes, which consist mostly of trays. These are thrown by the Oáqöl-mánas into the crowd of spectators, each one of the latter being very eager to obtain one of these prizes. 


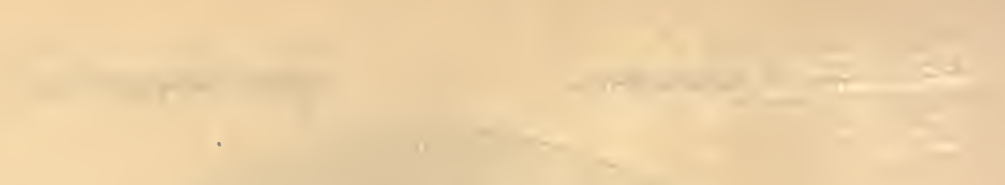

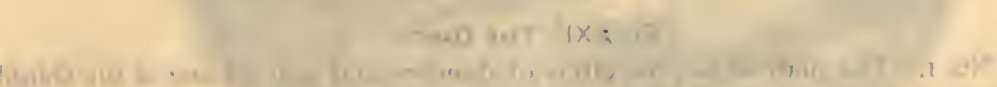

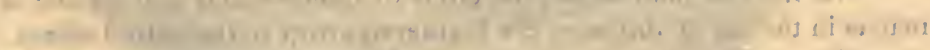

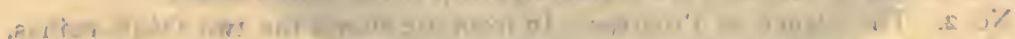

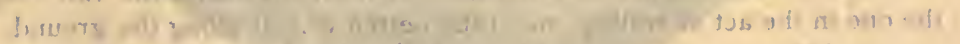

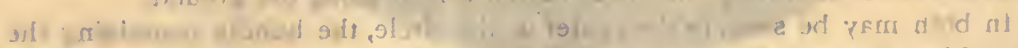

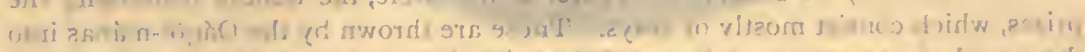

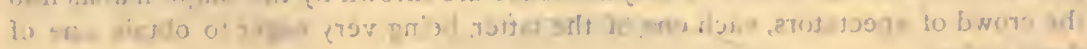
2xकी 4 : 2 - 


\section{THE LIBRARY}

OF THE

UNIVERSITY OF ILLINOIS 


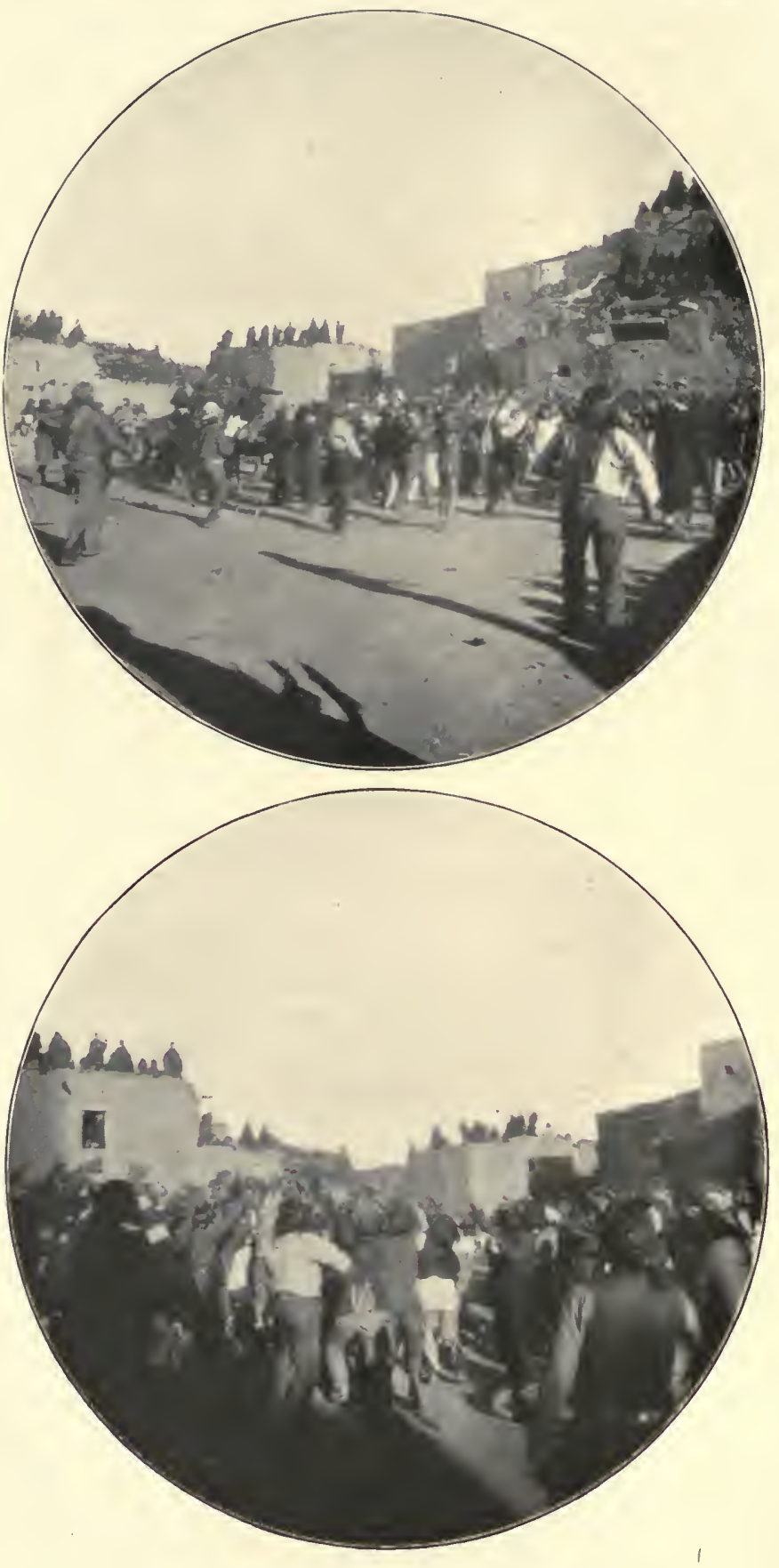


PL. XXII. Waiting for the Prize to Descend.

Both plates show the expectant crowd looking upward to the tray that has been thrown into the air by the Oáqül-mánas. Many extend their hands upward, eager and ready to snatch the prize as soon as it descends. 

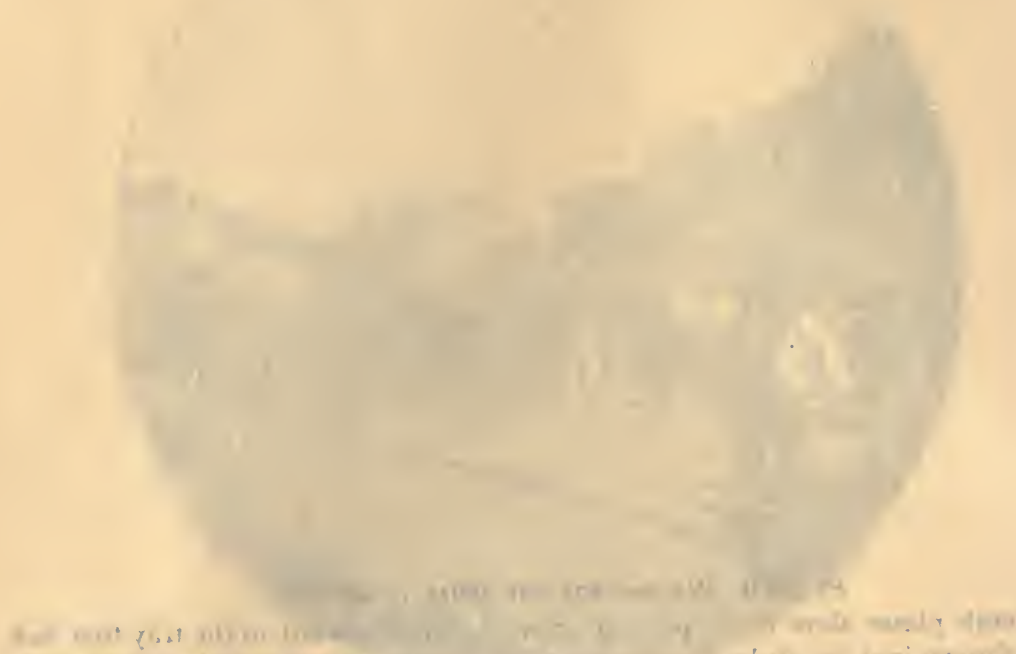

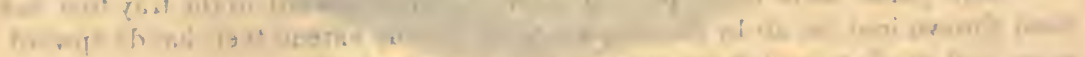
doc,

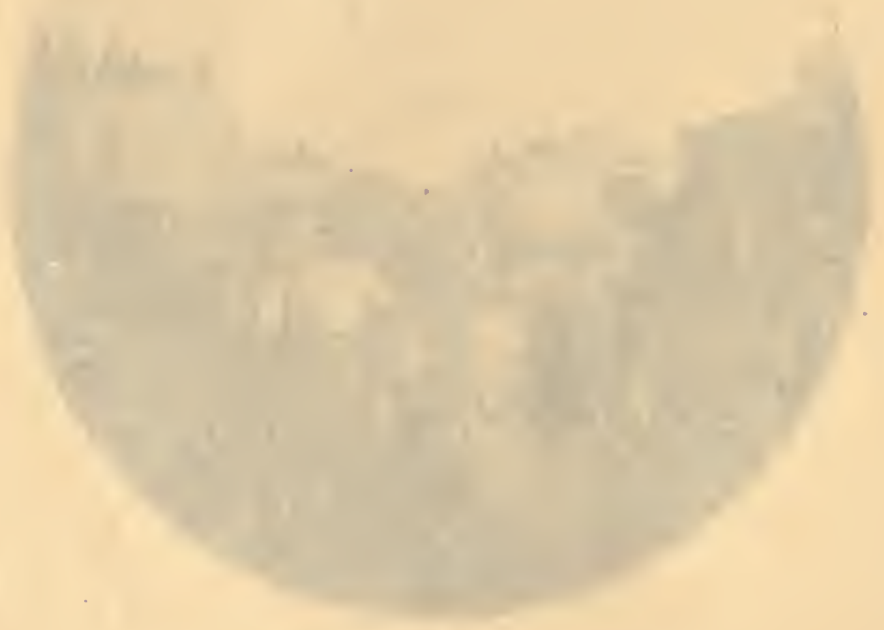




\section{THE LIBRARY \\ OF THE \\ UNIVERSITY OF ILIINOIS}




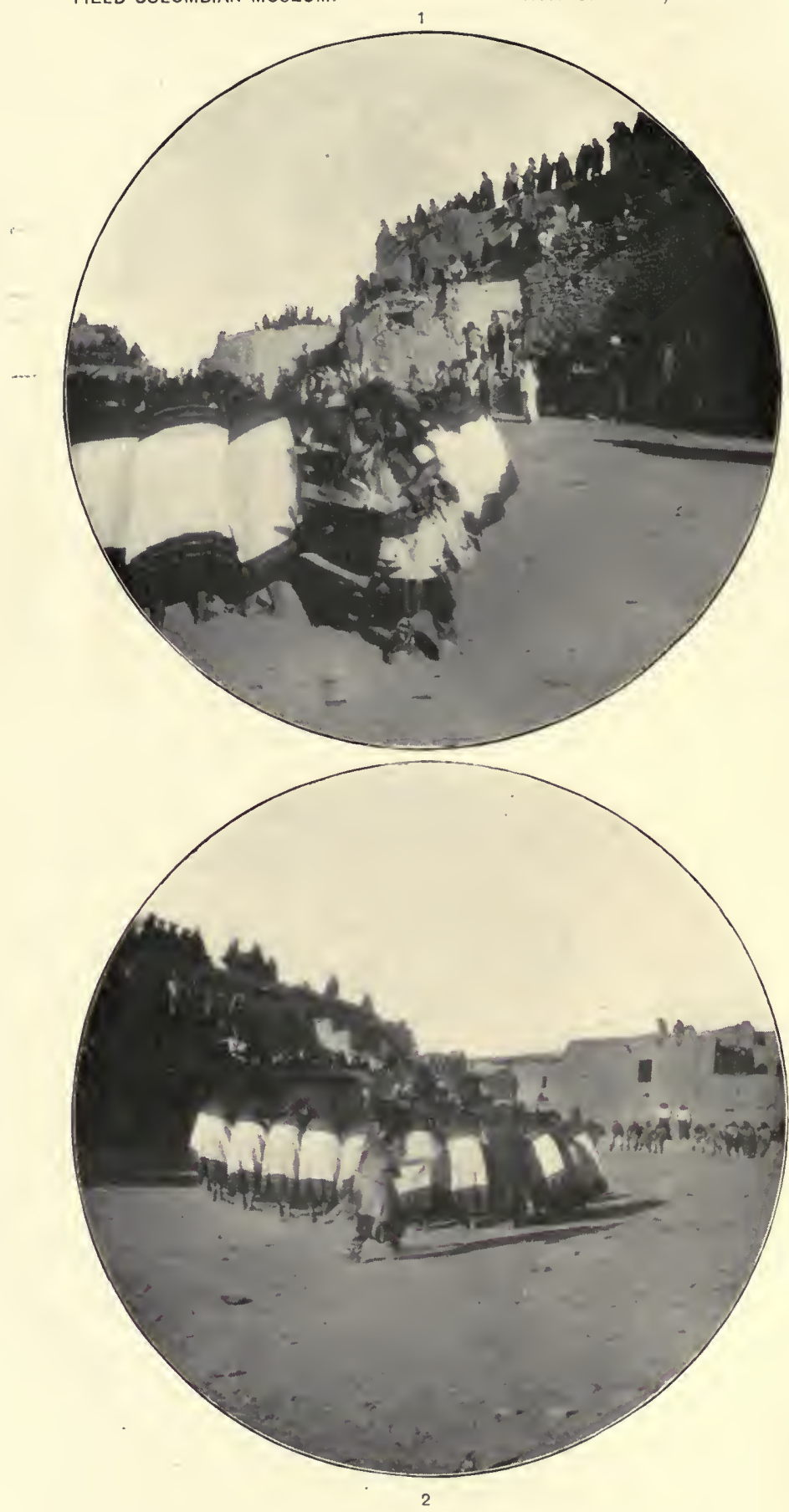


PL. XXIII. The Dance in Progress.

No. 1. One of the manas is seen in the act of throwing one of the prizes. While the mánas throw these presents the dance continues, the women not concerning themselves in any way whatsoever about the throwing of the prizes. In the background may be seen the uplifted arms of the spectators waiting for the descent of the prize thrown in that direction by the other mana. The spectators waiting for the prize of the mana seen in the foreground are not shown on the plate.

No. 2. One of the mánas getting ready to leave the plaza for the kiva. 



\section{THE LIBRARY \\ OF THE \\ UNIVERSITY OF ILLINOIS}


FIELD COLUMBIAN MUSEUM.

ANTHROPOLOGY, PL. XXIV.

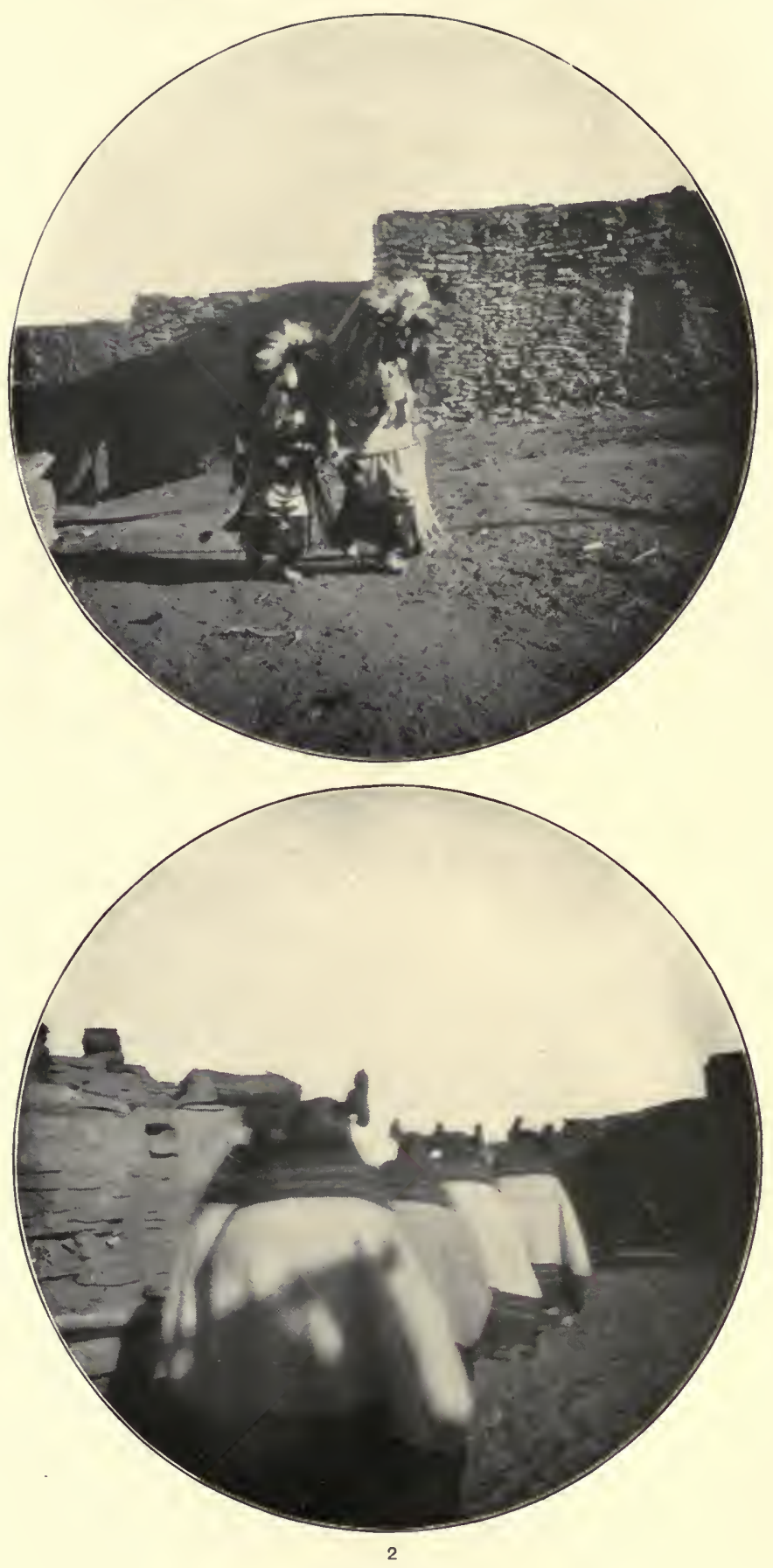


PL. xxiV. manas Returning to the Kíva.

No. 1. The two mánas on their way to the kiva.

No. 2. The rear end of the procession of dancers. Maidens participating in one of these dances always form the rear end of the line in going to and from the plaza. 


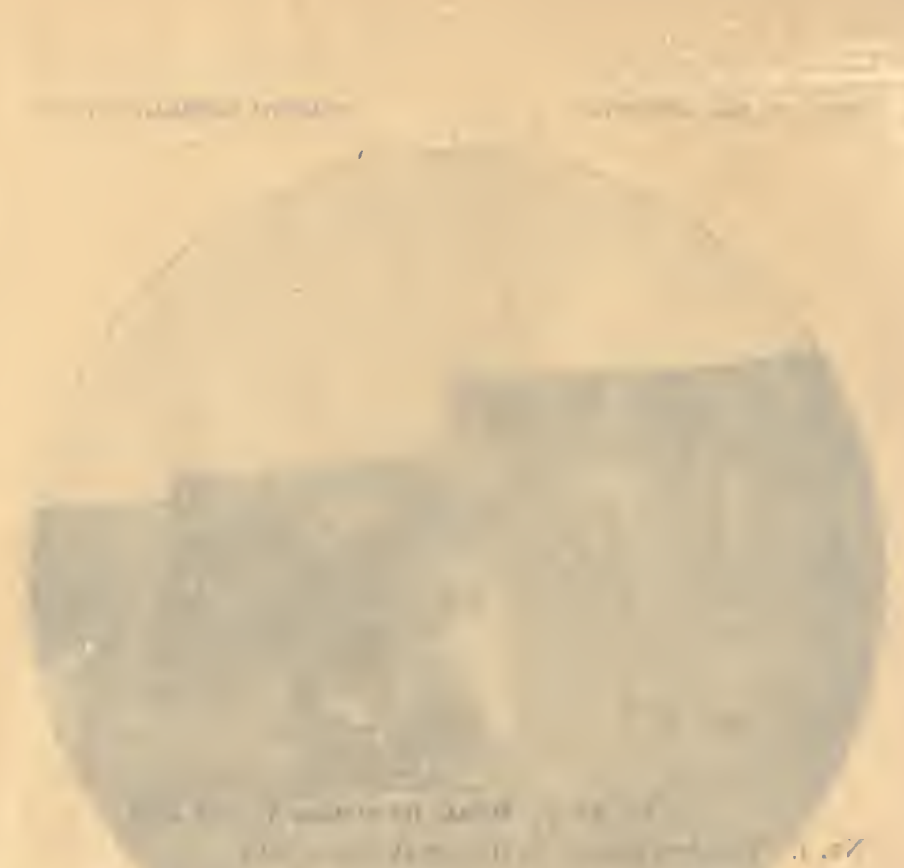

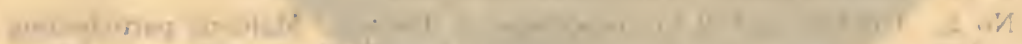

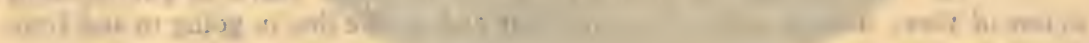
Chat ant

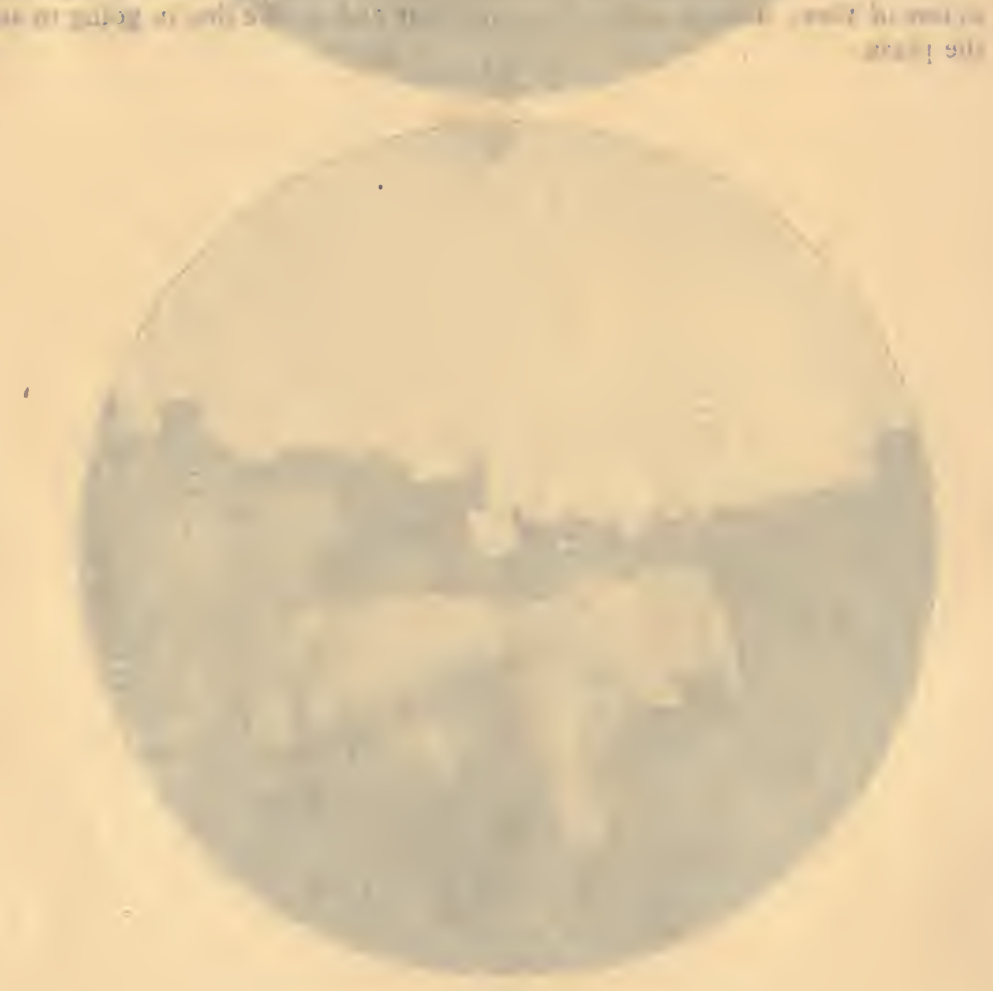




\section{THE LIBRARY}

OF THE

UNIVERSITY OF ILLINNIS 


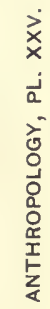
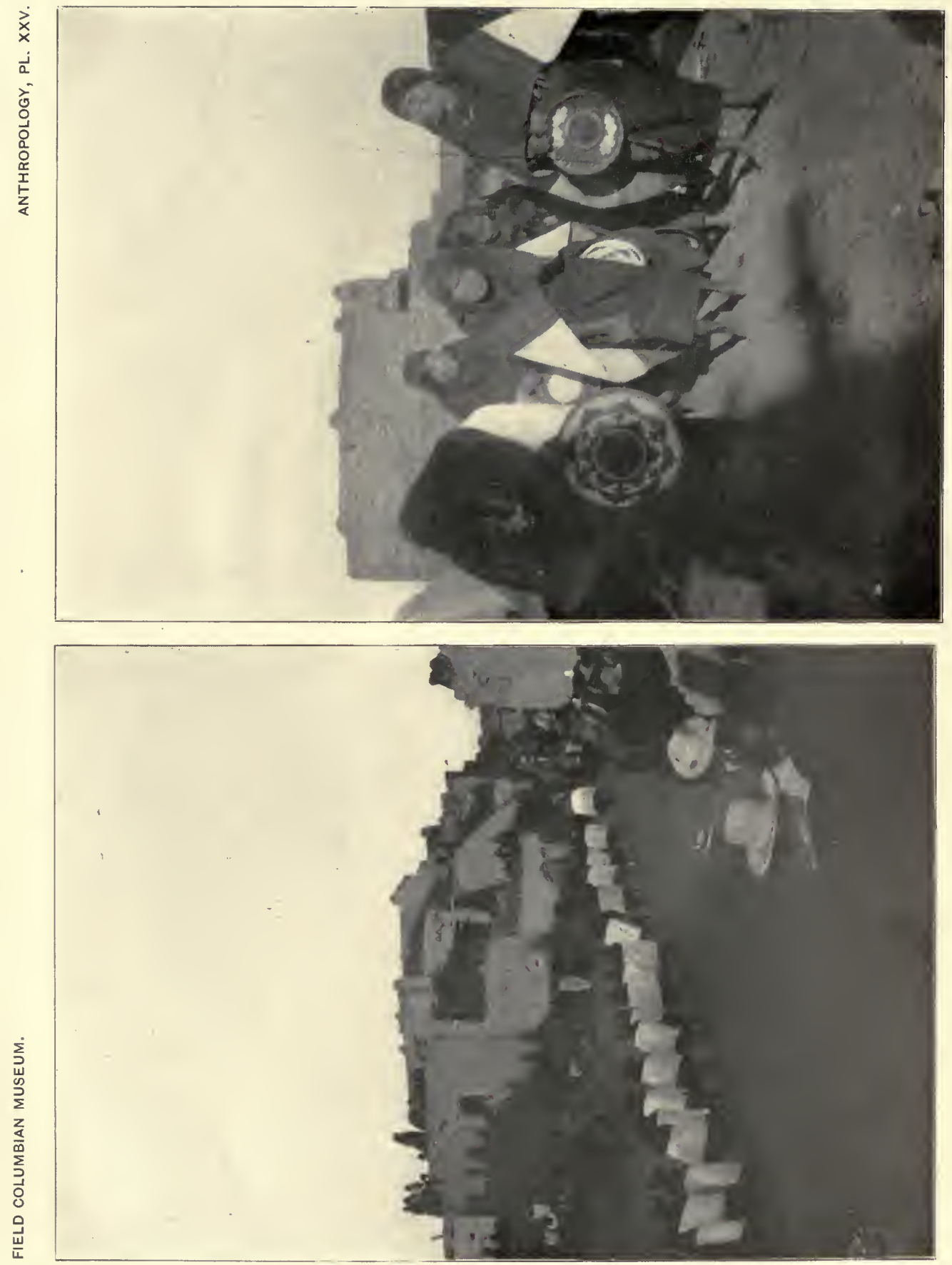
PL. XXV. The Dancers Returning to the Kiva.

No. I. The line of dancers, as they file from the plaza, on their way from the kiva.

No. 2. The dancers have arrived at the kiva. Ngösi is seen in the act of replacing the natsi at the south end of the kiva. 


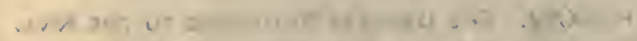

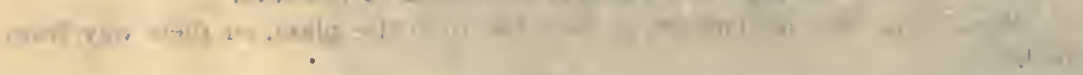

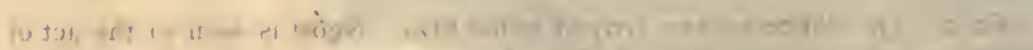

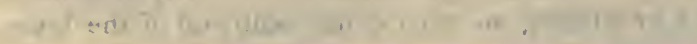

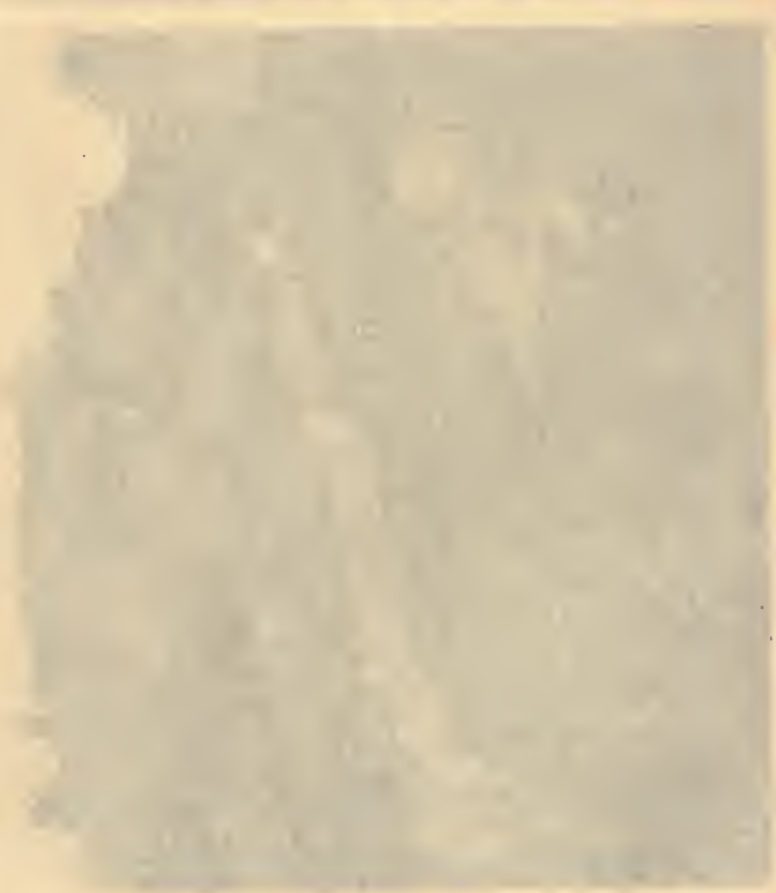


tinue this around the circle and finally into it. (See Pl. XXI.) Hereupon they open the bundle, which is the signal for a general commotion, and great shouting among the spectators, the male portion of whom rush from all sides to the circle (see Pl. XXII), tach one being eager to obtain one of the trays thrown by the mánas. (See Pl. XXIII.) These throw the trays in different directions, ${ }^{1}$ which keeps the crowd surging up and down from one side of the circle to the other. When the supply of prizes is exhausted the manas return to the kiva (see No. 1, Pl. XXIV), where they lay off their costume and rub off the paint. The dancers soon follow. (See Pl. XXV.) Ngơsi replaces the nátsi at the kiva hatchway (see No. 2, Pl. XXV), and all then enter the kiva. Here now the so-called náwohchi (discharming) of all the participants takes place. This I have witnessed only once. Ngôsi took from the altar a buzzard wing feather and from the fireplace a little ashes. All arranged themselves around the fireplace, each one also holding a pinch of ashes in the right hand. Ngosi then strewed a little ashes along the inside of the feather which she held in her left hand, whereupon all hummed the following náwohchi táwi (discharıning song), Ngðsi waving the feather slightly up and down to the time of the singing:

\section{DISCHARMING SONG.}

'To THE North.

Chíwiwitoyáhaiahai!

Chówiwitoyáhaiahai!

Shúkwiniñaqö,

Sikawicókota,

Macáyata akwáaha!

Chiwiwitoyáhaiahai!

Chíwiwitoyáhaiahai!

Shúhtawangqö,

Cakwáwicokota,

Macáyata akwáaha!

Chíwiwitoyáhaiahai!

Chíwiwitoyáhaiahai!

Shúhtatyaqö,

Paláwicokota,

Macáyata akwáaha!
Discharm!

Discharm!.

From the north,

Yellow buzzard,

With the wing!

To THE IVEST.
Discharm!
Discharm!
From the west,
Green (blue) buzzard,
With the wing!

To The South.
Discharm!
Discharm!
From the south,
Red buzzard,
With the wing!

${ }^{1}$ Before throwing the prize they run across the space within the circle, but in opposite directions, break througb the line of dancers, and then throw the objects. 
44 Field Columbian Museum-Anthropology, Vol. Vi., No. I.

To THE EAst.

Chíwiwitoyáhaiahai!

Discharm!

Chíwiwitoyáhaiahai!

Discharm!

Shúhhohopqö,

Qötcáwicokota,

Macáyata akwáaha!

From the east

White buzzard,

With the wing!

To the North-west (Above).

Chíwiwitoyáhaiahai!

Chíwiwitoyáhaiahai!

Shúongaqö,

Cöqömvicokota,

Macáyata akwáaha!
Discharm!

Discharm!

From above,

Black buzzard,

With the wing!

To the South-west (Below).

Chíwiwitoyáhaiahai!

Chíwiwitoyáhaiahai!

Shúatyaqö,

Macíwicokota, di

Macáyata akwáaha!

Chíwiwitoyáhaiahai!

Chíwiwitoyáhaiahai!
Discharm!

Discharm!

From below, Gray buzzard,

With the wing!

Discharm!

Discharm!

While singing the line "Chíwiwitoyáhai," at every stanza, Ngósi brushes with her right hand the ashes from the feather towards the hatchway, all the others throwing the pinch of ashes which they hold between their left thumb and index finger in the same direction, too, with a circling motion. Ngosi strews fresh ashes along the feather, the others take a fresh pinch from their right hand, and the same performance is repeated during the remaining five verses. After the last stanza has been chanted all beat the ashes from their hands, spit into their hands, rub them together, and finally rùb their bodies with them.

What is the object of this discharming rite? The Hópi believe that every secret fraternity and its paraphernalia possess its peculiar charm or influence, which is injurious to the initiated. The charm of the Snake Fraternity is a swelling which may occur on any part of the body; that of the Horn Fraternity, a distortion of the neck and face; that of the Oáqöl Fraternity, a peculiar swelling on top of the head, etc. Through this discharming rite, which takes place at the conclusion of every Hópi extended ceremony, and on numerous other occasions, such charm is supposed to be removed from the participants, so that after that they may again mingle with impunity with nonparticipants and in every-day life. This danger is considered to be 
THE LIBRARY OF THE UNIVERSITY OF ILLINOIS 


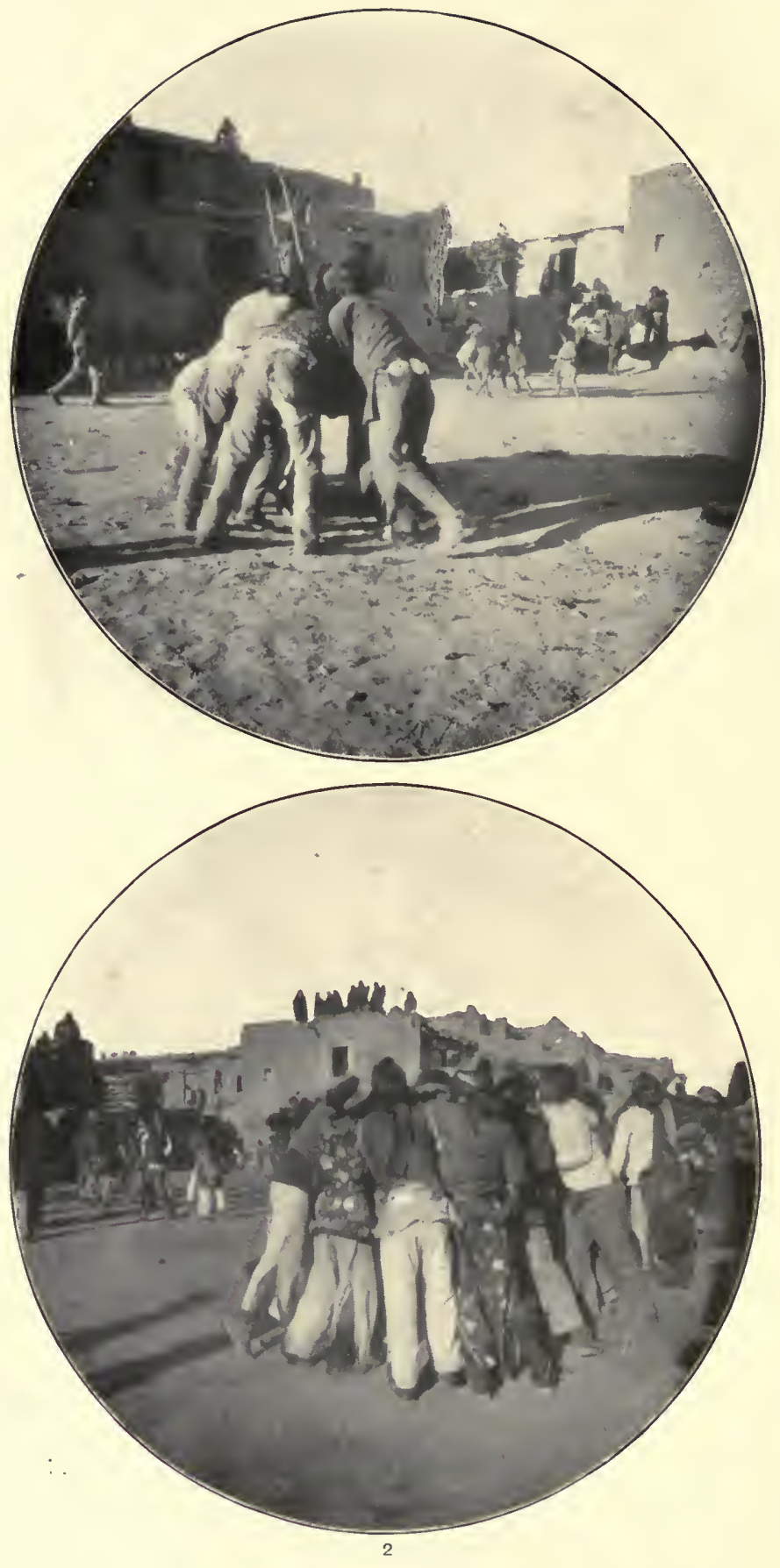


Pl. XXVi. Contesting One of the Prizes.

No. I. The wrangle begins.

No. 2. The wrangle continued. 


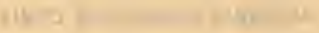

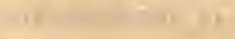

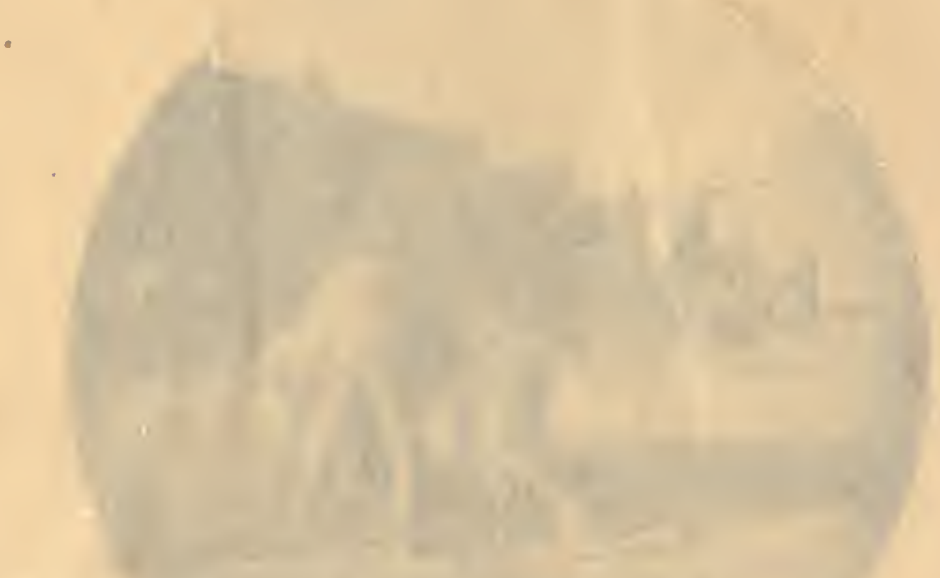

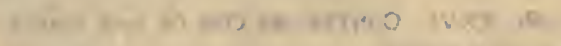
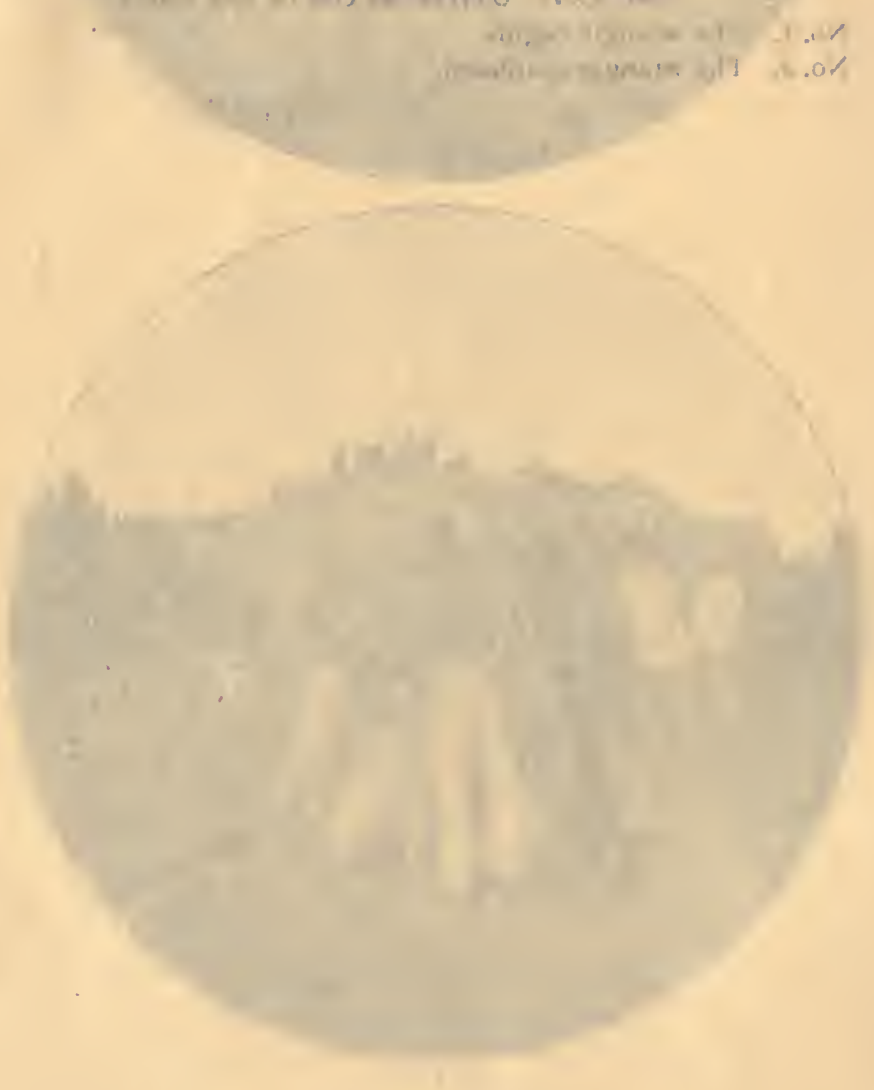


\section{THE LIBRARY \\ OF THE \\ UNIVERSITY OF ILLINOIS}



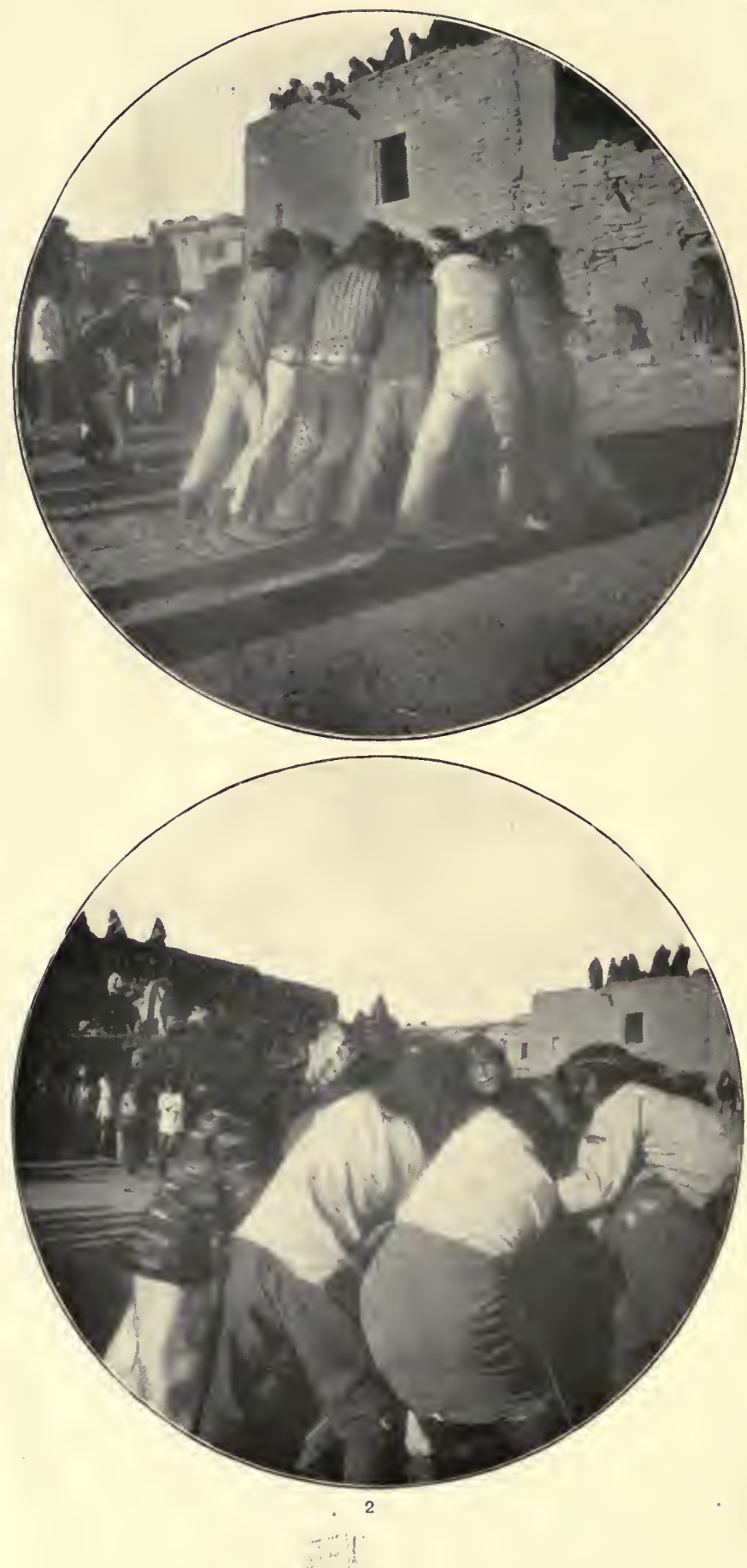
Pl. XXVII. The Prize Contest in Full Sway.

No. I. This snapshot view was obtained as the crowd of closely intertwined contestants were rushing across the plaza, being impelled by the forcible efforts of one or two of the contestants.

No. 2. The Climax. 


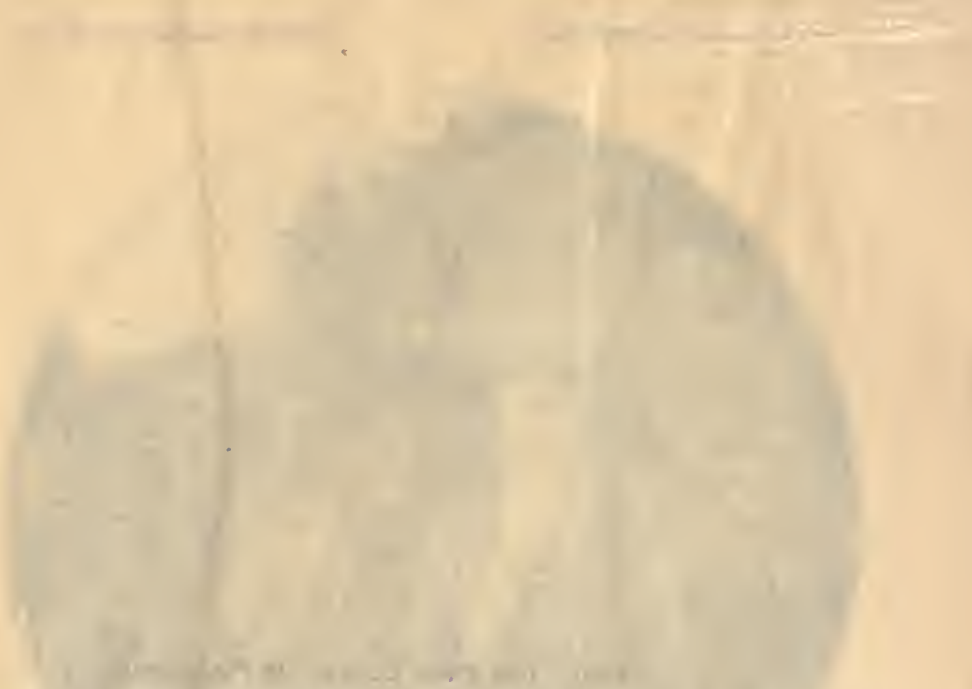

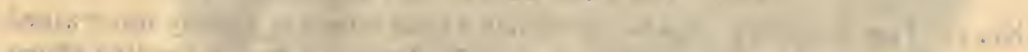

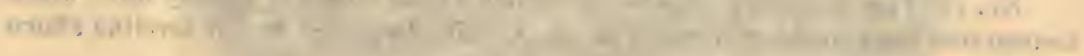

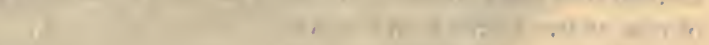
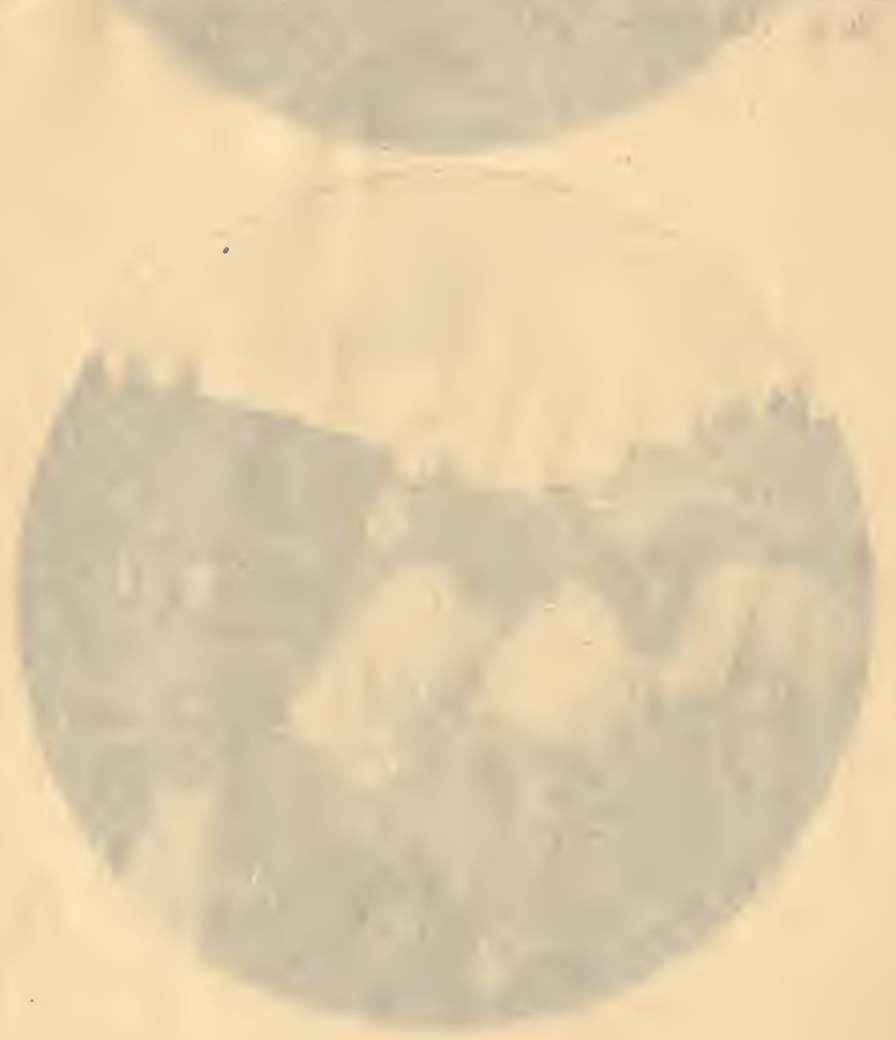
greater with regard to the altar paraphernalia, which no one can touch or even see without running the risk of being charmed, than with regard to the participants, who have come into contact more or less with others and with their homes during the ceremony. Should at any time any one in the village have a malady similar to the charm of any fraternity, the chief priest of that society is called to discharm the patient, which he does by singing the discharming songs of his society over the sufferer.

The discharming ceremony over, the morning meal is partaken of by most of the women in their homes, by the novices and a few of the older women in the kiva. The four women who held the netted gourd vessels during the dance take them with them and the water from them is emptied out as a prayer for rain in some of their fields. After breakfast all reassemble in the kiva, two other participants are decorated and dressed up, a fresh lot of trays is tied up, to which occasionally a watermelon, a piece of calico, a large round cake, a bowl, etc., is added ${ }^{1}$ and then another public performance takes place. It does not differ essentially from the one already described-only the four women have not now the netted gourd vessels. All have again trays, holding also a pinch of sacred meal in their hand.

Eight or ten such dances take place during the day. For each one, two fresh mánas are prepared, who may be either girls or women.

During the intervals between the dances the plaza is by no means deserted, as is usually the case in interrupted performances. One of the trays thrown last at the various dancers usually becomes the object of a spirited contention. First, two or three try to tear it from the winner. (See No. 1, Pl. XXVI.) Soon others take a hand in the wrangle, the number of ten swelling up to fifteen or twenty. (See No. 2, Pl. XXVI.) Sometimes this closely knit mass of humanity will remain for some time stationary at one spot, or at least nearly so. Then one or two specially strong contestants, who may have succeeded in getting hold of the coveted prize, or of one of these closely wedged in, will set the whole body of contestants in motion (see Pl. XXVII), so that it keeps moving, sometimes slowly, sometimes rapidly, from one part of the plaza to the other, until some become exhausted and are shaken off by the last, especially violent efforts of others, and finally one who has a specially good hold of the object or is particularly strong, remains victor. I have seen these contests last for thirty, forty, fifty minutes, and even as long as an hour and a quarter,

${ }^{1}$ On one occasion the women had included a large deseeded sunflower disk, which somewhat resembled a yucca tray, when it was hurled through the air, and the disgust of the men, when they found that they were deceived, caused a good deal of hilarity. 
46 Field Columbian Museum-Anthropology, Vol. Vi., No. I.

and an hour and a half, so that they continue while another dance is in progress. The contestants are panting and bathed in perspiration, their clothes are sometimes badly torn (see No. 1, Pl. XXVIII), and the tray, too, is sadly twisted out of shape. (SeeNo. 2, Pl. XXVIII.)

During the forenoon, while the dances are in progress on the plaza, the race for the two trays takes place down in the valley, as already described. .

In the intervals when the women are on the plaza, the chief priest dismantles the altar, tying the slabs in bundles and putting the smaller objects, such as the birds, cloud symbols, etc., into old jars. The small kaøbahos are distributed among the participants after the dance is over and before they leave the kiva. On one occasion I saw them placed into a blanket when the altar was dismantled; their final disposition I have never personally witnessed, but am told by numerous parties that they are either thrust between the carefully piled up cornears in the houses of the participants or are buried as prayer-offerings in their fields.

For the last dance, all the women rub some meal into their faces, and when the chief priest has finished asperging them on the plaza, he pours the water that remains in the medicine bowl into the little shrine on the plaza.

The eagle feathers and corn-ear from the nátsi are, I understand, put away with the altar paraphernalia; the nakwákwosis from the sprig. of cávi and the pedestal are thrown on the altar sand and swept up and carried out with it. The sprig itself is deposited somewhere by Ngôsi, but this has not been witnessed. 


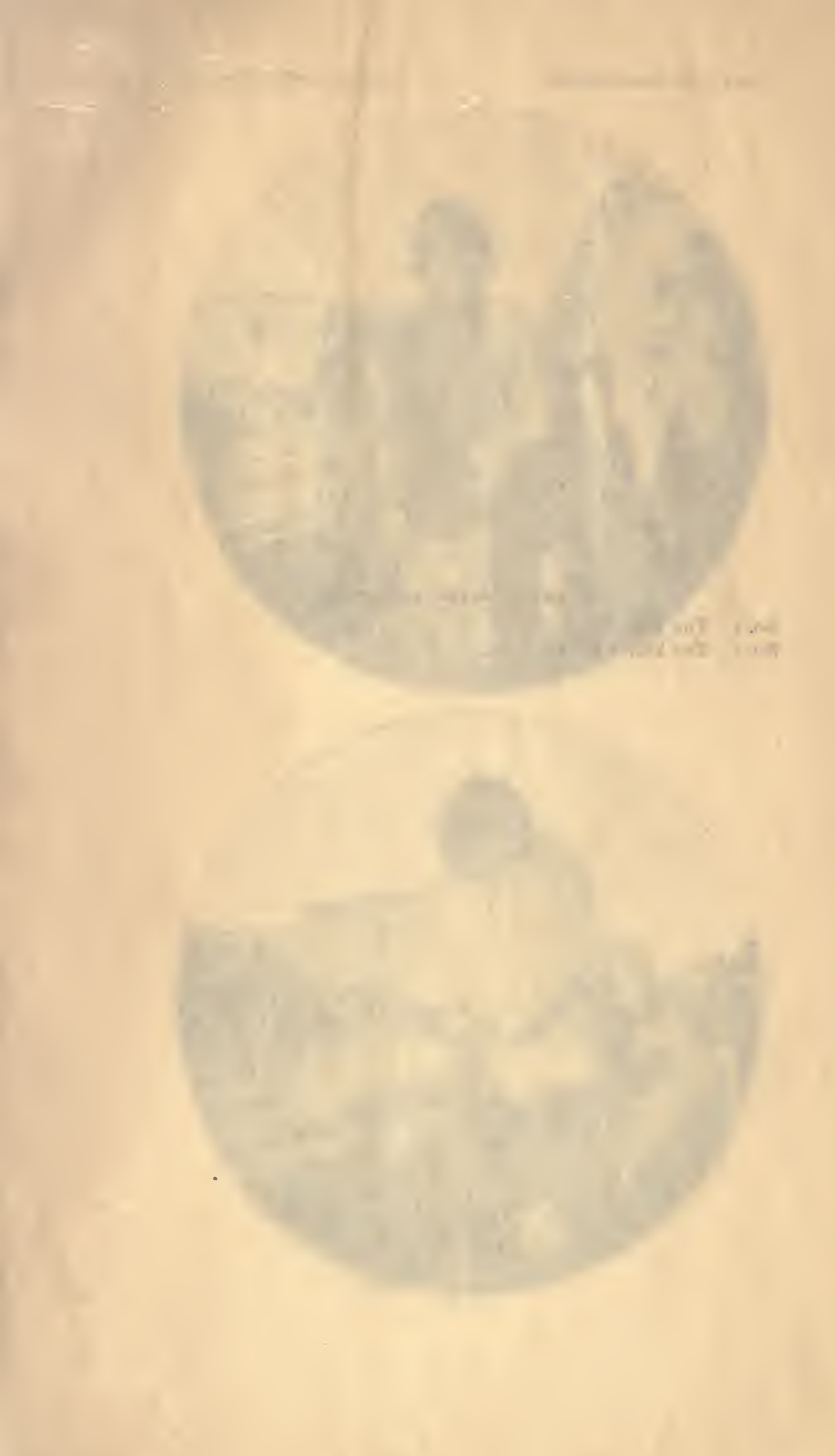




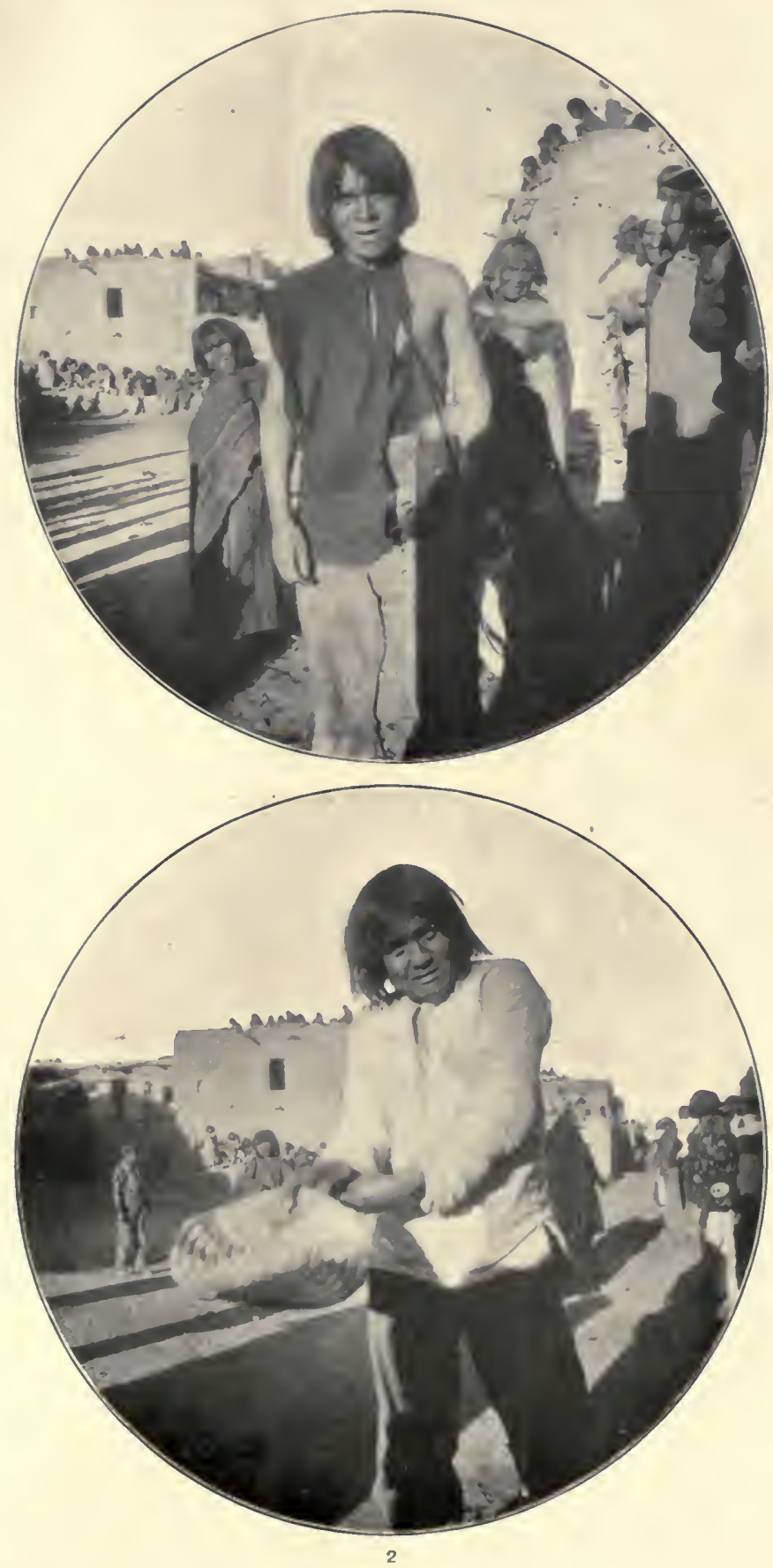


\section{THE LIBRARY \\ OF THE UNIVERSITY OF ILLINOIS}

